\title{
Hydrologic and Human Aspects of the 1976-77 Drought
}

GEOLOG ICAL SUR VEY PROFESSIONALA P ER 1130
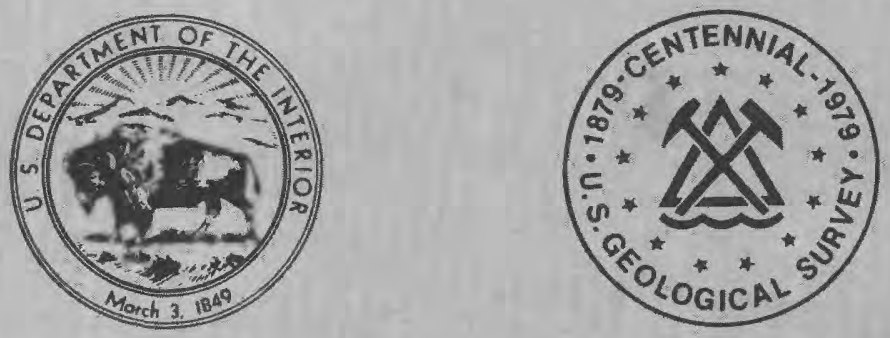


\section{Hydrologic and Human Aspects of the 1976-77 Drought}

By HOWARD F. MATTHAI

GE OLOGICA L S UR VEY PROFES I O N A L P A P E R 1130

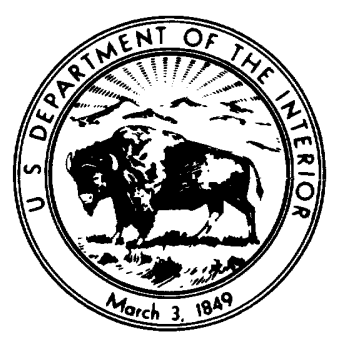

$\overline{\text { UNITEDSTATESGOVERNMENT PRINTINGOFFICE, WASHINGTON : } 1979}$ 


\section{UNITED STATES DEPARTMENT OF THE INTERIOR}

CECIL D. ANDRUS, Secretary

\section{GEOLOGICAL SURVEY}

H. William Menard, Director

Library of Congress number 79-600188

For sale by the Superintendent of Documents, U.S. Government Printing Office Washington, D.C. 20402

Stock number 024-001-03243-1 


\section{CONTENTS}

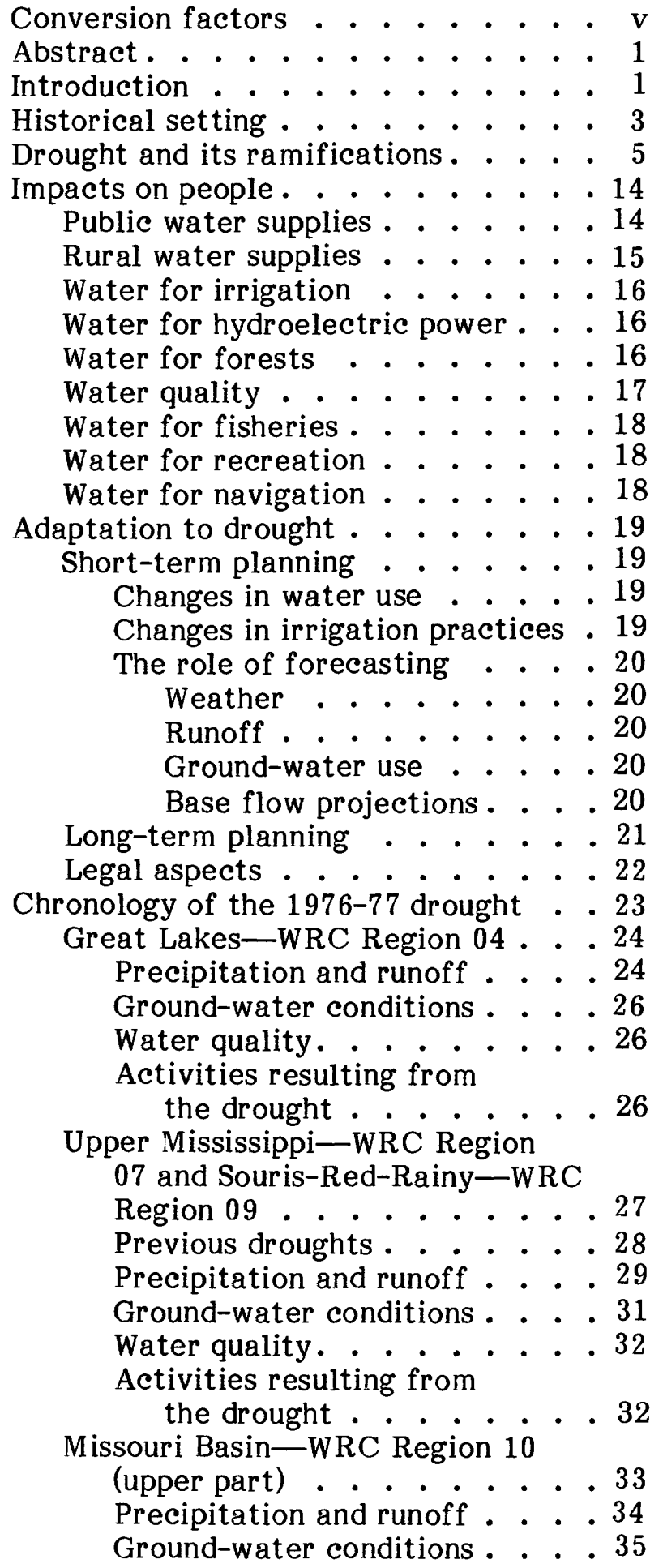

Water quality. . . . . . 36

Activities resulting from

the drought . . . . . . 36

Missouri Basin-WRC Region 10

(lower part) ....... 36

Previous droughts . . . . . 37

Precipitation and runoff . . . 37

Ground-water conditions . . . 38

Water quality. . . . . . 38

Activities from the drought . . 39

Arkansas-White-Red-WRC

Region 11 . . . . . . 39

Precipitation and runof f . . 39

Ground-water conditions . . . 41

Water quality. . . . . . . 41

Activities resulting from

the drought . . . . . . 41

Upper Colorado-WRC Region 14 . 41

Precipitation and runoff . . . 43

Ground-water conditions . . . 46

Water quality. . . . . . 46

Activities resulting from

the drought ....... 46

The Great Basin-WRC Region 16 . 47

Previous droughts . . . . . 47

Precipitation and runoff . . . 49

Ground-water conditions . . . 50

Water quality. . . . . . 51

Forests ......... 51

Activities resulting from

the drought . . . . . 53

Pacific Northwest-WRC

Region 17 . . . . . . 53

Previous droughts . . . . . 53

Precipitation and runof $\mathrm{f} . . .54$

Ground-water conditions . . . 58

Water quality. . . . . . 59

Forests . . . . . . . 59

The fishery. . . . . . . 59

Activities resulting from

the drought ...... 60

California-WRC Region 18... 61

Precipitation and runoff . . . 62

Ground-water conditions . . . 66

Water quality. . . . . . 67

Land subsidence . . . . . 69 
Hydroelectric power generation ...... 71

Forests .. . . . . . . 71

Activities resulting from

the drought ....... 71

Hawaii-WRC Region 20 . . . . 72

Previous droughts . . . . . 72

Precipitation and runoff . . . 73

Ground-water conditions . . . 73

Water quality. . . . . . 74

Activities resulting from

the drought . . . . . 74
The eleven other WRC Regions . 74

Precipitation and runoff . . . 74

Ground-water conditions . . . 75

Water quality. . . . . . 75

Activities resulting from

the drought . . . . . 75

Epilogue .......... 76

Summary . . . . . . . . . 77

A look to the future. . . . . . 77

Selected references . . . . . . 83

\section{ILLUSTRATIONS}

FIGURE 1. Map of the United States showing regions designated by Water

Resources Council . . . . . . . . . . . . . . . . 2

2. Graphs of low-flow frequency curves for six streams in areas

affected by the drought ..................77

3. Maps of United States showing number of months of deficient

streamflow. . . . . . . . . . . . . . . . . 8

4. Graph of water level decline caused by reduced natural

recharge during the drought ... . . . . . . . . . . . 10

5. Graph of fluctuations, of water level, 1960-77, in well 16/15-34N4

near Cantua Creek, 35 miles southwest of Fresno, Calif. . . . . . 11

6. Maps of United States showing values of the Palmer index on four selected dates in 1976 . . . . . . . . . . . . . . 12

7. Maps of United States showing values of the Palmer index on four selected dates in 1977 . . . . . . . . . . . . . 13

8. Photograph of stunted ears of corn caused by drought in Midwest . 17

9. Map of Great Lakes-WRC Region 04 . . . . . . . . . . . . . 25

10. Graph of monthly discharge of Fox River at Rapide Croche Dam, near Wrightstown, Wis. ................ . 27

11. Map of Upper Mississippi-WRC Region 07 and Souris-RedRainy-WRC Region 09 . . . . . . . . . . . . . 28

12. Photograph of parched soil in Iowa in 1976 . . . . . . . . . . 30

13. Map of Missouri Basin-WRC Region 10 (upper part) . . . . . . . 34

14. Map of Missouri Basin-WRC Region 10 (lower part) . . . . . . . 37

15. Map of Arkansas-White-Red-WRC Region 11 . . . . . . . . 40

16. Map of Upper Colorado-WRC Region 14. . . . . . . . . . . 42

17. Photographs of snow cover in Colorado Rockies

a. April 1976. . . . . . . . . . . . . . . . . 44

b. April 1977 . . . . . . . . . . . . . . . . . . . . . . 44 4

18. Map of the Great Basin-WRC Region 16. . . . . . . . . . . 48

19. Map of Pavant Valley, Utah showing change of water levels from March 1977 to March 1978. . . . . . . . . . 52

20. Map of Pacific Northwest-WRC Region 17 . . . . . . . . 54

21. Graph of water content of Columbia River basin snowpack

as a percentage of the April 1 average . . . . . . . . . . 55 
22. Photographs of snow cover in the Cascades, Washington

a. April 1976. . . . . . . . . . . . . . . 56

b. April 1977................... 57

23. Map of California-WRC Region 18 . . . . . . . . . . 61

24. Graph of water content of snowpack in California as a

percentage of the April 1 average . . . . . . . . . . . 63

25. Graph of monthly mean discharges for four selected drought

years, North Fork American River at North Fork Dam, Calif. . • . 64

26. Graph showing trends in streamflow at selected sites in

California, October 1975 to January 1978 . . . . . . . . 65

27. Photographs showing depleted conditions of water in storage in two reservoirs

a. $\quad$ Pardee Reservoir near Valley Springs, Calif., March 26, 1977 . 67

b. Shasta Lake near Redding, Calif., September 5, 1977 . . . . 67

28. Map of California showing ground-water level changes 1975-77 • 68

29. Map of Sacramento-San Joaquin Delta showing annual

maximum intrusion of salinity for selected years . . . . . 70

30. Map of Hawaii-WRC Region 20 . . . . . . . . . . 72

\section{CONVERSION FACTORS}

\section{Inch-pound}

acre

acre-ft (acre-foot)

board-foot

bushel

bushels per acre

$\mathrm{ft}^{3} / \mathrm{s}$ (cubic foot per second)

$\mathrm{ft}$ (foot)

gal/d (gallons per day)

bgd (billion gallons per day)

in. (inch)

mi (mile)

$\mathrm{mi}^{2}$ (square mile)
Multiply by

$4.047 \times 10^{-3}$

0.4047

$1.233 \times 10^{-3}$

$2.360 \times 10^{-3}$

35.24

0.0871

$28.32 \times 10^{-3}$

0.3048

$3.785 \times 10^{-3}$

3.785

25.40

1.609

2.590
Metric

$\mathrm{km}^{2}$ (square kilometer)

$\mathrm{hm}^{2}$ (square hectometer)

$\mathrm{hm}^{3}$ (cubic hectometer)

$\mathrm{m}^{3}$ (cubic meter)

$\mathrm{L}$ (liter)

$\mathrm{m}^{3} / \mathrm{hm}^{2}$ (cubic meter per square hectometer)

$\mathrm{m}^{3} / \mathrm{s}$ (cubic meter per second)

$\mathrm{m}$ (meter)

$\mathrm{m}^{3} / \mathrm{d}$ (cubic meters per day)

$\mathrm{hm}^{3} / \mathrm{d}$ (cubic hectometers per day)

$\mathrm{mm}$ (millimeter)

$\mathrm{km}$ (kilometer)

$\mathrm{km}^{2}$ (square kilometer) 



\title{
HYDROLOGIC AND HUMAN ASPECTS OF THE 1976-77 DROUGHT
}

\author{
By Howard F. Matthai
}

\begin{abstract}
The drought of 1976-77 was the most severe one in at least 50 years in many parts of the United States. Record low amounts of rainfall, snowfall, and runoff, and increased withdrawals of ground water were prevalent. The use of carry-over storage in reservoirs during 1976 maintained streamflow at near normal levels, but some reservoirs went dry or dropped below the outlet works in 1977. Carry-over storage in the fall of 1977 was very low.

Ground-water levels were at or near record low levels in many aquifers, hundreds of wells went dry, and thousands of wells were drilled. Yet no wide-spread deterioration of groundwater quality was reported. Water-quality problems arose in some streams and lakes, but most were localized and of short duration.

Water rationing became a way of life in numerous areas, and water was hauled in many rural areas and to a few towns. Water use was affected by legal agreements or decisions, some of which were modified for the duration of the drought, and by the inability of water managers to efficiently manage surface and ground waters as one resource under existing law.

There are still many drought related problems to solve and many challenges to be met before the next drought occurs. The advancement of techniques in many fields of endeavor in recent years plus ongoing, planned, and pro-posed research on drought and the risks involved are promising thrusts that should make it easier to cope with the next drought.
\end{abstract}

\section{INTRODUCTION}

A drought is primarily a natural event, but the consequences can be significantly altered by humans. The United States and other parts of the world have been afflicted intermittently by droughts from time immemorial; and one of them, a severe one, occurred in many parts of the United States in 1976 and 1977.

By the late winter of $1977-78$, enough rain and snow had fallen over much of the drought areas that the drought was considered by many people to be over. The wet period, however, may be only a brief interruption in an extended dry period. Historical records show that a wet period or year has occurred in the midst of a number of dry periods or years and, conversely, that dry years have occurred among groups of wet ones.

This report was prepared to document the drought of 1976-77 in the United States as a hydrologic event, how it affected humans, and how they reacted to it. Whether this report is a final report or an interim one depends mainly upon the weather in the future.

Many people have rather short memories in relation to droughts in the past, some have vivid recollections of experiences in their younger days, and a few have such active imaginations that their stories about past events have little relation to reality. To put the 1976-77 drought into context, several brief descriptions of previous droughts are included herein. The descriptions plus the references cited should give the reader some perspective on the latest drought.

Because there is a wide range in the factors related to climate, hydrology, topography, water use, and legal and economic conditions over the United States, some of the complex interrelations of these factors as they affect the drought or help to describe it are presented in the section, "Drought and its Ramifications."

The impacts of the drought on people are presented in a general way because many of them were similar. There was also a similarity in the actions taken by people in response to the drought.

Legal actions are quite prevalent if not almost customary in today's civilization. Drought-related activities provided circum- 




Figure 1. Map of United States showing regions designated by Water Resources Council.

stances that affected the well being of individuals or the responsibilities of public entities; therefore, legal actions were instituted that sought redress for losses related to the drought, and hearings were held to discuss interpretations of existing regulations and possible modifications of them. Some specific examples are given in the section, "Legal Aspects."

The Water Resources Council has divided the United States into 21 regions (fig. 1) which are major river basins or groups of river basins. Of the 21 regions, 18 were affected by the drought to some degree. The drought had minor effects in regions $05,06,12,13,15$, and 21 , and only localized effects in regions 02 and 03 . The chronology of the drought and its effects are described in detail for $10 \mathrm{WRC}$ regions, by region, and in general for the other 11 WRC regions later in this report. The regions affected by the drought are identified in figure 1 .

How people and agencies adapted to the drought and the beginnings of the recovery from the drought are also described.

The report concludes with a section, "A Look to the Future." The drought of 1976-77 caught many people in a state of complacency with respect to water supply and water use, but the problems encountered and the plans made to overcome them provided a valuable learning experience. Several plans have been proposed and others are in preparation to create means by which people can cope with a drought in the future in an orderly and less costly manner. Actions taken in response to such a crisis, whether locally or nationally, are not very efficient and often too late. The spring of 1978 is too early to know how many plans will be adopted and implemented, and another drought period will be needed before the success of plans can be evaluated.

The information in this report was obtained from numerous Federal, State, county, and municipal agencies, public utilities, the news media, and private individuals. The offices of the U.S. Geological Survey, Water Resources Division, provided data and information. 


\section{HISTORICAL SETTING}

The 1976-77 drought in the United States affected a larger part of the country more severely than other droughts in the 20 th century. Yet archaeologic and tree-ring evidence indicate that, meterologically and hydrologically at least, droughts in the past have been more severe and have lasted longer than the 1976-77 drought. In southern California, tree rings for the past 560 years show dry periods ranging from 6 to 40 years (Troxell, 1957) and periods that are predominantly wet last, on the average, 12.5 years, and those that are predominantly dry last about 14.5 years (Thomas and others, 1963e).

An extended drought occurred in the Southwest from about 1276 to 1300 . It is considered to be one of the prime reasons leading to the abandonment of the cliff dwellings and other community sites of several Indian groups in New Mexico and Arizona.

The more notable droughts in the 20th century are:

$\begin{array}{ll}1910 & \begin{array}{l}\text { drought in the Great Plains } \\ \text { drought in California }\end{array} \\ 1924-34 & \begin{array}{c}\text { drought in Oklahoma and the } \\ \text { Midwest (the Dust Bowl) }\end{array} \\ 1942-56 & \begin{array}{l}\text { drought in the Southwest } \\ \text { drought in the Midcontinent } \\ 1952-56\end{array} \\ 1961-67 & \begin{array}{l}\text { drought in the Northeastern } \\ \text { States }\end{array}\end{array}$

In 1910, the Dakotas, Nebraska, Kansas, and Oklahoma were hit by a drought. Precipitation in the Great Plains area was 71 percent of normal (Hoyt, 1938), but the area affected was large. Hoyt ranked the drought of 1910 as the third worst in semiarid States and as the seventh worst in humid States among the 15 worst droughts between 1880 and 1936 .

The period 1924-34 in California was predominantly dry. This drought acted as a catalyst in the development of the State Water Plan and the Central Valley Project. The drought started abruptly in 1924 , which was the driest year on record in the State until 1977. Runoff values for 1924 or for all or parts of the period 1924-34 were used as annual or multiyear criteria for the design of projects that required carry-over storage to provide firm low flows.

The "Dust Bowl" that resulted from the drought of 1930-40 in western Oklahoma, particularly in the Panhandle, and in eastern Colorado, and surrounding States is probably the drought that many people think of when a drought is mentioned. Now that the old-timers who lived through those days are not so numerous, the drought of 1976-77 may take its place as a conversation piece. Precipitation in Oklahoma was below normal in 7 of the 11 years, but only 3 of them had less than 85 percent of normal. The cumulative departure from the average for the 11 years was -19.79 in. which is almost the amount of rain that might be expected in 8 months, on the average.

Nearly half the Great Plains area had a desert climate in 1934 that produced arid and semiarid conditions in places that are normally subhumid. Seven weather observers in Oklahoma reported no rainfall during a calendar month in the summer of 1934, and rainfall was less than 0.25 in. at about 25 locations in Kansas. The deficient rainfall during the growing season from April through October was bad enough, but the area was the hottest in more than 40 years. High temperature records were set for June or July or for the April-August period. Monthly temperatures ranged from $2.5^{\circ}$ to $4.5^{\circ} \mathrm{F}$ above normal, and new daily high temperatures occurred at many places. Winds were frequent and strong enough to cause wind damage to structures.

During the previous decade, rainfall had been above average and sufficient to encourage farmers to plow up and plant land that was marginal without an ample water supply. With the cover of grass removed, the combination of deficient rainfall, the hot summer, and the wind easily converted the area into the "Dust Bowl." The parched soil was blown into drifts that buried what crops managed to sprout and made life miserable for the residents. About 50 million acres was affected at the height of the drought. It was this drought that caused an exodus from the farms in the stricken area and that was the impetus for soil conservation programs and better farming methods.

An interesting perspective on the "Dust Bowl" is that though it was certainly dusty, there have been more recent periods of drought in Oklahoma that meterologically and hydrologically were more severe. Precipitation in 1956 in Oklahoma, New Mexico, and Kansas was 35 percent of normal, and the average flow of the Washita River near Durwood, 
HYDROLOGIC AND HUMAN ASPECTS OF THE 1976-77 DROUGHT

$95 \mathrm{mi}$ south of Oklahoma City, Okla., for the 15-year period 1958-72 was only 70 percent of that for the 11-year period 1930-40. The improved farming practices and other factors reduced the impact on the public so that the more recent droughts received less notoriety, but losses still ran into billions of dollars.

The drought of 1942-56 in the southwestern United States is documented in a series of Geological Survey Professional Papers, Nos. $372 \mathrm{~A}$ through $372 \mathrm{G}$, by Gatewood or Thomas and other co-authors. The effects of this drought in an arid area fluctuated during the period at many localities, but it was severe enough that 282 counties in three states, mainly in Texas, plus all of Arizona and New Mexico and most of Utah were declared disaster areas.

Nace and Pluhowski (1965) reported that the rare occurrence of a succession of drought-producing meteorologic events during 1952-56 caused critical water deficiencies in much of the southern half of the nation. The accumulated precipitation deficiencies during the 5-year drought period, expressed in percentage of the average precipitation for 1 year, ranged from 25 to 225 percent. Lowflow frequency data for eastern Kansas indicate that the drought had a recurrence interval of more than 50 years. Statistical studies of long-term precipitation records for the southern Great Plains indicate that drought of equivalent severity has a recurrence interval of about 140 years in parts of the area. Ground-water levels declined steadily in much of the Midcontinent, and levels were reduced by tens of feet in some places. The decline in water supplies caused considerable financial loss and many personal hardships.

The 1961-67 drought in the Northeast was the longest and most severe in the history of the region, and it affected human activities mainly by its impact on water resources related to agriculture and water supplies (Barksdale and others, 1966). The Water Resources Council (1966) estimated that in the Northeast a drought of this duration occurs, on the average, once in about 160 years. Though drought conditions eased at different times in different parts of the Northeast, the drought was not over until the spring of 1967.

At least four of the six definitions of droughts suggested by the World Meteorological Organization (see p. 5 ) are applicable to each of the droughts briefly described above. Meteorologically, absolute amounts of precipitation were deficient for specific durations. Climatologically, precipitation, expressed as percentages of normal values, was significantly less than 100 percent. Atmospheric conditions, namely wind, relative humidity, and temperature, were contributing factors in causing the Dust Bowl. Agriculturally, soil moisture was reduced or depleted and the growth of vegetation and crops was hindered. Hydrologically, stream flows and ground-water levels were low and storage in lakes and reservoirs was reduced. In some areas, watermanagement practices had not progressed enough to provide integrated water-supply systems and surface or subsurface storage to equalize the water supply seasonally or from year to year.

The reader must remember that construction equipment used to build surface structures, well-drilling equipment and methods, and pumps were not as advanced 40 or 50 years ago as they are today. Hence, water management's ability to deliver water or develop ground-water supplies during the earlier droughts should not be judged solely by today's standards. Also, farm practices have improved, and hardier corn, wheat, and other crops have been developed since the 1930's; therefore, better production can be achieved now under drought conditions. All these developments and improvements make it easier to adapt to a drought now. Therefore, the perceived severity of a drought also depends on how well adaptations work.

In the context of a meteorological drought and using the seasonal (July 1 to June 30 ) precipitation at San Francisco, Calif., as an example, there have been four periods prior to 1976 when precipitation was below average for several years in succession. These periods are tabulated below along with the average deficiency per season and the total deficiency, as well as similar data for the period 1974-77.

$\begin{array}{rccc}\text { Period } & \begin{array}{c}\text { Number } \\ \text { of } \\ \text { years }\end{array} & \begin{array}{c}\text { Deficiency } \\ \text { (inches } \\ \text { per year) }\end{array} & \begin{array}{c}\text { Total } \\ \text { deficiency } \\ \text { (inches) }\end{array} \\ 1897-1904 & 7 & 3.74 & 26.20 \\ 1927-1934 & 7 & 5.18 & 36.25 \\ 1946-1950 & 4 & 5.04 & 20.14 \\ 1958-1966 & 8 & 5.25 & 42.03 \\ 1974-1977 & 3 & 9.83 & 29.49\end{array}$


The average deficiency for $1974-77$ is close to twice the rates of the previous droughts listed above, and the total deficiency of $29.49 \mathrm{in}$. is 81 percent of that from 1927-34 and 70 percent of that from 1958-66; yet it developed in just 3 years rather than in 7 or 8 years.

\section{DROUGHT AND ITS RAMIFICATIONS}

Numerous definitions of drought have been proposed and used by prominent individuals and organizations, yet only the very generalized definitions have much of a relation to the drought of 1976-77. A precise definition is not practical because a drought is the result of many complex factors acting on and interacting with the environment.

Among the natural factors are the climate of an area; the antecedent conditions as exemplified by the amounts of soil moisture, rain, and snow; the distribution of rain and snow in time and space; water-table levels during the drought; water quality; and soil types.

Human factors include the degree of development of water storage and distribution systems; the number, locations, and depths of wells; the patterns of water use and per capita consumption; the legal aspects relating to property rights, project operating rules, waterquality standards, and service contracts; economic considerations; and many more.

Therefore, a definition of a drought must be tailored to the conditions in an area at a given time. Even so, the result is a general definition. A drought may be defined as a condition where and when the water supply is deficient enough and for a long enough time to damage the growth of vegetation, industrial production, or domestic activities (J. S. Cragwall, Jr., written commun., 1977). Nace and Pluhowski (1965) mention the concept that a drought occurs wherever there is less water than the amount to which people have become accustomed. [Emphasis by writer.]

The Worla Meteorological Organization has defined six types of drought as follows (Subrahmanyam, 1967):

1. Meteorologic drought-defined only in terms of precipitation deficiencies in absolute amounts, for specific durations.

2. Climatological drought-defined in terms of precipitation deficiencies, not in spe- cific quantities but as a ratio to mean or normal values.

3. Atmospheric drought-definitions involve not only precipitation, but possibly temperature, humidity, or wind speed.

4. Agricultural drought-definitions involve principally the soil moisture and plant behavior, perhaps for a specific crop.

5. Hydrologic drought-defined in terms of reduction of streamflows, reduction in lake or reservoir storage, and lowering of ground-water levels.

6. Water-management drought-this classification is included to characterize water deficiencies that may exist because of the failure of water-management practices or facilities such as integrated water-supply systems and surface or subsurface storage to bridge over normal or abnormal dry periods and equalize the water supply through the year.

Each type is rather restrictive and by definition describes only one part of a complex whole.

Also, the kinds of drought enumerated by the World Meteorological Organization may occur sequentially, or overlap, or be combined in several ways. For example: A small amount of precipitation, a meteorological drought, over a long enough period will become a climatological drought as the precipitation will be a small percentage of normal. In turn, streamflow and storage in reservoirs and underground will be reduced to create a hydrologic drought which brings on problems of distribution and use which is a water-management drought.

In humid regions where rainfall normally occurs frequently during the growing season, a drought effect on nonirrigated agriculture can be achieved after only a few days of hot, dry weather. J. C. Hoyt (1938, p. 2) stated:

In general, however, in humid and semiarid states there are no serious drought effects unless the annual precipitation is as low as 85 percent of the mean; that is, unless there is an annual deficiency of 15 percent or more.

Hoyt also mentioned that the above criterion has shortcomings because it does not consider the effects of temperature and the 
distribution of precipitation nor that some areas can withstand large variations in precipitation whereas other areas cannot. Other hydrologists have found that the criterion of a 15 percent annual deficiency is meaningless if applied to desert areas where the mean annual precipitation does not exceed 5 inches because precipitation in many years is less than 85 percent of the mean and a drought implies a large departure from the norm.

In arid or semiarid areas, water deficiencies are chronic. Irrigation is necessary for most agriculture, and metropolitan areas-Los Angeles, San Diego, and San Francisco for example-also depend upon imported water for domestic, municipal, commercial, and industrial supplies. Therefore, drought conditions can be experienced where and when the demand exceeds the supply.

Hydrologists use analyses of low-flow frequencies to "define" a hydrological drought on an annual basis. If the actual low flow of a natural stream for a selected number of days has a small probability of occurrence then one can conclude that a drought, in a hydrologic sense, is in progress. Both the number of days and the level of probability considered to be an uncommon event are arbitrary.

Low-flow frequency curves have been determined from long-term records for six streams representing different areas affected by the drought in 1976-77. Frequency curves for selected numbers of consecutive days have been plotted in figure 2. Also, the discharges for 1976 and 1977 and the minimums of record are plotted.

In figure $2 \mathrm{a}$, the probability that the minimum average discharge for 30 consecutive days in a given year will be less than $26 \mathrm{ft}^{3} / \mathrm{s}$ is 0.10 (Point $X$ ). Because the recurrence interval, which is the average number of years between events, is the reciprocal of the probability, the flow will be less than $26 \mathrm{ft} 3 / \mathrm{s}$ at intervals averaging 10 years. In 1977 , the $30-$ day minimum discharge was $13 \mathrm{ft} 3 / \mathrm{s}$ which has a probability of 0.005 or a recurrence interval of 200 years. Because frequency curves are most reliable in the vicinity of the mean, a probability of 0.5 , probabilities determined near the extremes should be considered only as reasonable estimates, not exact probabilities.

The low-flow frequency curves and the flows in 1976 and 1977 at the six locations are not directly comparable. Differences may be caused by chance, by different basin characteristics, by different temperatures and precipitation at various times, or by combinations of these factors. However, several interesting conclusions can be made.

1. The North Fork American River at North Fork Dam, 31 mi northeast of Sacramento, Calif., and the Beaver River near Beaver, $48 \mathrm{mi}$ northeast of Cedar City, Utah had record minimum flows in 1977 at all numbers of consecutive days selected. Probabilities were roughly 0.01 to 0.005 , or the recurrence intervals are in the 100 to 200 year range.

2. Flows of the Sturgeon River near Sidnaw, $90 \mathrm{mi}$ northwest of Escanaba, Mich., for periods up to 183 days had probabilities equivalent to recurrence intervals greater than 200 years. The probabilities are from long extrapolations of the frequency curves and should be considered only as estimates. That the very low flows of the Sturgeon River are extremely rare events can be substantiated by the combination of two natural events. The drought in 1976 reduced the summer and fall flows to a new record low just slightly more than half the previous low flow of record. Then the extremely cold winter struck the area, and flows remained low until the latter half of March 1977. Thus the lowest 183-day period started on July 23, 1976 and ended on January 21, 1977.

3. Flows of the other three streams in other years were significantly less than in 1976 or 1977 though none of them had probabilities less than 0.012 , about an 80-year recurrence interval.

4. Record low flow for the entire year was the damaging feature related to the drought. Records for low annual flows were set at four of the six streams, and the recurrence intervals are in the $100-$ to $170-$ year range.

Whipple (1966) derived relations between the duration of a drought, in years, versus the probability of occurrence for five streams from Illinois to New Mexico and for three streams in Massachusetts. The relation curves are nearly alike for durations of 4 years or longer. On the basis of this small sample, the probability of a drought lasting 4 years is 

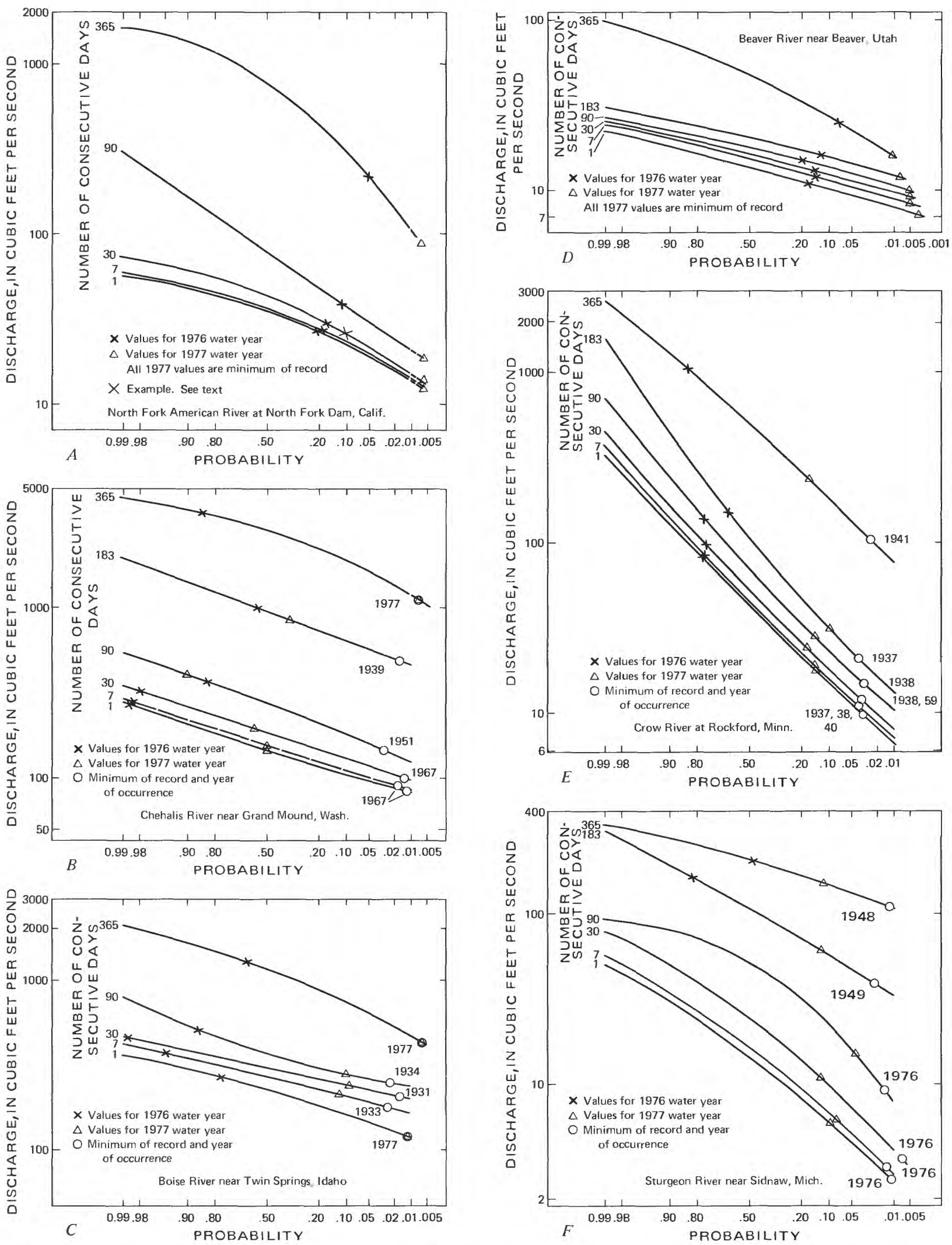

Figure 2. Low-flow frequency curves for six streams in areas affected by the drought. 
about 0.02 and that for one lasting 6 years is about 0.01 . The probability of a 2-year drought is in the range from 0.03 to 0.05 .

A factor related to the probabilities of low flows is the duration of low runoff. The number of months that streamflow was deficient is shown in figures $3 \mathrm{a}, 3 \mathrm{~b}$, and $3 \mathrm{c}$ during $12-, 18-$, and 23-month periods starting in February 1976. Monthly streamflow is deficient when it is within the lowest 25 percent of record for the month. See figure 10 as an example.
A month or two of deficient streamflow, or even 3 or 4 months in some areas, will not be a very serious hydrologic drought, particularly if the months are not consecutive.

The number of months of deficient streamflow does not indicate how many of them were consecutive nor when they occurred; but a hydrologic drought is evident because when 8 to 11 months out of 12 or 16 to 22 of 23 months are deficient, many of the months are consecutive and occur during the growing

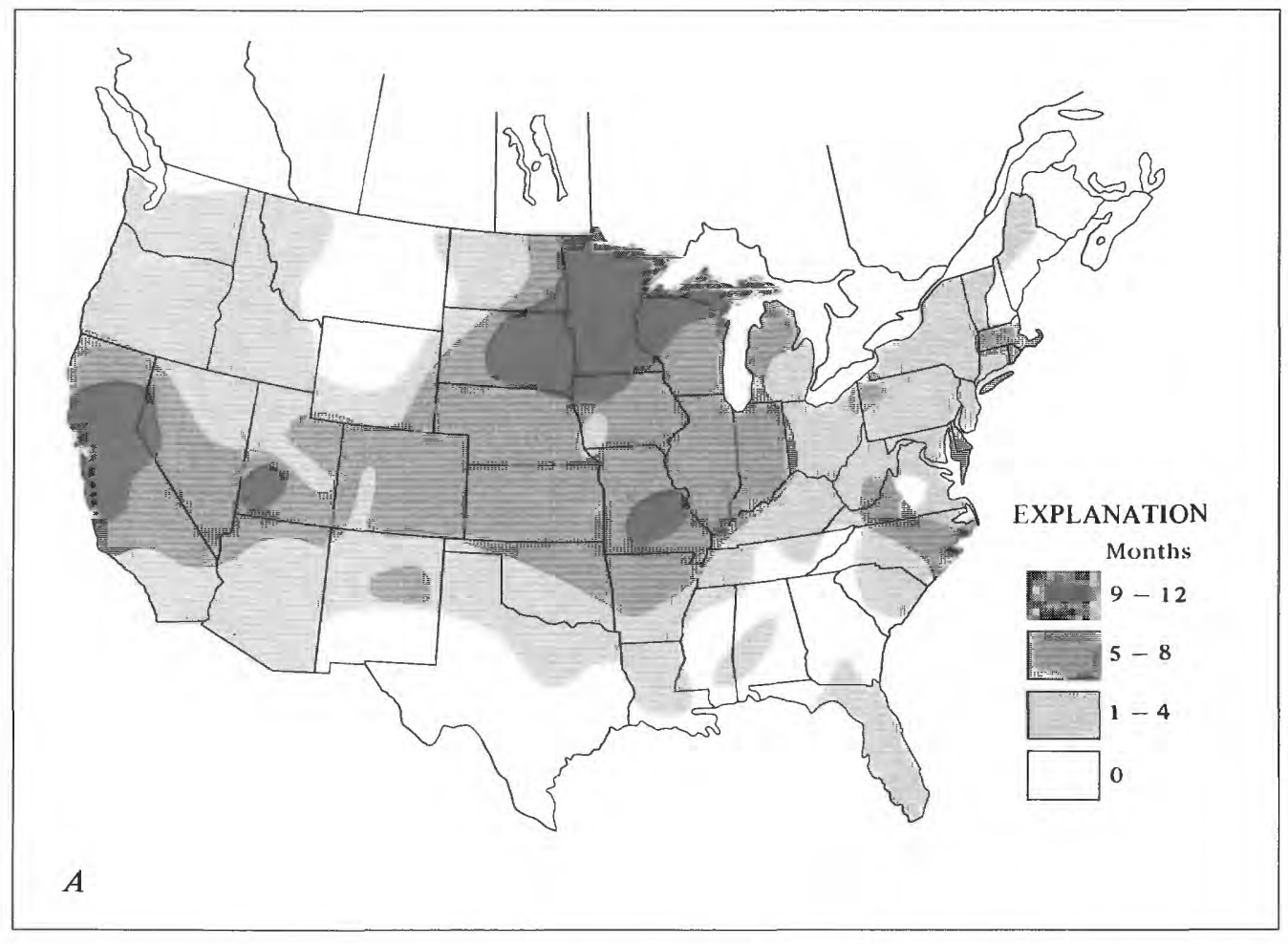

Figure 3. Maps of the United States showing 

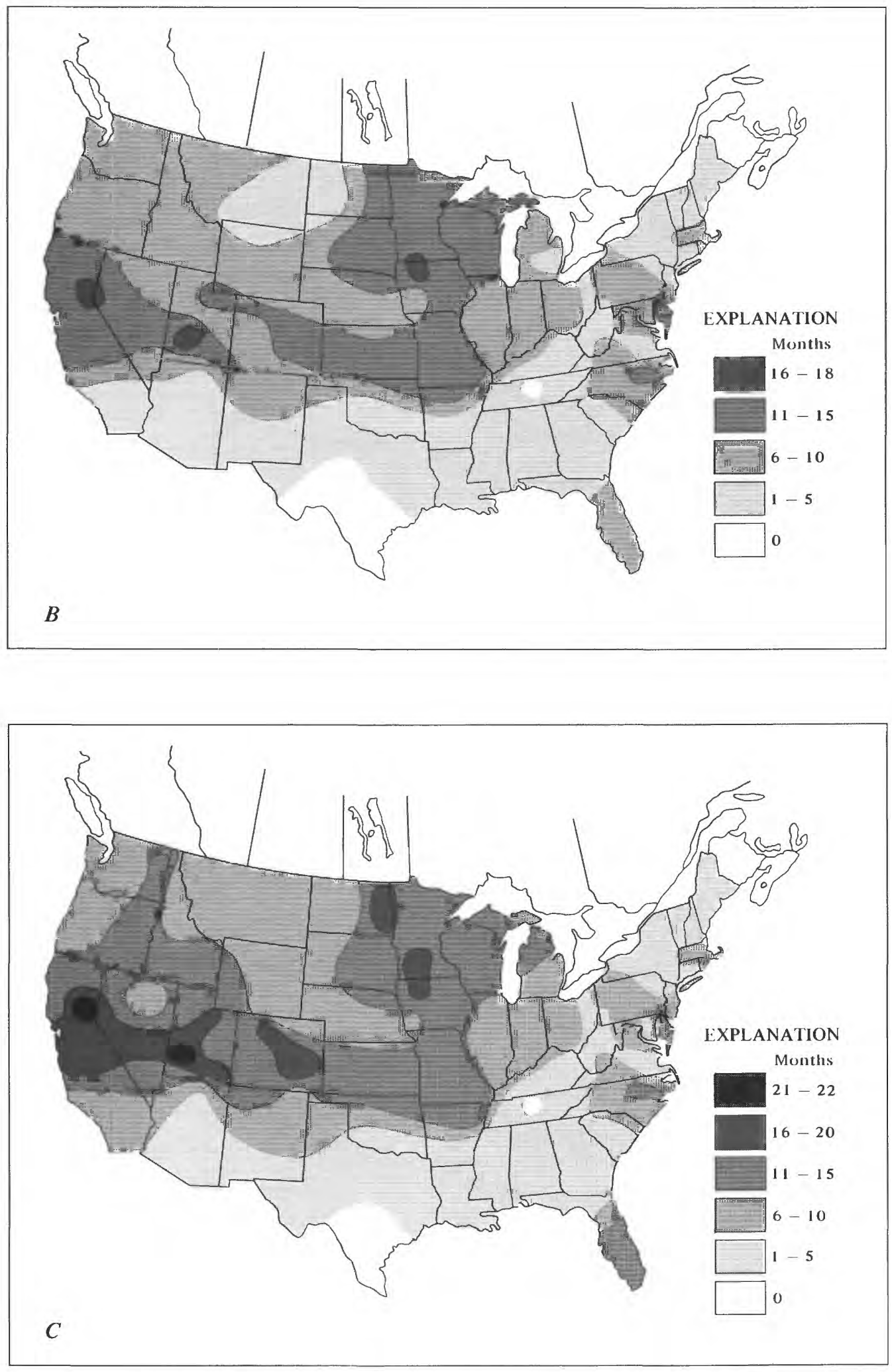

number of months of deficient streamflow. 
season. These conditions are depicted in a general way by the patterns in figure 3 .

Another way to recognize a drought is to compare ground-water levels and rates of decline with historic records. When precipitation is below normal, natural recharge is less, and ground-water levels may drop. This response is usually slow; that is, 2 or more years may pass before the effect of reduced recharge is evident in a given well. The major problem in trying to quantify this effect is that the water level in the vast majority of wells is affected by pumping in the vicinity, and any response to a change in recharge is masked by the fluctuations caused by the pumping.

One observation well that registers the water-table level in the Snake River basin about $130 \mathrm{mi}$ east of Boise, Idaho is not affected by pumping or return flows from irrigation. The hydrograph for this well is plotted in figure 4, and the decline of the water surface because of reduced natural recharge is clearly shown. The normal rise of 1.3 to $1.7 \mathrm{ft}$ usually between October and May was only $0.45 \mathrm{ft}$ in the winter of 1976-77. And the annual decline, which had ranged between 1.0 and $2.2 \mathrm{ft}$, was $2.9 \mathrm{ft}$ in 1977 .

If ground-water use increases to offset deficiencies in the surface-water supply, the rate of decline accelerates, and shallower wells may go dry. The magnitude of the effect of increased pumping is illustrated in figure 5 for a well in the Central Valley of California. The seasonal fluctuations from pumping are

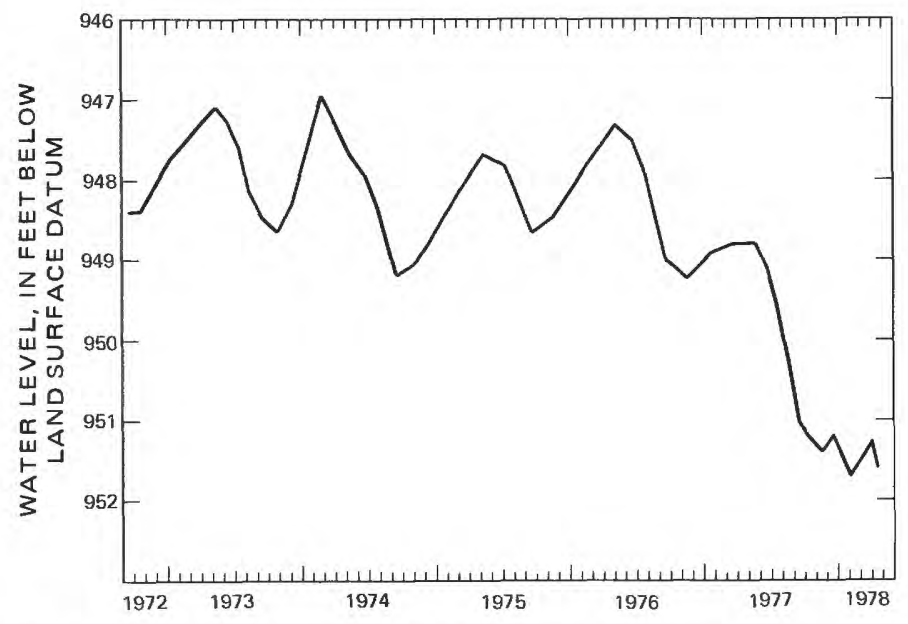

Figure 4. Water level decline caused by reduced recharge during the drought. Well is in the Snake River basin 130 miles east of Boise, Idaho. superimposed on a rising trend that started in 1968 when water was first imported to the area and pumping was reduced. The water level prior to the importation reached an all time low of $618 \mathrm{ft}$ below land surface in 1967 . Water-level records on this well have been obtained since 1960 when the level was $495 \mathrm{ft}$ below land surface. The decline of $123 \mathrm{ft}$ was caused by the overdraft during the 7 years, 1961-67. In the ensuing 9 years the water level rose $266 \mathrm{ft}$, but in only 8 months in 1977 the increased pumping lowered the water level $165 \mathrm{ft}$ which is 62 percent of the rise in just 7 percent of the time or 1.3 times the decline in the 7 years prior to the importation of water.

Still another indication of drought conditions is a deterioration of water quality. Both surface water and ground water are subject to changes in quality when new stresses are applied to a water system during a drought, and in most cases the change is for the worse.

Reduced freshwater flow into an estuary usually allows the saltwater to encroach farther than normal into the estuary or even into the tidal reaches of the tributary streams. The Sacramento-San Joaquin Delta in California was one of the areas that had problems because of saltwater encroachment.

In some coastal areas, freshwater is injected into wells near the ocean to establish a hydraulic gradient that will prevent saltwater intrusion into the aquifer. During a drought, there may not be enough freshwater available to maintain the freshwater-saltwater interface at an acceptable position, and salinity problems might develop.

Lower streamflows during a drought usually mean higher water temperatures with adverse effects on fish and greater aquatic growths that cause increased eutrophication of water bodies. Special releases and spills at dams on the Columbia River were made in 1977 to help preserve the fishery resource during the $\mathrm{mi}-$ gration period.

The National Oceanic and Atmospheric Administration, Environmental Data Service, uses a drought index developed by W. C. Palmer (1965) to classify drought severity. Briefly, the method is directed at a quantitative assessment of periods of prolonged meteorological anomalies by considering antecedent precipitation, the precipitation during a given period, and the duration and magnitude of the abnormal moisture deficiency. The difference 


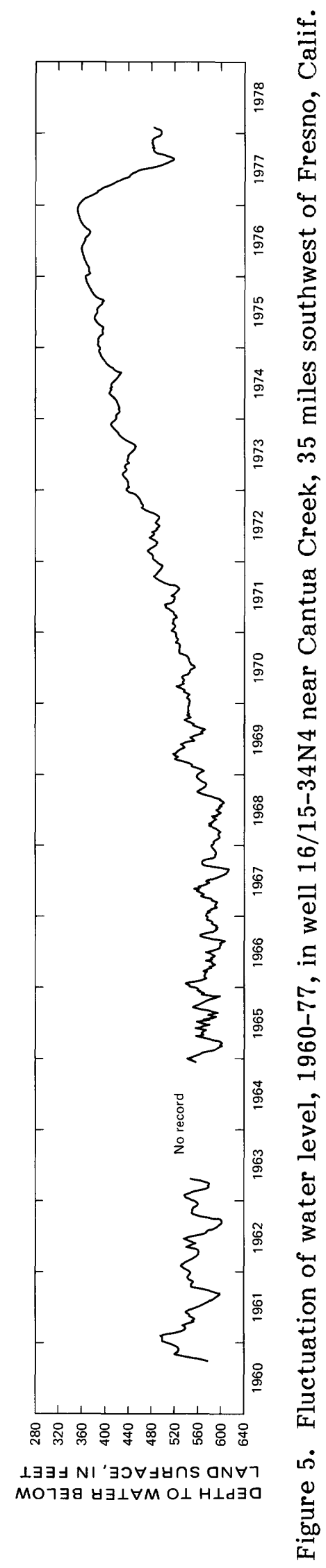

between the actual precipitation and that required to meet the demands of evapotranspiration is a fairly direct measure of the departure from normal.

Palmer (1965) computed indexes for many droughts prior to 1963 mainly in Kansas and Iowa. He concluded that a value of -4 corresponds reasonably well with "extreme" drought, and the minimum value that he tabulated is -6.2 for September 1956 in western Kansas. Therefore, the values of -7 to -9 determined for the drought in 1977 are rare extremes. In fact, early editions of maps showing Palmer indexes in this range described the conditions as "Too dry to measure!"

Figures 6 and 7 are a series of maps of the United States showing the isopleths of the Palmer index for selected dates in 1976 and 1977. As of May 1, 1976 (fig. 6a), the Palmer index indicated severe drought conditions only in California and western Virginia. By July 3, 1976 (fig. 6b), extreme drought conditions had developed in California and the eastern Dakotas-western Minnesota area. The severe drought in Virginia had eased, but eastern Maryland and Delaware were now affected as was northern New Mexico and much of Wisconsin. These same general areas shifted, changed shape, and enlarged by August 28, 1976 (fig. 6c). Early fall rains alleviated the drought conditions in all areas but the upper Midwest (fig. 6d). The lowest indexes computed in 1976 were -6 in California and -7 in South Dakota.

By February 1, 1977 (fig. 7a), the Palmer index had dropped to -5 in three areas of California, Oregon, and Washington and to -7 near the middle of Minnesota and Wisconsin. In the next 3 months (fig. 7b), the index had dropped to -7 or -9 in parts of the Pacific Coast States, southeastern Idaho and in the Minnesota-Wisconsin area. Also an area covering parts of Colorado, Utah, and Wyoming became dry enough to develop indexes between -4 and -6 . The July 2, 1977 map (fig. 7c) shows about the same indexes in the same general areas though the index dropped to -8 in central California. By October 29, 1977 (fig. 7d), the area west of the Great Lakes changed from severe drought conditions to normal or even moderately wet; whereas, the drought lingered in a large part of the 11 western states though the minimum drought index was now -6 . Shortly after the last map was prepared, rains came to most of 

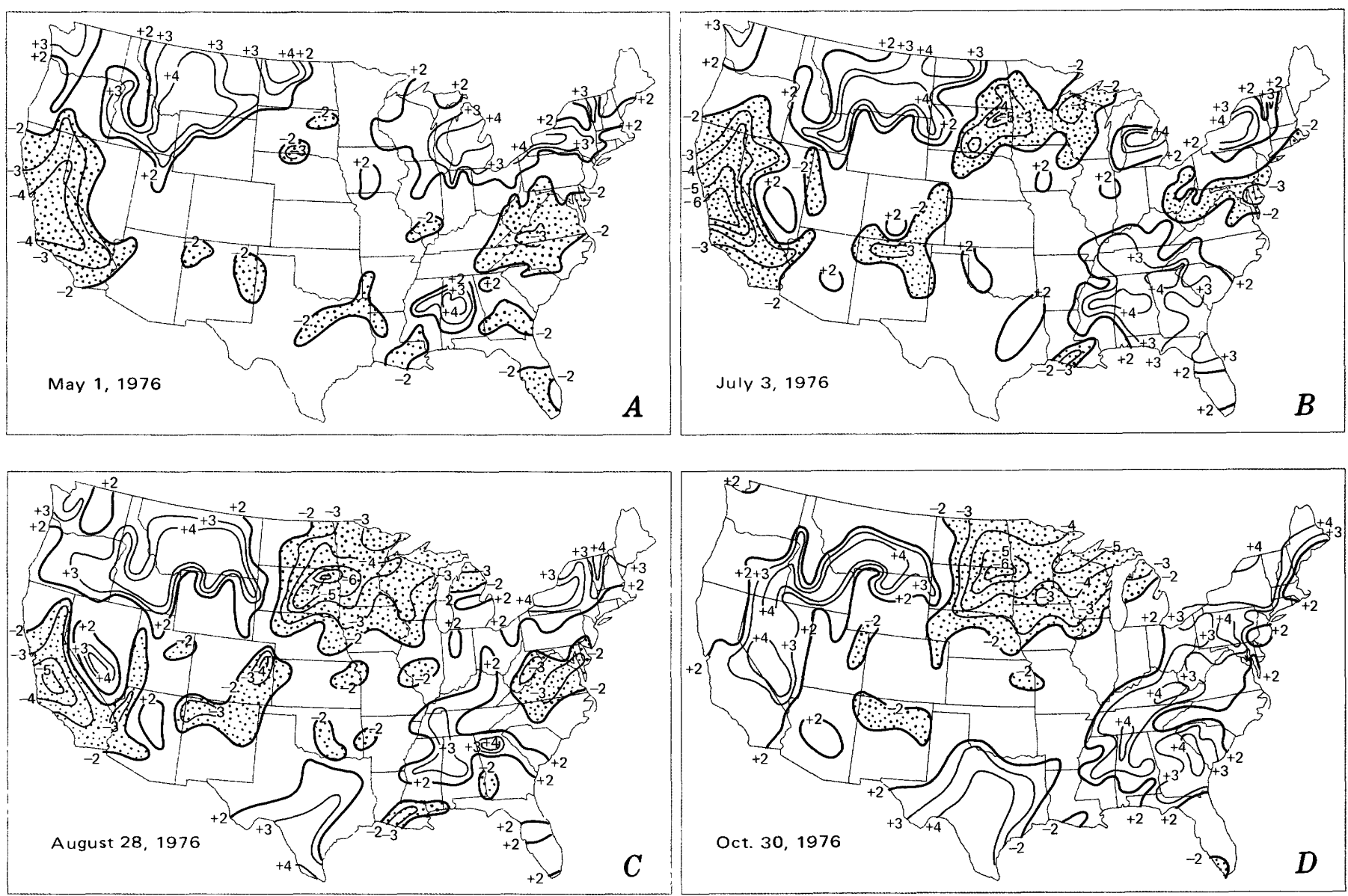

FXPLANATION

Above +4 Extreme +2 to +3 Moderate

-2 to -3 Moderate drought

Below -4 Extreme drought

-3 to -4 Severe drought

Values indicate departures from normal climate

Figure 6. Maps of the United States showing values of Palmer index on four selected dates in 1976 .

the drought areas and either ended or interrupted the drought.

Maps of the Palmer index for intermediate dates show continually changing patterns and values in response to rainfall, temperature changes, and other factors. A drought is a dynamic condition in time, space, and severity. It is the variations, sometimes only nuances, that change opinions about a drought and affect decisions on courses of action that might be taken to counteract drought.

Another ramification relates to a multiyear drought and its effect in a basin with storage facilities as opposed to one without. The former may have more serious problems than the latter because a larger part of the annual yield is used in a basin where water can be stored than in one where there is only natural flow.
The use of stored water during the first year or so of a drought is a normal operating procedure. Examples given later in this report show that releases of stored water in parts of the Western States in 1976 benefitted the consumer but led him to the conclusion that there was not a serious drought. Since 1977 was also very dry, stored water was depleted in some reservoirs and reached dangerously low amounts in others. Fortunately, 1978 was a wet year; otherwise, even more serious water-supply problems would have occurred.

The reasons for multiyear drought problems in basins that have been developed extensively for reservoir storage are manifold and complex. Some releases from storage are mandated by operating rules, see section on Legal Aspects; some are made to supply consumptive uses which generally are greater than in an 

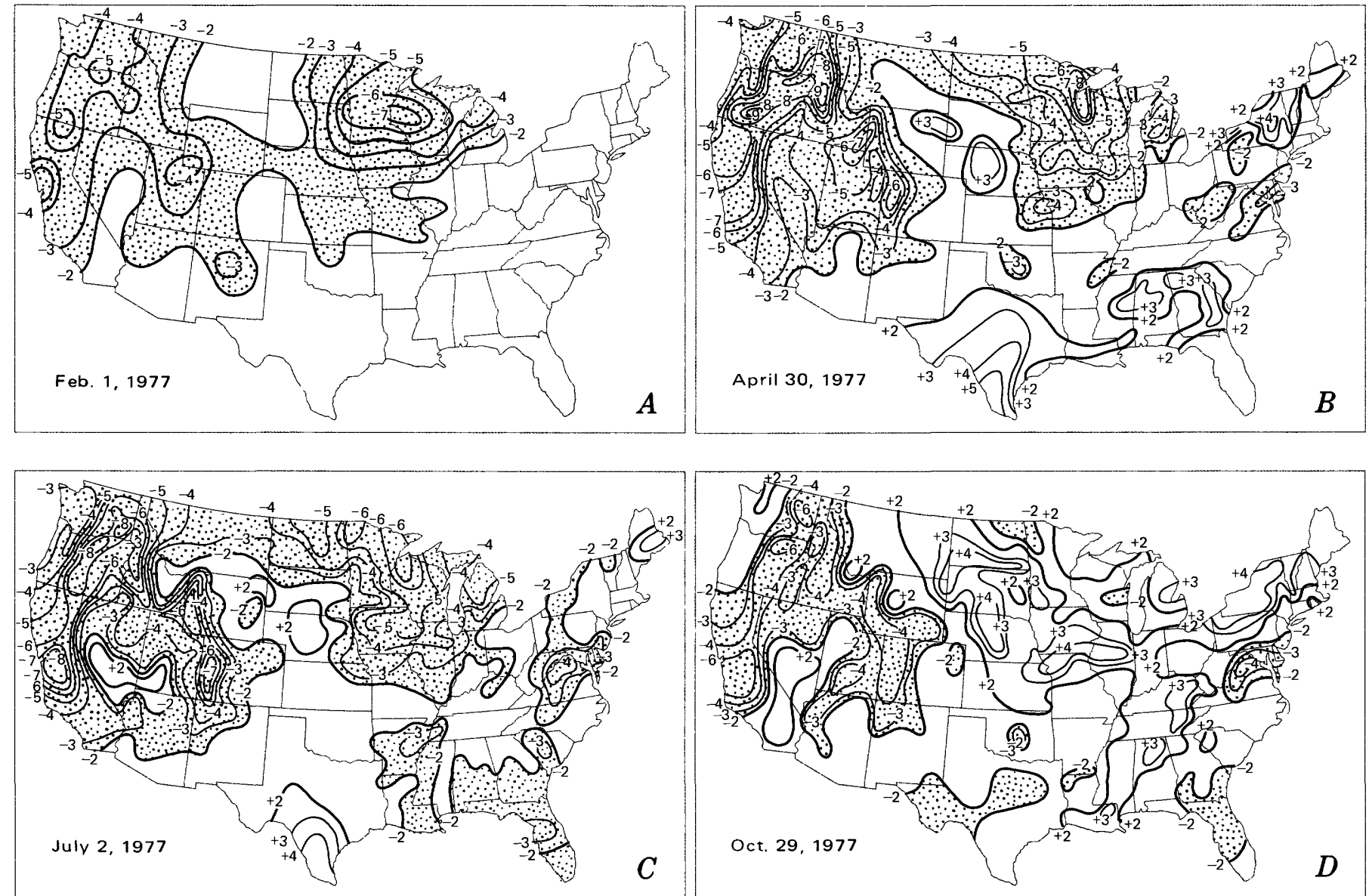

$\begin{array}{llll}\text { Above }+4 & \text { Extreme } & +2 \text { to }+3 \text { Moderate } \\ +3 \text { to }+4 & \text { Severe } & -2 \text { to }+2 \text { Near normal }\end{array}$

EXPLANATION

-2 to -3 Moderate drought

National Weather Service, NOAA

-3 to -4 Severe drought

Below -4 Extreme drought

Values indicate departures from normal climate

Figure 7. Maps of the United States showing values of Palmer index on four selected dates in 1977.

undeveloped basin; and others may be made to maintain diversions out of the basin. Also, evaporation losses are increased, and water development projects are not operated at maximum efficiency because of errors in forecasts of precipitation and runoff. And after the stored water has been reduced abnormally, the tendency is to store most of the runoff the next time it occurs to replenish the water released. This in turn may reduce downstream flows below the usual controlled amounts.

The above factors can be advantageous to some people and a disadvantage to others at the same time. The usual sequence is that the release of stored water enhances the water supply in the early stages of a drought. But when the carry-over storage is depleted during a multiyear drought, the increased demands for water that the development stimulated cannot be met, thus causing greater economic losses in the later stages of a prolonged drought.

The onset of a drought is usually a subtle process-certainly not as cataclysmic as other natural disasters such as floods and earthquakes. There is no first day of drought. People begin to suspect its approach and then suddenly find that it arrived some time ago. However, the effects of a drought can be more widespread, and can cause greater economic and social problems than the more dramatic events.

Throughout the 1976-77 drought, there were many people who were not convinced that drought conditions existed. Two examples: Some lived where localized storms produced enough rain at the right time that 
their crops were not seriously injured. Some, who used ground water for irrigation, had wells that were drawing water from aquifers that had not been affected yet by the drought; so their water supplies were not curtailed.

Troxell (1957) stated that economic factors often are what determine the existence of a drought. In other words, as long as water is available no matter what the source there is no drought. But when crops do not mature, livestock is undernourished, land values decrease, supplies run short, or unemployment increases, then people admit that a drought exists.

Many people lived in a drought area who were not directly affected by drought because water was not rationed nor were their usual activities changed; therefore, the drought was an abstraction to them. Because a drought produces effects in a scatter or random pattern, it is difficult to recognize its existence. Therefore, any definition other than one in very general terms is too restrictive.

Also, too many people react to a drought in the manner exemplified by the following flow chart.

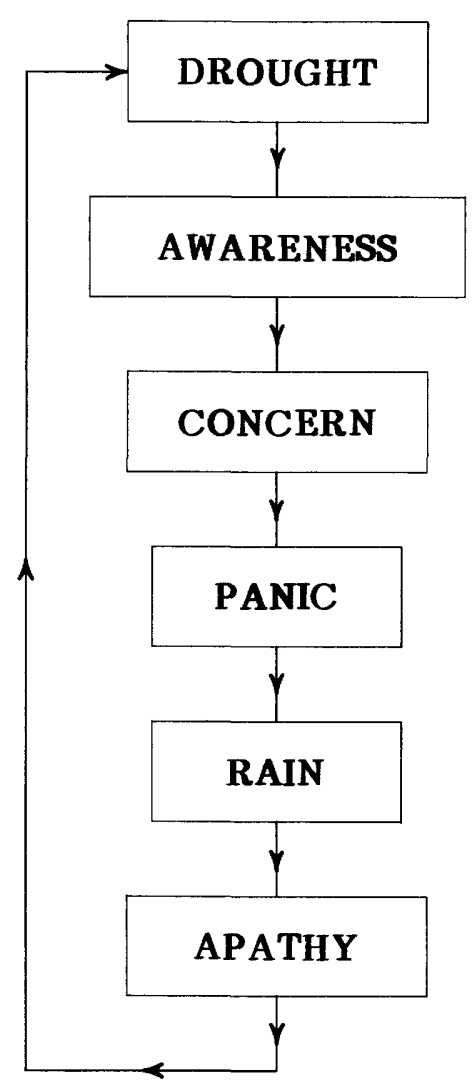

Adapted from O. H. Foehner (1977)
When this happens, planning for the future, approval of financing, and providing facilities to alleviate anomalous drought conditions in the future are impeded.

\section{IMPACTS ON PEOPLE}

"When droughts have occurred in the past, there have been few intelligent plans of action. Actions during a drought often can be characterized as too little and too late, if not actually counterproductive. While droughts cannot be forecast, their effects can be anticipated." The preceding statement was made in June 1978 by the Office of Science and Technology Policy in its report to the President's Committee for the Water Resources Policy Study. Some of the effects that can be anticipated and a few that could not are discussed in general terms in this section. Detailed information is presented in subsequent sections of this report.

\section{Public Water Supplies}

Water for domestic, commercial, and industrial uses in the United States under normal conditions was withdrawn at the rate of 168 gal/d (gallons per day) per individual served in 1975. About 175 million people are served by public-supply systems nationwide. In states affected by the drought in 1976-77 normal withdrawals ranged from $119 \mathrm{gal} / \mathrm{d}$ per individual served in Virginia to $331 \mathrm{gal} / \mathrm{d}$ per individual served in Utah (Murray and Reeves, 1977).

The $168 \mathrm{gal} / \mathrm{d}$ per individual served is an increase of 16 percent over the use in 1950, about the midpoint of the last drought in the southwest. And the number of individuals served has increased from 93.5 million to 175 million. Therefore, the demand for public water supplies has doubled in 25 years from 14 bgd (billion gallons per day) to 29 bgd. Increased stresses of this magnitude on the available water supplies and distribution systems could cause water shortages locally even during nondrought periods. Then when a severe drought does occur, the problems faced by the public are compounded.

Though the drought started during 1976 in California, the Upper Peninsula of Michigan, and Colorado, public water supplies were not seriously affected until later. Supplemental supplies from wells and the use of carryover 
storage were the main sources of water used to meet the public's demands.

It was not until the winter of 1976-77 that many public entities realized that a serious drought was imminent. Water managers appealed to the public to conserve water and to voluntarily reduce water use by 10 percent. Suggestions were offered on how to save water, some utilities furnished flow restrictors for showers and faucets, and the news media cooperated by publishing or televising pictures of reservoirs with very little water and by keeping the public informed.

A small percentage of the public seems to be very skeptical of any warnings about hydrologic phenomena that are usually considered natural, whether they are floods or droughts. Some people reacted by claiming that there was no serious drought and that one group or another was putting out propaganda to further its own motives. As the drought worsened, most skeptics became believers.

Sometime during the period February-April 1977, mandatory water rationing was imposed in many areas, and additional water districts established reduced quotas during the summer. An allowance of 75 percent of the amount used during the same billing period in 1976 was fairly common, and other rations ranged from 30 to 90 percent. Users were warned once or twice if they exceeded their allowance. The next time they were penalized or fined for any overuse; and in a few homes, flow restrictors were installed so that it took 20 minutes to draw water for a bath.

Typically, a few people made light of the drought. There were jokes about when or where one should use or not use water and stories of unique situations that no one could foresee. Someone suggested that you should shower with a friend to conserve water! A suburbanite drove to his club in San Francisco to shower before going to work, thus shifting his water use from his allotment to someone else's. And one citizen claimed the drought in California was caused by the rain in California which is only half as wet as rain should be!

In spite of the carefree attitude and the people who would rather pay fines than curtail their water use, water use was reduced significantly and commonly below the ration allowed.

Several public-supply systems found it necessary to raise rates because their operating costs remained about the same but revenues were less. The city of Bessemer, in the western end of the Upper Peninsula of Michigan, had to import water by truck starting in December 1976, after their wells went dry.

The Marin Municipal Water District, just north of San Francisco, Calif., imposed one of the strictest water rationing programs upon their customers when they set a limit of just 50 gal per day per person. To ease the water shortage, they constructed a 24-inch pipeline across the Richmond-San Rafael Bridge and obtained water from the State Water Project through the facilities of the East Bay Municipal Utility District. In the interim, entrepreneurs trucked water from San Francisco and other nearby areas to large estates to save the valuable landscaping and to dairies. This was a thriving business while it lasted.

\section{Rural Water Supplies}

Rural use of water other than for irrigation is primarily for domestic and livestock use. In 1975, 42 million people depended upon their own supply; and they withdrew 5 bgd (Murray and Reeves, 1977), an increase of 37 percent since 1950 . About 95 percent of the rural domestic water and 58 percent of the water for livestock comes from wells.

During the drought, shallow wells went dry or yielded meager quantities of water because the additional pumping from deeper wells lowered the water table more than in the past. Solutions to water problems at many individual homes and farms were not easy, and many were expensive. Numerous wells located in alluvium were deepened when one of the very busy well drillers could schedule the work and a loan could be obtained. In the Upper Peninsula of Michigan, drilling wells deeper did not always produce enough more water to alleviate the drought because in most of the area the deeper formations are not good aquifers.

More than 1,000 wells in the Upper Peninsula went dry, and the Michigan National Guard and State Police trucked water to some areas. In several northern Michigan counties, people had to obtain water for cooking and drinking from schools or community buildings that had wells with more dependable water supplies. Water for sanitary purposes was taken from streams and lakes. 
The number of livestock on many farms in several States was reduced to conserve water, and water was hauled to supply those retained. Some animals were moved to places with sufficient water, and ranchers received financial assistance from the Federal Disaster Assistance Administration or the Department of Agriculture for the move.

\section{Water for Irrigation}

Irrigation-water withdrawals amount to roughly twice the water withdrawn for public, rural, and industrial uses combined, excluding water used by electric utilities in power generation. Ground water supplies 40 percent of the irrigation withdrawals nationwide; but in eight western States in the drought areas, ground-water withdrawals normally average 32 percent.

The first effect of a drought on agriculture is low soil moisture caused by the below normal rainfall. The additional irrigation required depletes the reserves in both surfaceand ground-water reservoirs. Where surface supplies were practically exhausted, additional wells were drilled or existing wells were deepened. The increased use of ground water, though expensive, was enough to produce nearnormal crop yields in many areas.

Irrigation generally is considered a lower beneficial use than municipal use; so in some places irrigation diversions were reduced to provide water for municipalities. Conversely, the California Aqueduct was shut down south of the Tehachapi Mountains south of Bakersfield because additional water was available to southern California from the Colorado River. The additional water remaining in the San Joaquin Valley was used mainly for agriculture.

In Idaho and Washington, some temporary redistributions of irrigation water were made. To save orchards and vineyards, they were irrigated rather than field crops. Also, irrigated acreage was reduced or crops needing less water were planted in anticipation of decreased water supplies.

Very low soil moisture because of the longer than normal periods between rains during the growing season in the Midwest stunted corn (fig. 8) and other farm products.

\section{Water for Hydroelectric Power}

Hydroelectric power is generated in 46 of the 50 states; therefore a widespread drought will affect seriously the ability of utilities to generate hydroelectric power. When storage in a reservoir is drawn down, the head on the generator is reduced and less power is produced. The water level was lowered below the intakes to a few powerhouses in California, and power generation ceased. At other sites, the number of hours that power was generated had to be reduced.

The reduced hydroelectric generation required increased use of natural gas and oil at steam generating plants which added millions of dollars to the cost of producing electrical energy. The additional cost was passed on to the consumers when rates were raised.

"Rolling brown outs" were expected in California, and electric-utility customers were advised of the proposed schedules. "Rolling brown outs" are planned periods of a few hours when electric service to different areas or to different classes of customers would be interrupted on a scheduled rotation to reduce the demand for electricity and therefore reduce the water use by hydroelectric plants. However, no "brown outs" occurred. Reduced hydropower output in the Columbia River basin affected some of the large consumers such as aluminum plants. Cutbacks in industry that is dependent on electric power increased the number of unemployed.

\section{Water for Forests}

Drought conditions were severe in many of the nation's forests; therefore, the fire season started earlier than usual-as early as April in Idaho. The larger fires in 1976 in California occurred in June and July burning 85 percent of the 165,000 acres burned in 1976. Normally only 25 percent of the acreage burned annually is burned by July 15 .

The obvious results of fires can be seen immediately, but the secondary results of fires will not be known for awhile. When rains finally come, erosion of hillsides, head and bank cutting along streams, deposition of sediment and debris, and flooding will occur in various degrees along streams draining the burnedover areas. 


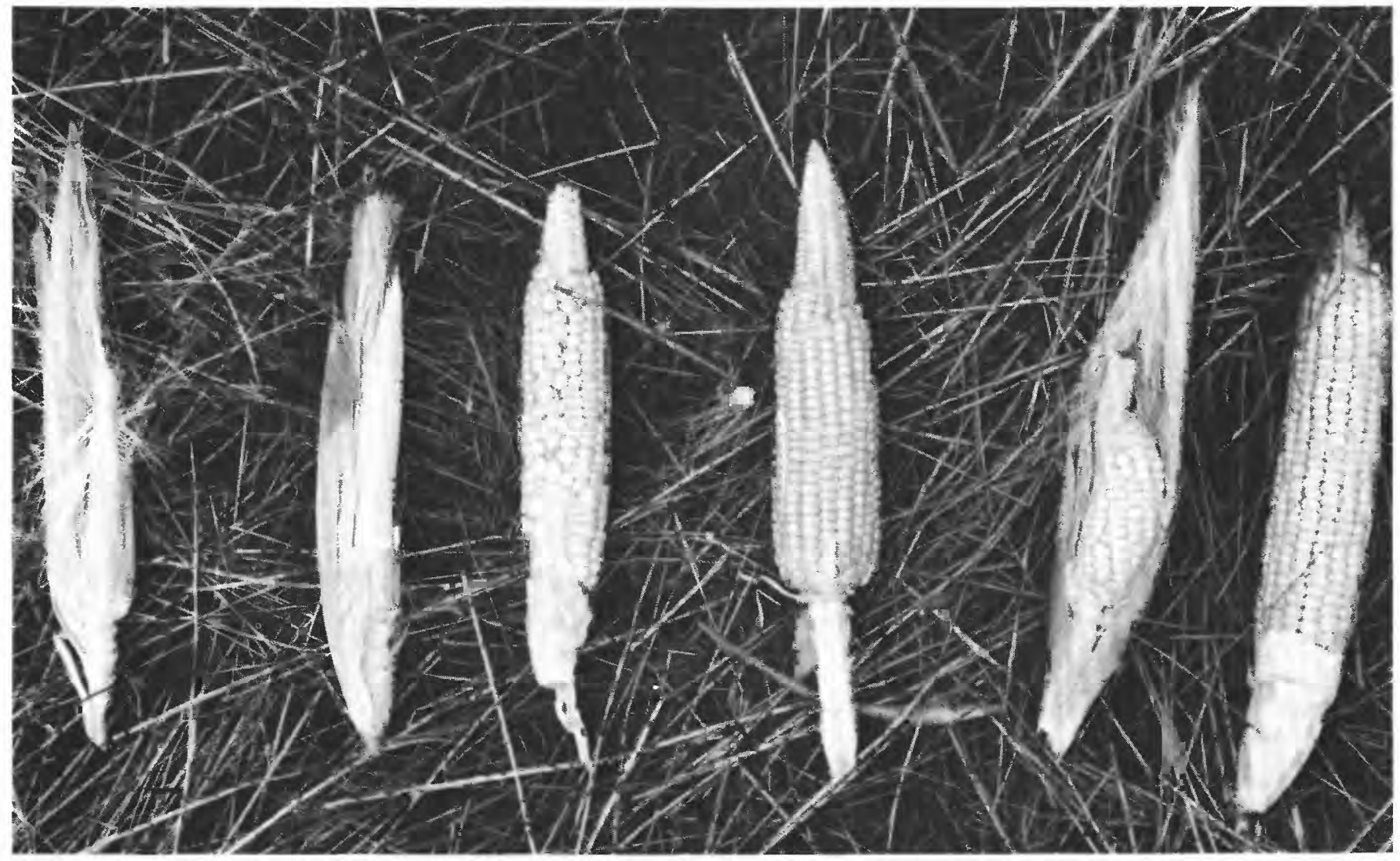

Figure 8. Stunted ears of corn caused by drought in Midwest. Photo by R. J. Modersohn, Des Moines Sunday Register.

Recent research by the U.S. Forest Service has shown that another effect of forest fires, at least in chaparral, is the formation of nonwettable or water repellent soils. When chaparral plants and the litter on the ground are burned, a complex of waxlike substances is produced which tends to coat the soil particles and makes them hard to wet. The fire vaporizes these substances, and the gases that are heavier than air sink into the soil layer where they cool enough to recondense and again coat the soil particles. This second process makes soils that formerly were only hard to wet virtually waterproof. If the water cannot enter the soil, it must run off; therefore, the flood potential is increased (Wells, 1978).

Another long term effect of the drought is the damage to timber and other trees from insects, disease, and smog. Vegetation undergoes additional stress when it does not receive some minimum amount of moisture or does not receive it at the proper time to foster growth.
Therefore, vegetation is more susceptible to deleterious influences because of a drought.

\section{Water Quality}

Whenever streamflow falls below threshold amounts, water-quality problems can be expected soon thereafter. The inability of low streamflows to flush and dilute contaminants in stream channels may let concentrations from waste discharges increase to the point that the water is not usable. Higher than usual concentrations of dissolved solids, one of the indexes of water quality, occurred in North and South Dakota, western Colorado, and Ohio. Both natural sources and pollutants contributed to the high concentrations.

The lower the flow for a prolonged period, the less water there is to absorb wastes that demand oxygen. A decrease in dissolvedoxygen concentrations, called an oxygen sag, can cause unpleasant odors and fish kills and will reduce the ability of a stream to purify 
itself naturally. Oxygen sags were reported in Minnesota and California.

Higher water temperatures are associated with low streamflows and shallow depths. Aquatic growths may increase; fish, particularly trout, may die; evaporation from water surfaces will increase, and the efficiency of water-cooled systems is impaired when water temperatures increase.

\section{Water for Fisheries}

Fishery resources are important economic factors in many regions of the United States, and low streamflows resulting from drought conditions can cause serious problems to the fish populations. A few problems are mentioned briefly below.

The combination of low streamflow and very low temperatures in the eastern part of the country increased the ice cover on streams and farm ponds and resulted in fish kills. A similar result occurred when high temperatures in several streams in Idaho and in the Trinity River in California occurred in 1977. Hydroelectric power generation was suspended at Trinity Dam so that cooler water could be released from lower levels of Clair Engle Lake to preserve the fishery. The level of Lake Tahoe, Calif., dropped below the outlet channel and part of the Truckee River dried up. There was a reduction in the fish population locally, but no fish kill because the fish moved downstream and adjusted to the reduced flow there (California Department of Fish and Game, oral commun., 1978).

To protect several races of salmon and steelhead trout from near extinction, special flow releases and spills were made in 1977 at dams in the Columbia River basin to augment the low flows and move the juvenile salmonids more rapidly to the ocean. See page 59 . Operations at four reservoirs in northern California were altered to provide the best water temperatures possible and to stabilize the flows during the salmon spawning seasons.

There are no facilities on many Pacific Coast streams to enhance flow conditions for fish; therefore, the number of fish that could successfully spawn was reduced. This condition will affect the fisheries for at least several years (California Department of Water Resources, 1977c).

\section{Water for Recreation}

Water-based recreation is a major activity considering the number of people involved and the economic value to many areas. Skiing, boating, fishing, swimming, and water skiing are pursuits that use water directly, and camps or homes around lakes or along streams are enhanced by the aesthetic values of water.

Skiers and ski resort operators were among the first to feel the effects of the drought. Low snow depths and a short season made most skiing only fair at best. Also, warmer than usual weather in the Sierras hampered the production of snow by machines, and resorts with equipment to move snow onto the ski slopes and to pack it did so even though this procedure was costly. The lack of patronage and the short season were enough to cause several resorts to declare bankruptcy.

Boaters and marina operators had drought related problems during the summer and fall of 1977 when water levels in reservoirs were drawn down to such an extent that marinas were stranded long distances from the water. Temporary expedients were needed to provide launching facilities. Obstacles to boating were exposed in some lakes, and white-water boaters in kayaks or rafts found more rocks showing than usual because of the low streamflows. Scheduled float trips were canceled; and trips by individual parties were about half the number in 1975.

A number of recreational areas in parks and forests were closed to vacationers because of lack of water or because the fire hazard was too great. The ban in northern Minnesota came just prior to the hunting season, and resort owners were faced with a large number of canceled reservations.

\section{Water for Navigation}

Major navigation problems did not develop because of drought-induced low flows. Adequate flows were maintained on the Missouri River by releasing water from the main stem reservoirs. Low flows in 1976 on the upper Mississippi River were the reason that pleasure boat operators were requested to reduce their use of locks because the long time necessary to fill the locks delayed other traffic. Shoaling and dredging on the lower Mississippi River were very much like numerous other years 
(Corps of Engineers, oral commun., 1978). However, the combination of lower than usual flows in the Mississippi River between St. Louis, Mo., and Cairo, Ill. and the severe ice conditions halted navigation for several weeks in January and February 1977.

Two ferries that cross the Missouri River north of Lewistown, Mont., were taken out of service in June 1977 because of low flow in the river. Usually, any cessation of ferry service does not occur until late fall. Minor navigation difficulties occurred on the Sacramento River in California.

\section{ADAPTATION TO DROUGHT}

The adaptation to drought falls into two main categories, short-term planning and longterm planning, plus a parallel category, legal aspects, which relates to the first two. These are presented mainly in general terms with statements related to the 1976-77 drought to illustrate the general conditions.

\section{Short-term Planning}

The information base related to drought, both past and present, was an important factor in the adaptation to the drought by public and private entities and by individuals. Numerous Federal, State, and local agencies, and public utilities provided information on the weather, snowpacks, streamflow, reservoir storage, ground-water levels, water quality, and water use. The field data collected had to be analyzed and forecasts or predictions made; otherwise the water managers and government officials would have no realistic basis for decisions on more efficient ways to allocate the limited water resources.

\section{Changes in Water Use}

The mandatory rationing of water in several areas was viewed with dismay and apprehension. But residential use in one service area near San Francisco was reduced by 45 percent between April 1 and December 31, 1977 rather than just the mandatory reduction of 25 percent. A contributing factor was the surcharge added to the water bills.

The reader is cautioned to be aware of the bases for which percentages are given. In the preceding paragraph, 45 percent is an impres- sive figure, but domestic use in northern California is only about 6 percent of the total water use. Therefore, a 45 percent reduction is less than 3 percent of the total though it is an essential contribution to water conservation in time of drought. At the opposite end of the scale, flows in some streams in the Pacific Northwest dropped down to the 40 percent of normal range; but 40 percent of a relatively large flow was still enough water to supply domestic needs without rationing, though water for other uses had to be carefully managed.

Several water-supply systems were adversely affected when their source of water was depleted or their storage was inadequate to equalize the supply. A number of utilities upgraded their systems when they developed ground-water sources to supplement surfacewater supplies, installed storage tanks, or took other steps to meet current problems. Revamping distribution systems was usually either not feasible or took too long to meet the drought emergency.

Where possible, an outright purchase was made of water from another user or another area to supplement dwindling supplies. A few municipalities were able to use the priority rights of agricultural ditch companies for their supply in exchange for effluent from the municipal sanitary system.

Good quality water was pumped from mines in Colorado for municipal use. However, where the water was allowed to flow over mine tailings once it reached the surface, the quality deteriorated.

In many parts of the United States, more ground water was pumped than usual to supplement depleted surface-water supplies. But in Arizona where ground water is the major source of supply and the annual overdraft averages 2.2 million acre-ft or nearly half of the 5 million acre- $\mathrm{ft}$ pumped each year, the overdraft in 1977 was about the same order of magnitude. Ground-water levels dropped a maximum of 13 to $20 \mathrm{ft}$.

\section{Changes in Irrigation Practices}

The shortage of surface-water supplies or rainfall on nonirrigated land caused many problems for the farmers and ranchers and for the governmental units responsible for allocating water. The latter groups distributed the 
available supplies as equitably as possible, consistent with the legal doctrine in effect.

In some places, local water users arranged exchanges among themselves. In Colorado, downstream water users temporarily relinquished their rights to released flows in streams and in turn received water from nearby irrigation ditches. The very high transit losses in alluvial streams would have depleted the released flows excessively; thus reducing the supply at the time it is needed.

Normally irrigation is not needed in Georgia; but if the farmers could find irrigation pipe and other accessories, they irrigated for the first time since the 1950 's. Soybean, peanut, and other crops were not planted as early as usual because moisture is needed to activate the chemicals in pesticides and weed control agents.

Innovative farmers in California produced nearly the normal value of crops on about 80 percent of the usual water supplies (H. W. Greydanus, oral commun.; 1977).

\section{The Role of Forecasting}

Weather - Forecasts of weather for water supply are more complex than the day to day forecasts of rain or sunshine. The reliability of weather forecasts beyond a week or so decreases rapidly, though some forecasters will challenge this statement. The National Weather Service publishes 30-day forecasts in general terms; that is, the broad areas of the United States where temperatures or precipitation will be above or below normal. Forecasts are made twice a month. Some meteorologists in private practice make longer range forecasts for their clients.

A man in Wisconsin maintains that a global cooling is occurring that could extend the typical 5-year drought cycle of the past to a 10 -year one. Others contend that there is no evidence of any "cycle" in the weather; whereas, others have postulated cycles of various lengths based on sun spots, tree rings, and other evidence.

In this decision-making process, the water user considers the weather forecasts along with other factors affecting his particular endeavor such as economic, personnel, environmental, or social constraints.

One problem with weather forecasts is the wide range of predictions both by the profes- sionals and by self-styled experts. Forecasts for the 1977-78 winter for the West Coast States ranged from well below normal to well above normal. It is the writer's opinion that many decisions made by water managers were based more on the chance that the drought would continue beyond 1977 rather than on the determination that a given weather forecast was reliable or unreliable.

Weather forecasts are also an integral part of weather modification activities. To seed or not to seed is the question. The right kind of clouds over the target area are essential; but during a drought, the frequency of occurrence at the right place is markedly reduced. Therefore, weather modification during a drought is apt to produce the least amount of water when it is needed the most.

Runoff-Several Federal and State agencies have developed techniques to forecast snowmelt runoff for specific seasons such as the period April 1 to July 31, or October 1 to September 30 which is the water year, or the calendar year. The techniques make use of runoff, precipitation, water content and extent of the snow pack, and soil moisture conditions up to the date of the forecasts. Several forecasts are made usually for selected amounts of precipitation during the remainder of the forecast period and a range of temperatures that might be expected.

Recently digital models have been developed to estimate snowmelt runoff. A major advantage of such models is that they do not require the field data related to the snowpack that are expensive and sometimes hazardous to collect. Also, forecasts can be made whenever a set of precipitation data is obtained rather than once a month. The models are calibrated using low-elevation precipitation and runoff data from previous years. Public utilities, irrigators, and other water users rely heavily on runoff forecasts to plan their management of the water resource. An unreliable forecast, whether too high or too low, can mean the loss of considerable income by everyone involved with water.

No matter which technique or model is used, drought conditions usually make it necessary to extrapolate beyond the calibration data. Therefore, the reliability of the forecasts is reduced. Even so, most of the runoff forecasts made in 1977 turned out to be good estimates of the runoff that did occur. One 
notable exception was the extremely low runoff forecast that was made early in March 1977 for the Yakima River in Washington. The early forecast was revised upward in mid-May to predict runoff of 50 percent or more. The larger than anticipated and previously unquantified return flow from irrigation was the main reason for the big change in the forecast. In the meantime, some farmers did not plant crops or reduced the acreage planted, and some made sizeable investments in wells which may not have been needed.

Ground-water use -A recent development that was made possible by large electronic computers is the digital modelling of groundwater basins. The output from the model is a forecast but in a different sense than forecasts of weather and runoff. Once the model is calibrated, it can be operated to show what will happen to the ground-water resource in the area modeled if different water management plans are implemented. Some models will indicate what will happen to water levels, to the volume of water, and to the water quality in one or more aquifers. The digital model can be a powerful tool to improve the operational efficiency of aquifer systems particularly during a drought period when unusual stresses are applied to aquifers by increased pumping from existing wells and from proposed wells.

Base flow projections - The natural recession of streamflow after a storm follows a regular pattern. Previous records at gaging stations on streams are used to define recession characteristics. Then when a drought occurs, streamflow data obtained early in the season are the bases for a projection of the recession relations from which stream discharges and stages can be estimated for various dates later in the season. This was done for nearly 100 sites in Idaho so that anyone diverting water from a stream could determine if enough water would be available and if the intake would be low enough to divert the flow.

\section{Long-term Planning}

Public and private agencies have always made long-term plans for water developments because the location of a source of water, the feasibility and design studies, the financing, and the construction take many years to accomplish. Now that a drought has occurred, new data are available that might affect the operation of existing water-supply systems and the design of proposed developments. Analyses of the new data and implementation of the results of the analyses will take awhile.

Now that longer records of streamflow provide a good data base and new statistical techniques and computer capabilities have been developed, more long range plans are based in part on probabilities of occurrence and the risk involved. One example was given earlier in this report (see p. 6 and fig. 2). It is a frequency analysis of low flows which indicates how the flows in 1977 relate to the flows over the long-term record and documents that such low flows are truly rare events. Whether or not a new development would be designed to prevent such low flows in the future depends upon many other factors also, but extreme events are frequently used as the bases for designs.

The large reductions in the amounts of water stored in reservoirs have been described previously. If the drought had continued in 1978 , water supplies in many areas would have been reduced drastically, because only small amounts of stored water would have been available. The low reserves for carryover to 1978 led one agency representative to state that they would never let the carryover storage get that low again. To prevent this will take a reassessment and a change of operating rules and in some cases legal actions will be necessary. The latter at least will be a longterm effort.

Research is continuing to develop better techniques and models to forecast water supply conditions not only more accurately but more frequently so that more efficient management and use of water can be accomplished. Development of better sensors to measure factors upon which forecasts are made and better means of transmitting the data to central locations are being pursued. The use of satellites and meteor bursts to transmit signals is becoming common.

Water rights, water law, the general lack of law relating to certain aspects of the water resource, particularly ground water, and economic, social, and bureaucratic factors are intrically interwoven. Solutions to water related problems, both with respect to 
droughts and floods, will take time and will require statesmanship by all concerned.

\section{Legal Aspects}

Many proposed actions to alleviate the drought ran into legal or quasi-legal roadblocks. New laws, legal and administrative decisions, or temporary agreements between the parties or entities involved had to be made within short time frames to allow some of the proposals to be implemented. Other proposed actions could not be accomplished, but they are the bases for study and possible new legislation, agreements, or decisions in the near future. A few brief descriptions of the legal aspects of drought related problems follow.

Water users made suggestions to operating agencies about what the agencies should do or should not have done. In one case, the U.S. Bureau of Reclamation was criticized for releasing too much water from Shasta Lake, Calif., in 1976. The inter-agency agreement for operations at Shasta Dam requires the inflow for the year to drop below 3.2 million acre-ft before steps can be taken to curtail water deliveries. But inflow was 3.7 million acre-ft; therefore, water was released to generate electricity, to supply some water for irrigation, to meet public health standards, and to help control salinity in the Delta.

In the San Joaquin Valley, Calif., a rancher proposed to pump water into the DeltaMendota Canal and take delivery of his water farther down the canal. This was physically possible, but the proposal was turned down because the mixed water might not meet waterquality standards at the outlet of the canal.

In Iowa, two counties challenged the right of the Iowa Natural Resources Council to issue permits for irrigation wells to farmers. Temporary injunctions were obtained to halt the practice on the grounds that public water for private profit is subject to provisions of the Federal Environmental Protection Act; therefore, an environmental impact statement is required for each permit. The counties also contended that the Council ignored the potential for pollution from irrigation of fields that have been treated with chemical fertilizers and weed and insect killers. The problem was intensified because the drought had increased the normal 45 applications per year for permits to more than 500 in 1976 for all of Iowa.

Though technically not a legal action, the Corps of Engineers could not unilaterally reduce releases from two reservoirs in Iowa below minimum releases agreed upon by the Corps and the water users until all parties agreed to new minimum releases at two-thirds of the existing discharge for the duration of the drought. See page 30 .

The flow of the North Platte River near Casper, Wyo., was the third lowest on record in July 1977 and dropped almost to the flow that would have called for a reduction of the amount diverted to the city of Casper unless some arrangement could be made with several oil companies and many agricultural users that have water rights senior to the right held by the city of Casper. There is no wyoming law that stipulated that humans have a first right to water. Only the natural flow of the North Platte River is available for domestic use, and that released from storage developed for agriculture and other uses is not.

In the Shoshone River basin in northwestern Wyoming, water deliveries to an irrigation district were shut off for 2 days in May 1977 due to drought conditions because higher priority (earlier than 1905) rights had to be protected.

State water law in Nebraska does not limit the amount of ground water that can be pumped, but the reasonable use doctrine specifies that it is to be used on the overlying lands. This imposes a constraint on the conjunctive use of surface water and ground water because ground water cannot be pumped into a canal for distribution on "non-overlying" lands.

Nebraska law and law in many other States do not recognize the interconnection between surface-water and ground-water sources; therefore, the increased pumping-drought or no drought-has depleted the streamflow in several areas. This has jeopardized the senior water rights, some dating back to 1890 , of irrigators using surface supplies and their ability to repay their share of the Federal investments for irrigation projects.

One example is the Frenchman CreekEnders Reservoir area about $50 \mathrm{mi}$ west of McCook, Nebr. See figure 14. Almost the entire flow of Frenchman Creek is groundwater discharge, and the average annual flow at the Imperial gage just upstream from 
Enders Reservoir was 52,840 acre-ft for the period 1941-67. By 1967 there were only 450 wells in the two counties upstream from Enders Reservoir, but by 1976 there were 1,640. The major causes for the increased number of wells and increased ground-water withdrawals were below normal rainfall in 1968-70 and the greater number of centerpivot sprinkler systems. The connection between ground-water withdrawals and streamflow has been substantiated by single and double mass curve analyses of monthly flows (Lappala, 1978). Ground-water levels have been dropping at a rate closely corresponding to the increase in the number of wells, and the flow at the Imperial gage has decreased to 29,920 and 25,310 acre-ft in 1976 and 1977 respectively. The latter flow is only 48 percent of the 1941-67 average and provided only half the water that was used for irrigation during the 1960 's. Without legislation to control ground-water use, those using surface supplies are on a collision course with those using ground water. Lengthy and costly suits may be imminent.

To use weather modification or not to use weather modification is a knotty problem legally as well as technically. Nebraska's statutes assert a "sovereign right" to the moisture in the atmosphere over the State. Therefore, any unilateral decision to use weather modification in nearby States is of concern to Nebraskans. They desire to cooperate in the decision process so that optimum benefits may accrue to Nebraska. However, cloud seeding operations that have been conducted in several areas of Colorado in previous years were expanded to other areas in 1977. But fewer storms and the paucity of the right conditions for seeding made results inconclusive.

The State of Washington started a weather modification project on February 28, 1977, and several public utilities continued their programs. The State of Idaho threatened to sue the State of Washington if Washington seeded clouds that might carry moisture to Idaho. By late April 1977, the results of the weather modification activities could not be determined though some success was claimed for increasing the snowpack in the Cascades.

The increased use of weather modification has resulted in laws in some States that require the contractor to have a license and to meet specified standards. Other States are considering what steps they believe are necessary.

Congress passed The Emergency Drought Act of 1977 which allowed the Bureau of Reclamation to defer annual operation, maintenance, and construction costs up to 5 years in lieu of other expenses incurred by irrigation districts.

The large number of requests for permits for new wells or additional irrigation water from surface sources created problems with the existing processing procedures. Legislation was enacted, in Iowa, for example, to streamline the processing so that the Government would be more responsive to the needs of the public. In a drought emergency, time is an important factor.

The increased use of ground water in Minnesota caused interference problems between wells. Legislation was passed in 1977 that requires anyone requesting a permit for a well to provide detailed hydrologic information before a permit will be issued. The required information is not available for all proposed well sites.

\section{CHRONOLOGY OF THE 1976-77 DROUGHT}

The drought that occurred in many parts of the United States during 1976 and 1977 generally was not recognized as being so serious until well into 1977. Americans seemed optimistic that ample precipitation would fall; and if not, they had confidence that the dams, canals, and distribution systems they had paid for during the last 70 years would tide them over any "dry spell."

Americans did survive, but not without some stresses, strains, and economic losses. Even so, there were individuals and companies that profited from the drought because they were in the right place with the right products or services needed to ameliorate the effects of the drought.

A number of areas had below normal precipitation prior to 1976 . The western part of Iowa, eastern South Dakota, and most of Nebraska had some drought effects as early as 1974 , and precipitation during 1975 was below average in many areas of the country (Environmental Data Service, 1976). Except in the areas with nonirrigated agriculture, people generally did not consider the below normal precipitation to be a serious problem because 
water demands were met generally by water withdrawn from storage in surface-and groundwater reservoirs.

The amount of snow in the western mountains is a very important factor with respect to uses of water for agriculture and hydroelectric power. The snowpack acts as a natural reservoir storing moisture in the winter and releasing it in the spring and summer. The snow melt runoff provides water for both nearby areas and areas such as those along the Missouri and Platte Rivers, that are long distances from the mountains. Also, the seasonal distribution of precipitation in the Pacific Coast States, where about $85 \%$ of the precipitation falls between November and March and very little from June through September, makes the snowmelt contribution to the water supply of the moisture deficient areas a valuable resource both in quantity and in timing.

Therefore, the deficient precipitation over large parts of the nation and the poor snowpacks in the Cascades, the Rocky Mountains, the Sierra Nevada, and other mountains in the Western States were the most important causes and the earliest indications of the drought in 1976 and 1977.

An extended freeze is not generally a factor in a drought, but the drought conditions were intensified over a large area of the Midwest and East during the extremely cold winter of 1976-77. Water supplies that were dwindling were reduced even more when water was taken out of circulation as it was being stored temporarily as ice. In addition, the distribution of water was hampered by the freezing and bursting of water lines. The severe winter conditions increased the concentration of dissolved solids in streams and decreased the dissolved-oxygen concentrations.

The following subsections contain drought information for 10 of the WRC regions by region and brief statements about conditions in the other 11 regions. For the reader's benefit, a summary of the main features of the drought in each of the 10 regions is presented ahead of the rest of the information.

\section{Great Lakes-WRC Region 04}

The Great Lakes Region (fig. 9) includes all of Michigan, and the fringe areas of Minne- sota, Wisconsin, Illinois, Indiana, Ohio, Pennsylvania, and New York that drain into the Great Lakes.

The most recent dry spell prior to $1976-77$ in Wiscosin was in 1963 when spring runoff did not fill the reservoirs before the dry summer began. Runoff was low in parts of the region during the $1924,1925,1931,1934,1940,1941$, $1955,1958,1963$, and 1964 water years. The most widespread drought was that in 1931 .

Hindsight has verified the fact that the recent drought started in the northwest part of the region in May 1976 and progressed to the south and east. By August 1976, almost the entire region had deficient precipitation, but the most serious effects were in Michigan, Minnesota, and Wisconsin. The Palmer index dropped to -4 at many locations and to -9 in northern Wisconsin and northeastern Minnesota for extended periods. High summer temperatures and an extremely cold winter augmented the drought. Rain in the late summer and fall of 1977 eliminated the severe drought conditions.

Monthly runoff reached new record lows for the month generally in the fall of 1976 or the winter of 1976-77. Low-flows had probabilities less than 0.02 at several sites. New minimum water levels occurred in many wells, and a large number of wells went dry. No major water-quality problems were reported.

\section{Precipitation and Runoff}

Precipitation during 1975 was generally above average throughout the Great Lakes Region, and this trend continued through March 1976. Significant negative departures from normal began to show up in Minnesota in April 1976 such as at Duluth where the April precipitation was only 29 percent of normal. Deficient precipitation occurred in May 1976 over large parts of Minnesota, Wisconsin, and Michigan and southeastward to Ohio, and by August only small parts of Indiana and Ohio had above normal rainfall. The pattern of deficient rainfall shifted continuously during the fall of 1976, and parts of Wisconsin, Illinois, and Ohio dropped below 25 percent of normal in November. Rainfall over most of the region increased to normal or above during February, March, and April 1977. Dry weather returned to Michigan and Wisconsin in May, 


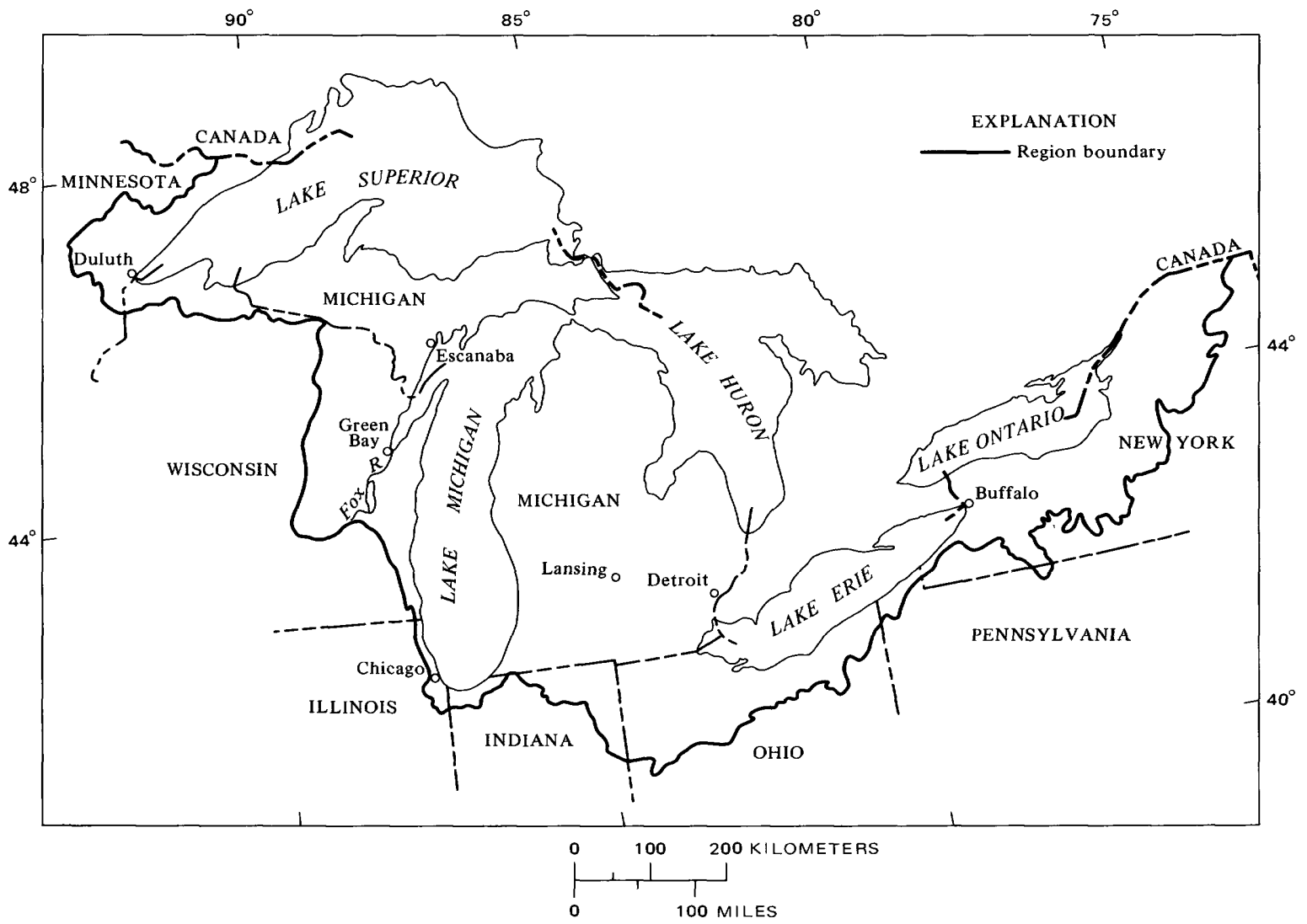

Figure 9. Great Lakes-WRC Region 04.

but rainfall for June through October 1977 ranged from 75 to 150 percent of normal.

The Palmer index (see figs. 6 and 7 ) reflects the precipitation distribution in time and space mentioned above and the fact that above normal precipitation did not always end drought conditions because agriculture is dependent upon rain at roughly weekly intervals as well as an adequate amount of rain. No significant rain fell in Wisconsin between April 15 and May 11, 1977. The Palmer index for the Upper Peninsula of Michigan dropped to -4 or lower in August 1976 and stayed near that for more than a year. Values this low indicate extreme drought conditions. Northern Wisconsin and northeastern Minnesota had Palmer indexes ranging from -4 to -9 at one time or another between August 1976 and August 1977.

Above normal temperatures during the summer of 1976 intensified the drought conditions primarily by reducing the soil moisture. Then the very low temperatures during the severe winter of $1976-77$ made it necessary to run water through pipes to keep them from freezing and further taxed the dwindling water supply and the pumping capacity of a few cities. Unseasonably high temperatures and strong winds the latter part of April 1977 in Wisconsin reduced the soil moisture to 25 percent of normal.

The low precipitation in 1976 , the very cold winter of 1976-77, and the continuation of below normal precipitation in 1977 were a series of events in which each succeeding event compounded the effects of the earlier events. Together they made the drought the most serious one in at least 50 years in Michigan, Minnesota, and Wisconsin.

The runoff pattern in Wisconsin reflected the precipitation pattern very closely. By early August 1976, the flows in the northwest basins had dropped to amounts that past records show have been exceeded 92 percent of the time. Flows in the Fox-Wolf River basin south and west of Green Bay were approaching the $10-y r$ low flow by late August 1976. 
The monthly average flows in the Fox River (fig. 10) dropped below the long term average for the month in June 1976 and remained below for 17 months through October 1977. Except for April and October 1977 during this same period, flow was in the deficient range. That is, it was among the lowest 25 percent of record which is defined by the lower quartile line in figure 10 . New minimum monthly averages for January and February in 80 years of record were reached in 1977 , and these were 69 and 81 percent of the previous minimums which occurred in 1965 and 1961 , respectively.

Runoff of the Sturgeon River at Sidnaw, Mich., $90 \mathrm{mi}$ northwest of Escanaba, was at new low amounts during the 1976 water year for periods ranging from 1 to 90 days. Probabilities ranged from 0.015 to 0.007 which are equivalent to recurrence intervals of 70 to 140 years.

The water levels of three lakes in Wisconsin during 1976 and 1977 were near average or above. In fact, the maximum levels for March, April, and May occurred in 1976 at Cedar Lake south of Green Bay at the end of above normal rainfall and runoff. Most of the minimum monthly levels in records almost 40 years long occurred either in 1948-50 or in 1958-59. The range in stage of these lakes is between 3 and $6 \mathrm{ft}$.

\section{Ground-water Conditions}

The surficial deposits of the Lake Superior drainage in Minnesota consist largely of thin drift over crystalline bedrock. Many wells are only 10 to $200 \mathrm{ft}$ deep and extend to a narrow zone where water collects on top of the bedrock. Therefore, the water supply from these wells is marginal at best and is vulnerable to drought. The State of Minnesota provided grants to 300 residents to deepen the shallow wells that went dry in four counties bordering Lake Superior.

In the Upper Peninsula of Michigan about 1,400 , mostly shallow, wells went dry. Many wells were deepened when a Federal loan could be obtained and a driller could schedule the work.

Only the northern half of Iron County, Wis., about $100 \mathrm{mi}$ east of Duluth, Minn., is in the Great Lakes Region, but countywide 121 private wells and 3 community wells either went dry or the yield was sharply reduced by December 1976. Permits for high capacity wells were granted to 512 of 515 applicants in Wisconsin.

Ground-water levels in Wisconsin were near normal after the winter of 1975-76 but they declined steadily through the summer and fall of 1976. They were near record low levels for the month by November 1976, and new minimum levels for the month were reached during 4 to 7 months of the 8 months between December 1976 and July 1977 because of the severe winter and because snowmelt during the spring of 1977 contributed but little recharge.

\section{Water Quality}

In southern Menominee County, Mich., about $40 \mathrm{mi}$ southwest of Escanaba, bad-smelling sulfurous water and increased salinity were the results of low water levels in the deeper wells.

The severe winter of 1976-77 reduced the flows in streams, and the ground-water discharge to the streams was not diluted as much by the low surface-water runoff. Therefore, dissolved-solids concentrations increased abnormally. Concentrations in the Cuyahoga River at Independence in northwestern Ohio almost reached $2,000 \mathrm{mg} / \mathrm{L}-50$ percent greater than ever measured before.

The residents of Hillman, in the northeast part of the Lower Peninsula of Michigan, had to boil their water because State officials thought there was a chance that ground water could enter their water system when the pressure was low.

\section{Activities Resulting from the Drought}

Small communities in the Upper Peninsula of Michigan had to resort to trucking water, and so did the city of Bessemer, population 2,800 . The Michigan National Guard and a unit of the State Police trucked water to some rural families. Water for drinking and cooking was obtained from schools or nearby communities where there was a firmer supply, and water for sanitary purposes was taken from lakes and streams.

Dry or low-yield wells in Wisconsin made it necessary to start trucking water in emergency situations on December $31,1976$.

Farmers in Menominee County southwest of Escanaba, Mich., raised funds to pay for 


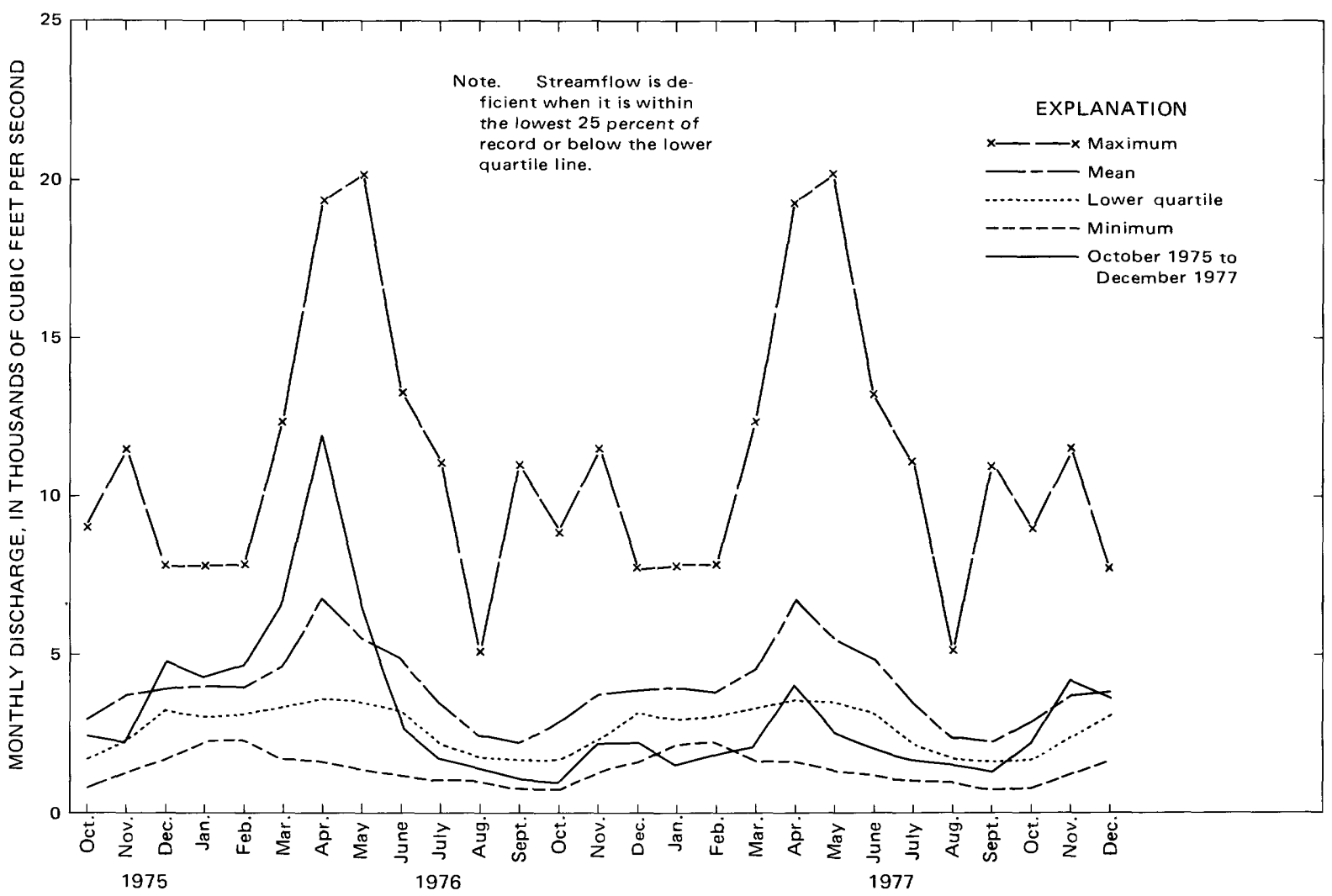

Figure 10. Monthly discharge of Fox River at Rapide Croche Dam, near Wrightstown, Wis.

cloud seeding between June 1 and August 17, 1977. Though there was some skepticism beforehand, the farmers were pleased with the results and are planning to use weather modification in the future.

In Wisconsin, 261 applications for water diversion permits were received statewide, but only 18 were granted. This shows that additional surface-water supplies were not readily available because of the low streamflow or because of prior water rights. The reliance on ground water for supplemental supplies was common as indicated by the 512 permits granted for high capacity wells.

Federal Community Development Grants totalling $\$ 625,000$ were made to five townships in Iron County, Wis., to rehabilitate or develop municipal water systems. But in other areas of Region 04 affected by the drought, the population density is so low that the development of water distribution systems was not feasible.

The impact of the drought was serious enough to allow 80 counties in Michigan, Wisconsin, and Minnesota to be designated disaster areas by the Federal Government. By the fall of 1976, farmers in 65 of Wisconsin's 72 counties had suffered crop losses and reduced income. Agricultural officials estimated the loss in 1976 at more than $\$ 623$ million. The Governor of Wisconsin appointed a Drought Task Force to advise him and to coordinate relief measures.

Wildfires in Wisconsin average about 2,000 to 2,500 per year and burn about 8,000 acres; but in $1977,1,811$ fires burned 48,000 acres. Most of the fires occurred during the first 6 months of 1977 when drought conditions were prevalent. The greater acreage burned by fewer fires is indicative of the extremely dry conditions. The largest forest fire in $\mathbf{4 0}$ years burned 16,500 acres in the Upper Peninsula of Michigan in August 1976.

\section{Upper Mississippi-WRC Region 07 and} Souris-Red-Rainy-WRC Region 09

The Upper Mississippi and the Souris-RedRainy Regions (fig. 11) include the northeast half of North Dakota, the northeast corner of South Dakota, all of Minnesota except the 




Figure 11. Upper Mississippi-WRC Region 07 and Souris-Red-Rainy-WRD Region 09.

southwest corner, the western two-thirds of Wisconsin, the eastern two-thirds of Iowa, most of nlinois, and small parts of Indiana and Missouri.

The 1976-77 drought in these two regions is briefly described as follows:

Central and northeastern Minnesota were the first areas where precipitation dropped significantly below normal. Most areas had deficient precipitation during most of the months from April 1976 to June or October 1977. Streamflow at many sites became less than that in the 1930 's, and new record low flows occurred for various periods up to 9 months. Peak discharges and the volumes of runoff were reduced, and water in storage was used to maintain flows.

Water supplies obtained from many wells failed or dwindled; therefore, water was hauled to rural areas and some towns and new wells were drilled. Water quality was affected in the Twin Cities area where amounts of dissolved oxygen were reduced to near or below the minimum standards set to maintain fish populations.

\section{Previous Droughts}

Palmer (1965) computed the Palmer index for central Iowa for the period 1930 to 1962 . 
According to his index, drought conditions existed 32 percent of the time, and extreme drought occurred 6 percent of the time. The most extreme conditions occurred during the 15-month drought from June 1933 to August 1934 when his index dropped to -6 ; but the longest drought period was 36 months from June 1955 to May 1958. The second lowest index value, -5.5 , occurred during the latter drought, but 16 of the 36 months were classed as extreme drought; whereas, only 5 of the 15 months of the earlier drought were classed as extreme. The Palmer index values are significantly higher than the value of -8 computed for the drought in 1976-77 (fig. 7b) which indicates that conditions in 1976-77 were worse than during the earlier droughts.

Palmer also computed his index for six counties in the Souris River basin in northwestern North Dakota between 1931 and 1962 . In this area, drought conditions existed 42 percent of the time, and extreme drought occurred 7 percent of the time. The lowest index, -6.7 , occurred during the 21-month drought from August 1933 to April 1935. This indicates that the drought of 1933-35 was more severe in this area than the drought of 1976-77 for which the minimum Palmer index was -5 . The longest drought lasted 47 months from October 1955 to August 1959. The earlier drought had 12 months classed as extreme and the latter drought had just 4 months classed as extreme.

October 1964 was very dry over both regions. There was no rain during the month near the eastern edge of Iowa near the IllinoisWisconsin State line. An all time record for minimum monthly precipitation was set at Burlington, on the Mississippi River in southeastern Iowa, where only 0.06 in. fell. Records for October were set at Moline, Peoria, and Cairo, Ill., where $0.01,0.03$ in. and a trace were recorded. Dubuque, Iowa, about $70 \mathrm{mi}$ southwest of Madison, Wis., also recorded only a trace; whereas the average for the month is 2.74 in. New minimum temperature records for several days were set at Madison, Wis.

The drought in Minnesota during 1976 was ranked as one of the four worst droughts since precipitation records began in 1891 (Upper Mississippi River Basin Commission, 1977). In 1910 the worst drought was in the southeast, in the northeast in 1934, in the northwest in 1936 , and in the west-central and southwest in
1976. Single very dry years occurred in Missouri in 1901 and 1947, but usually dry, or wet, years occurred in groups.

The Governor's task force in Wisconsin studied precipitation records at five locations in the State where records started in the 1870 's or 1880's (Upper Mississippi River Basin Commission, 1977). Precipitation was below 85 percent of normal at one or two locations in many years; but in only 6 years, 1895, 1910, $1939,1948,1958$, and 1976 was a drought almost statewide. About half the years since 1890 were below normal in some part of the State, and only three periods since $1871,1876-$ $84,1902-07$, and $1968-75$, had no years with less than 85 percent of normal precipitation. These records prove that meteorological droughts are fairly common occurrences in parts of Wisconsin, and even statewide droughts are not rare events.

\section{Precipitation and Runoff}

Annual precipitation in 1975 was above normal over both regions except for a band roughly $150 \mathrm{mi}$ wide with its axis running from Green Bay, Wis. to Kansas City, Mo. in which precipitation was between 75 and 100 percent of normal.

Precipitation in January and February 1976 varied radically in both time and space from less than 50 percent to more than 200 percent of normal. Above normal precipitation occurred in March with more than twice normal in several areas. The above normal pattern continued in April except for central and northeastern Minnesota where precipitation was less than 50 percent of normal. Much below normal conditions spread to North Dakota, Iowa, and Wisconsin in May 1976 and into Illinois and Missouri in June. Rainfall in July in North Dakota was less than 25 percent of normal. The pattern of deficient rainfall continually shifted and lasted through December 1976. A critical factor was the distribution of rainfall during the growing season as exemplified by data from Minnesota. The rainfall deficiency during April-August 1976 ranged from 2 in. in the north to 12 in. near the headwaters of the Minnesota River. Corn production was less than 20 bushels per acre where rainfall was less than 5 in. to more than 90 bushels per acre where rainfall exceeded 11 in. 
During January and February 1977 several parts of the regions received above normal precipitation whereas other parts had less than 50 percent of normal. Generally, March precipitation was above normal, but in April amounts less than 50 percent of normal fell in North Dakota and near the Illinois-Iowa border. Rains in May 1977 near the Souris and Red Rivers brought the monthly values up to more than twice normal, but most of Iowa had less than 75 percent of normal. June rainfall was still low in Iowa, and it was down to half normal along part of the Red River valley. Most of the two regions had above normal rainfall from July through November 1977 though southern Wisconsin had less than normal rainfall in September and October.

Soil moisture available to corn at Lamberton, Minn., about $115 \mathrm{mi}$ southwest of St. Paul dropped below average in July 1974 and remained below average through 1976 except for a brief period in June and July 1975 and was below or near the wilting point in August and September each year.

In Wisconsin, the soil-moisture deficit was as much as 15 in. for the last half of 1976 . The deficit was reduced in late February 1977 when about 1 in. of precipitation occurred. Though the ground was frozen, it had a honeycomb texture; therefore most of the precipitation entered the soil rather than producing runoff. The lack of soil moisture is vividly shown (fig. 12) by the parched soil in Iowa during 1976.

Records of streamflow were obtained 191117 and since 1928 on the Vermilion River near Tower in northeastern Minnesota. During the drought in the 1930 's, minimum daily discharges ranged from 31 to $34 \mathrm{ft} 3 / \mathrm{s}$, but there was virtually no flow during the spring of 1977 .

The index station on the lower Wisconsin River at Muscoda, $53 \mathrm{mi}$ west of Madison, Wis., has been operated for 64 years. Prior to 1976, minimum monthly flows occurred in seven different years between 1924 and 1964 . Three of the minimums occurred in 1934 and three in 1964. During the 1976-77 drought period five new minimum monthly flows occurred-in September through December 1976 and in May 1977. These 5 months were included in the 16 month period from June 1976 through September 1977 when monthly flows were below the median flows each month. The deficit amounts to 3.8 million

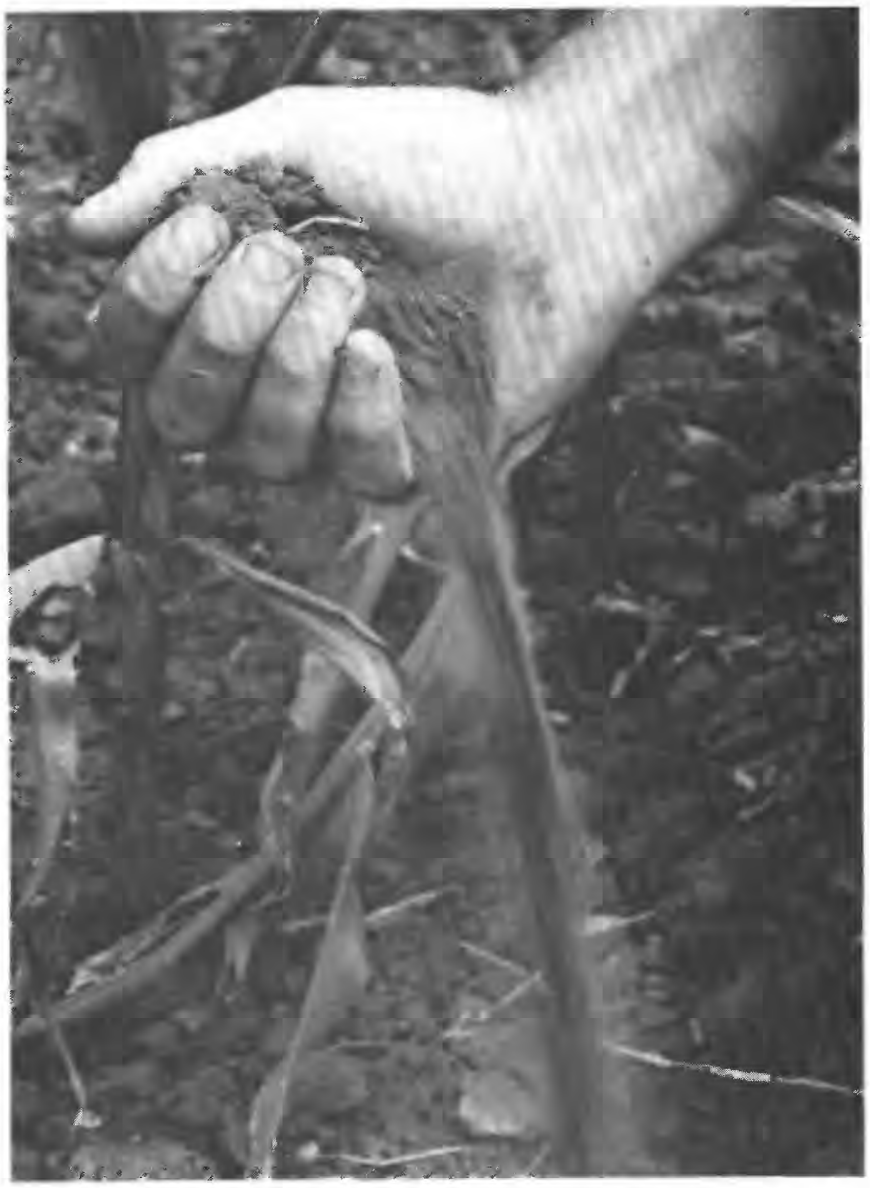

Figure 12. Parched soil in Iowa in 1976. Photo by R. J. Modersohn, Des Moines Sunday Register.

acre-ft or 49 percent of the average flow for the 16 months.

Local areas in Iowa were affected by drought in 1974, and conditions got worse in 1975 and 1976 until the driest 9 months of record occurred between May 1976 and February 1977. Streamflow decreased to the extent that it approached or became less than the 7day, 10-year low flow which is the minimum flow required by the water-quality standards before waste-water discharges can be made.

Illinois was affected by the drought but to a lesser degree than the neighboring States. Precipitation and streamflow were below normal, but timely rains during the 1977 growing season alleviated drought conditions. The low flows that occurred between October 1976 and July 1977 are not considered rare events.

Another effect of the drought besides reduced volumes of runoff is the reduction in peak discharges. Peak discharges on the Mis- 
sissippi River in $197 \overline{7}$ were about one-third those in 1976 in the headwaters, about onefourth near St. Paul, and 30 percent at lock and dam 10 nor theast of Iowa City.

The flow for the 1977 water year of the Red River of the North at both Grand Forks and Fargo, N. Dak., was the fifth lowest in 73 and 76 years of record and the lowest since 1935 or 1936 , respectively. The four lowest flows occurred between 1931 and 1936. The minimum flow of record occurred in 1934 when the flow at Grand Forks, 75 mi north of Fargo, was 49 percent and the flow at Fargo was 27 percent of that in 1977.

Changes in storage in 23 reservoirs in the Wisconsin River basin clearly show the effect of the drought. Normally, surplus flows are stored, usually in March and April and again in September and October; and water levels are held high through May, June, and part of July for the benefit of those engaged in waterrelated recreation activities. Storage usually is reduced in July and August and December through March primarily because of releases for hydroelectric power generation. The normal pattern occurred through August 1976, but the usual increase in storage in the fall did not materialize. Storage dropped to 21 percent of capacity at the end of October 1976 and to 6 percent of capacity at the end of February 1977. During the following months, the increase in storage was only about two-thirds of the increases that occurred in 1975 and 1976 . Because of the reduced storage, reservoir releases to the Wisconsin River during the summer of 1977 were cut back to half to twothirds of normal. This change in operation provided almost the normal amount of water in storage by late August 1977, and the following fall increase brought the storage up to 83 percent of capacity by November 13, 1977 .

Storage in six reservoirs in the headwaters of the Mississippi River decreased about 100,000 acre-ft during August 1976. The significant fact related to this decrease is that only 17,000 acre-ft was released to augment low flows in the Mississippi River and the rest was lost by evaporation. The Mississippi River flows were the lowest since the 1930 's, and regulation by powerplants reduced the flow at St. Paul to a new record low daily discharge of $530 \mathrm{ft} 3 / \mathrm{s}$ on August $31,1976$.

The water level in Coralville Reservoir on the Iowa River north of Iowa City, Iowa was 5 ft below its normal level from November 1976 to February 1977. Because of a forecast of continued below-normal precipitation, a meeting of water users was held at which all agreed to temporarily reduce the authorized minimum release from 150 to $100 \mathrm{ft} 3 / \mathrm{s}$. The reduced release was in effect from February 14 to March 18, 1977. Similar conditions prevailed in the Des Moines River basin, and the reduction of the authorized release from Red Rock Reservoir from 300 to $200 \mathrm{ft} 3 / \mathrm{s}$ was approved and was in effect from February 17 to March 17, 1977. Normal releases were resumed because the general rains across the State on March 11, 12 brought temporary relief to the drought areas.

\section{Ground-water Conditions}

Ground-water levels in Illinois were below average in May 1977, and maximum declines ranged from 2 to $11 \mathrm{ft}$. A few small communities had to obtain water from new sources, and many rural residents had to haul water when their shallow wells went dry or the yield was too low. A census of rural families that hauled water in January 1977 was taken in 49 of the 102 counties in Illinois, and 24,123 such households were found, and their average cost was about $\$ 40$. Extrapolation to the other 53 counties brings the estimated total cost to more than $\$ 1$ million. The per capita consumption dropped from about 100 to $37 \mathrm{gal} / \mathrm{d}$, a very low rate.

Most wells in the glacial drift in northern Wisconsin are shallow and recharge annually is necessary because the storage is limited. The low precipitation did not provide enough recharge mainly in northern Wisconsin and water supplies dwindled or failed. At least twice the usual number of permits for new irrigation wells was granted in 1976 and almost as many had been granted through May 1977. Even the cranberry bogs were short of water by December 1976 .

Generally, water levels in Wisconsin in unconsolidated formations, and in dolomite, sandstone, and granite, declined less than $3 \mathrm{ft}$, and lower levels have been recorded previously. Maximum declines in scattered wells were about $10 \mathrm{ft}$. Though neither the recharge to the aquifers nor the withdrawals from the aquifers are uniform, ground water is not being mined. 
Ground-water levels in two wells in Wisconsin, roughly $50 \mathrm{mi}$ northeast of St. Paul, Minn., had trends somewhat opposite the prevailing trends. At one well, new maximum levels in 21 years of record occurred from July 1975 through September 1976, and the water level stayed near the maximum levels through 1977. At the other well, a new maximum level for April was established in 1976, but levels dropped about $6 \mathrm{ft}$ between then and September 1977 when a new minimum level in a 12year record occurred. New minimum levels for the month were set for two to four months in 1977 in three other observation wells in Wisconsin.

In western Minnesota about 10 percent of the shallow wells went dry; and though water levels declined in the deep municipal and irrigation wells, the supply from them was adequate. In other parts of the State, the deficient rainfall and low soil moisture caused the farmers to take an intense interest in irrigation and to propose studies related to ground-water supplies. The increased pumping of ground water in Minnesota brought on problems of interference between wells in a few areas.

At the index observation well in southeastern North Dakota, water levels were at record low levels for each month from August 1976 to September 1977 except in April.

\section{Water Quality}

The low flow of the Mississippi River and the configuration of the Minneapolis water system combined to produce water with a mildly unpleasant odor for about 1 week in August 1976. The Minnesota Pollution Control Agency closely monitored the river water for possible adverse conditions that would affect the health of the public. No serious problem developed.

On the Mississippi River below the twin cities of Minneapolis and St. Paul, the dissolved-oxygen concentrations are usually low, but zero concentrations were observed by the Metropolitan Waste Control Commission's staff during the winter of 1976-77. At the Geological Survey station on the Minnesota River near Jordan, $30 \mathrm{mi}$ southwest of St. Paul, the dissolved-oxygen concentrations are about $10 \mathrm{mg} / \mathrm{L}$ most of the year with a sag to about 7 or $8 \mathrm{mg} / \mathrm{L}$ during some winters when ice cover exists. In February 1976, the concentration dropped to $6.2 \mathrm{mg} / \mathrm{L}$, and values for December 1976, January and February 1977 were $5.9,2.2$, and $5.8 \mathrm{mg} / \mathrm{L}$, respectively. Ice cover was a contributing factor in addition to the low flows which reduced the ability of the river to dilute the waste loading imposed upon it. To put the above values in perspective, among the criteria for dissolved oxygen set by the U.S. Environmental Protection Agency (1976) is a minimum concentration of $5.0 \mathrm{mg} / \mathrm{L}$ to maintain good fish populations. Field and laboratory observations indicate that feeding is diminished or stopped at $3 \mathrm{mg} / \mathrm{L}$ and below and that growth is less, even when the low concentration occurs for only part of the day.

\section{Activities Resulting from the Drought}

In Minnesota on lands under State jurisdiction, 3,470 fires burned 144,000 acres in 1976 and 180,000 acres were burned by 1,760 fires in 1977. The increased damage over the average of 1,000 fires and 50,000 acres is attributed to the drought. In addition, there were fires in National Forests and Indian reservations. A large part of Minnesota was closed to most outdoor recreation in October 1976 because of the high fire hazard.

The most serious fires in Wisconsin occurred during the first 5 months of 1977 including several grass fires and peat fires. To contain one of the peat fires, a large well was drilled and 90 million gallons of water was pumped in about 90 days.

Six cities in North Dakota have critical water problems which the drought has aggravated, and the drought has shown that 12 other cities have potential problems.

Both Minneapolis and St. Paul, Minn., divert water from the Mississippi River for their municipal water supply. St. Paul has several lakes that are used to store Mississippi River water and provide reserve supplies, but Minneapolis has no large storage in its system. In the summer of 1976, the Mississippi River dropped so low that the bottom of the intake for the Minneapolis system was only 5 in. under water. If the river stage had fallen below the intake, a secondary intake could have been used, but the city would have only a 24-hr supply unless emergency actions were taken. Since then, the city has had a feasi- 
bility study made for a supplemental supply of ground water, but has had no success.

The reduced releases from storage in the Wisconsin River basin in the summer and fall of 1976 and in the summer of 1977 caused some periods of inefficient hydroelectric power generation which affected the operations at the paper mills that rely mainly on hydroelectric power; therefore, the price of paper went up. The low flows were also detrimental to the tourist business, water recreation, and fishing. The below normal runoff into reservoirs and lakes meant lower water levels, and the owners of lakefront property complained. A drop of only a few feet in shallow lakes in Minnesota and Wisconsin is enough to expose large amounts of land normally under water. The length of Lac Qui Parle in Minnesota was $1 \mathrm{mi}$ shorter in the fall of 1976 than it was in the spring.

The lower than usual lake levels and the low flows in streams in Iowa combined with the extra thick ice cover during the very cold winter of 1976-77 caused numerous fish kills. Statewide, water-supply problems were aggravated in 28 communities, some rural wells went dry in 56 of the 99 counties, and about 11 percent of the farmers had to haul water. The demand for permits for irrigation water increased from about 40 per year to more than 550 in 1976 and created a large backlog which triggered complaints from the applicants.

Many wells that provided water for domestic use in rural areas in Illinois went dry, and water had to be hauled. Secondary effects are the lowering of property values because of the poor water supply and the possibility of increased rates for fire insurance because of the reduced amounts of water in stock ponds that can be used for fire fighting.

Cloud seeding was tried by farmers in Coles County, Ill., about $170 \mathrm{mi}$ south of Chicago; they claimed positive results.

The added cost of hauling water for livestock and dairy herds was enough to force some reductions in the number of cattle maintained and to put out of business a few producers who were operating on a marginal basis.

Crop acreage in Minnesota was reduced, and losses to the farmers in 1976 was estimated as $\$ 1.45$ billion. Though corn acreage fell 300,000 acres, wheat acreage increased 1.2 million acres in 1976. Some acreage in
Iowa usually planted in corn was planted in soybeans which thrive a little better than corn in a dry year. Also, the density of corn planted was reduced 5 to 10 percent on a few farms to make more moisture available to each plant.

Disaster designations were obtained by 185 counties in six States, and the governors of several States appointed special task forces to deal with drought problems.

\section{Missouri Basin-WRC Region 10 (upper part)}

The Missouri Basin has been divided into the upper and lower parts for this report because the basin is too large and the drought conditions too varied to treat as a single unit. The upper Missouri basin (fig. 13) for the purposes of this report includes all of Montana east of the Continental Divide, the southwest half of North Dakota, all except the nor theast corner of South Dakota, and that part of Wyoming east of a line roughly through the southwest quadrant of Yellowstone National Park to Rawlins.

A recapitulation of the salient features of the 1976-77 drought follows.

Most of the region had the most severe drought in this century with precipitation in some areas as low as 25 percent of normal for several months. April 1977 was the second driest April in 98 years in Montana. Runoff was very low, and storage in reserviors was reduced to record low levels.

Ground-water levels generally declined, and many new wells increased the withdrawals of ground water. Water quality was adversely affected locally, and some changes in operations of water systems were made to forestall other water-quality problems. Water rationing was in effect in several cities.

Previous droughts in the 1930's were described by Hoyt $(1936,1938)$. Water years with low runoff over parts of the region include $1919,1921,1931,1934,1936-41,1944,1951$, 1954-61, and 1966. This indicates that drought conditions are quite common in the region and that the severity and length of a drought are the main factors that distinguish one drought from another. 


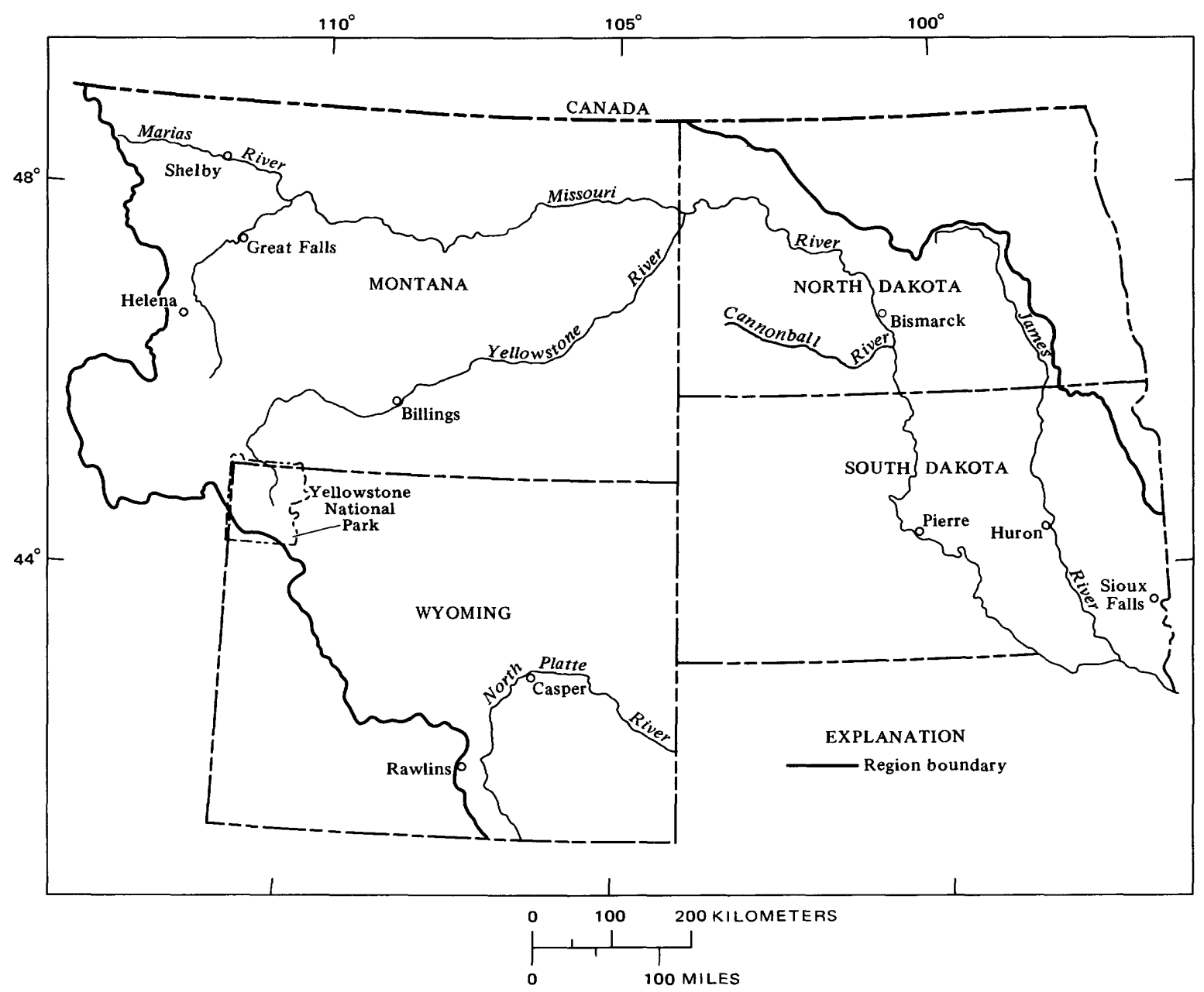

Figure 13. Missouri basin-WRC Region 10 (upper part).

Precipitation and Runoff

Precipitation during 1975 was above normal over the region except in the southeast corner of Wyoming and most of southern South Dakota where precipitation was between 75 and 100 percent of normal.

The above normal precipitation continued through April 1976 over most of the region though parts of all four States had below normal precipitation at one time or another between January and March 1976. May precipitation was below normal over all the region except for a small band across southeastern Wyoming. During the summer of 1976 rainfall was generally below normal-as low as 25 percent of normal in the Dakotas in July-even though several localized areas showed much above normal precipitation. During the last four months of 1976, precipitation continued to be below normal. In South Dakota, the annual precipitation during 1976 in the western part of the State was about normal, while in the eastern part deficiencies ranged from 6 to 13 in. or about 30 to 65 percent of normal. The drought of 1976 was considered to be the most severe during the 20th century in much of this region.

Monthly precipitation in both January and February 1977 was less than 2 in. over the entire region. March precipitation ranged from less than 1 in. in parts of Montana, North Dakota and Wyoming to more than 4 in. in south-central South Dakota. The latter amount was five times normal for March. April 1977 precipitation was deficient over most of the region; in fact, in Montana, April 1977 was the second driest April in 98 years of record. Good rains fell in May over the areas that were below normal in April, and rainfall was 
subnormal again in June over most of Montana and Wyoming. Except for an area in northern Montana, rainfall in July and August was generally above normal. The same was true for September, but the deficient area moved to Wyoming. Precipitation for the rest of the year was mostly above normal, but monthly amounts were generally less than 2 in.

The water content of the snowpack in the vicinity of Helena, Mont. was only 10 percent of normal on May 1, 1977 and presaged very little runoff for the usual snowmelt period in May and June.

Soil moisture, in both the topsoil and in the subsoil, was deficient in most of the counties in North Dakota during April 1977. Rains early in May in South Dakota brought topsoil moisture up to "adequate." Mid-June rains in southwestern North Dakota increased the soil moisture to more than it had been in over a year.

By mid-March 1977, flows in the Yellowstone and Marias Rivers in Montana and the Cannonball River in southwestern North Dakota had receded to the below normal range. Abnormally heavy rains in South Dakota in March increased the flow of the James River at Huron from zero to $1,700 \mathrm{ft} 3 / \mathrm{s}$. There had been no flow at Huron since July 1976, the longest period of no flow since the 10-month stretch in 1959-60. Flow ceased again early in May 1977 and did not occur again until late December, another no-flow period of almost 8 months. The James River is regulated; therefore, the long periods of no flow at Huron reflect the increased needs for diversions upstream. Warm weather late in April 1977 increased the snowmelt runoff enough in Montana to bring streamflow up close to normal or above normal and brought storage in most reservoirs above normal for May 1. Most streams in Montana peaked about a month earlier than usual because of the poor snowpack.

The flow of the Marias River was down to 16 percent of normal in May. Flow of the Cannonball River for the first 7 days of June was down to only 3 percent of the normal for June, but heavy rains of up to 7 in. in southwestern North Dakota during the following week increased the average flow from $7 \mathrm{ft} 3 / \mathrm{s}$ to $340 \mathrm{ft} 3 / \mathrm{s}$ which is 125 percent of normal.

Monthly flows for June 1977 of the Yellowstone River at Corwin Springs just north of
Yellowstone National Park were the lowest since 1941 and at Billings they were the lowest since 1934. Monthly and minimum daily discharges on the Marias River near Shelby in June were the lowest since records began in 1911. Very high temperatures during the first half of July and below normal rainfall reduced flows in many Montana streams to near record lows.

Storage in Fresno Reservoir on the Milk River in north-central Montana decreased to 35 percent of normal in May 1977 which was the lowest for May since 1961. Only May 1941 was lower. By mid-July Fresno Reservoir storage was down to 14 percent of normal. Contents in many reservoirs in Montana set or were near record lows by the end of July. Some of the records start between 1930 and 1947.

A small pie-shaped part of Montana near Glacier National Park is actually part of the Saskatchewan River basin, but it has been included as the northwest corner of this region. Usable contents of Lake Sherburne in Glacier National Park were depleted by mid-July 1977 . Normally the July contents are near 55,400 acre-ft. Contents increased by mid-August to 5,300 acre-ft which is 20 percent of normal for August.

\section{Ground-water Conditions}

The general pattern of changes in groundwater levels was one of decline in 1976 and much less than the usual recovery or no recovery in the following winter and spring. The decline continued in the summer of 1977 in some wells but not in others. More permits than usual were issued for new wells, and ground-water withdrawals increased in both 1976 and 1977.

Records for a well in western North Dakota started in 1968, and a new record low level was reached in May 1977 when the water surface was $18.7 \mathrm{ft}$ below land surface and 0.3 $\mathrm{ft}$ lower than the previous low of record which was in 1969. This well reacts quickly to rainfall; therefore the rains in June 1977 raised the water level $1 \mathrm{ft}$, and it remained well above previous minimum levels for the rest of the year.

A large increase in irrigated acreage occurred in South Dakota between 1976 and 1977 when dry land acreage was converted. Deep 
wells and pivot-irrigation systems were installed, and the use of ground water increased. In 16 counties east of the Missouri River the irrigated acreage increased 37 percent. In Beadle County, near Huron, 87 new wells in 1977 represented an increase of 78 percent over the number operating in 1976. The deep artesian aquifers were not affected by the drought, but record low water levels for periods of up to 25 years were recorded in 86 of 128 observation wells in the glacial drift in eastern South Dakota late in 1976 or early in 1977. Record low water levels for the last 14 years occurred in 18 of 19 wells in the alluvium of the Big Sioux River valley in the southeast corner of the State during the winter of 1976-77.

\section{Water Quality}

On June 21, 1977, a highly toxic concentration of bluegreen algae was found in the Grayling Arm of Hebgen Lake on the Madison River just west of Yellowstone National Park. The deaths of 7 dogs and 27 cattle were reported, but no ill effects were reported by humans. The algae bloom was apparently caused by the low local inflow into the Grayling Arm which resulted in a rise in water temperature of the shallow water and by some inflow from the Madison River which has a higher nutrient load. The toxic condition disappeared naturally by August 1, 1977. Minor algae blooms were reported in Ennis Lake downstream from Hebgen Lake in late August and early September 1977.

Outflows from several reservoirs in Montana, including Fresno Reservoir, were reduced in August 1977 to eliminate potential waterquality problems during the winter by storing as much water as possible. A shallow lake that is frozen may develop low levels of dissolved oxygen because of the uptake by sediments, and hydrogen sulfide problems and fish kills may ensue. Also, if lake levels are not high enough, spawning areas may be exposed and the fish population will decrease.

Changes in water quality in aquifers were not observed; however, the sampling programs are not extensive.

\section{Activities Resulting from the Drought}

At Mitchell, S.D., about $50 \mathrm{mi}$ south of Huron, water was pumped from the James
River into the city reservoirs in April 1977, Aberdeen north of Huron, and Sioux Falls restricted water use, and Huron officials started plans for a well field to supplement their supply which is obtained from the James River at a diversion dam upstream. Diversions for nonmunicipal uses from the James River upstream from Huron were curtailed in May 1977 in an effort to preserve municipal supplies, and Mitchell initiated water restrictions.

Great Falls, Mont., began water rationing on July 7, 1977; the 10 percent reduction was mandatory. Red Lodge, southwest of Billings, Mont., followed suit in mid-July.

A lightning strike in tinder dry grassland and timber east of Billings burned 2,300 acres in July 1977. Because of the drought and temperatures of $90^{\circ}$ to $100^{\circ} \mathrm{F}$ the fire danger remained high for most of the summer.

Seventy-seven counties in three States were designated as disaster areas because of the drought.

\section{Missouri Basin-WRC Region 10 (lower part)}

The lower part of the Missouri Basin (fig. 14) includes the State of Nebraska, the northeast quarter of Colorado, the northern half of Kansas, most of western and northern Missouri, the western quarter of Iowa, and the southwest corner of Minnesota.

The 1976-77 drought in this region is summarized as follows:

The drought was at its worst in Kansas and Nebraska in 1976, but 1977 was the worst year in Colorado and Missouri. Runoff of a number of streams with long-term records reached record low values, and storage in most reservoirs was below normal.

Many new wells were drilled, ground-water levels declined, and ground-water mining was accelerated in western Kansas, but no major water-quality problems arose either in the aquifers or in the streams.

Water restrictions were implemented in a few areas, and weather modification was tried because of the increased demand for irrigation water.

Overall the drought was not as severe as those in the 1930's and 1950 's, but it was bad enough to affect the lives of both rural and urban citizens. 


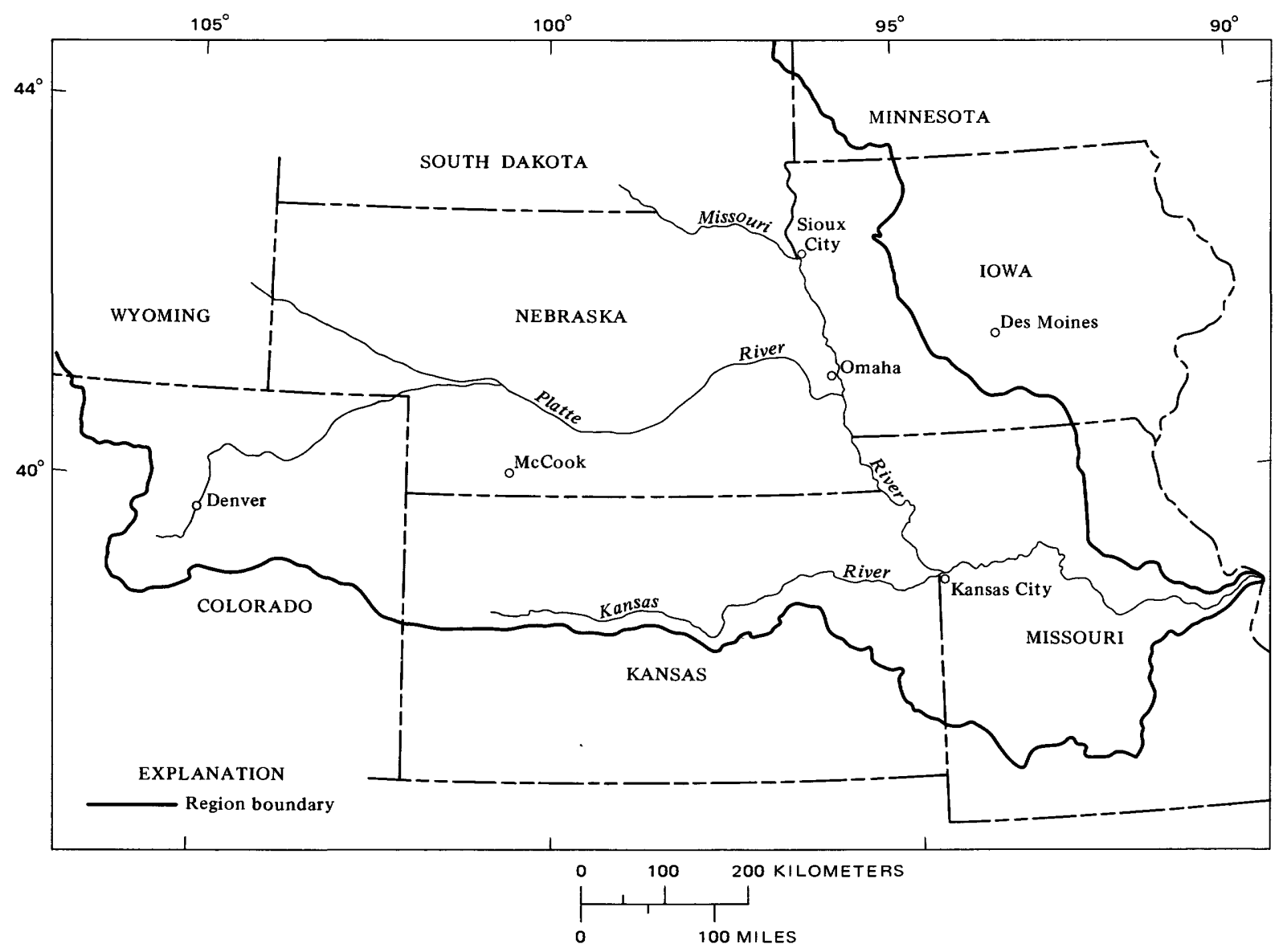

Figure 14. Missouri basin-WRC Region 10 (lower part).

\section{Previous Droughts}

Drought is not a rare event in this part of the Missouri basin. Hoyt (1936, 1938) described the drought conditions of the 1930's. Palmer (1965) tabulated his index values over a 76-year period from 1887 to 1962 . His index shows that drought conditions existed 37 percent of the time in western Kansas and occurred during 28 different periods. He classified 8 percent of the months in the 76 year period as severe drought and 6 percent as extreme drought. The median duration of drought is about 4 months, but the average duration is 12 months. The longest drought was 99 months from August 1932 to October 1940, but the lowest Palmer index, -6.2, occurred during the second longest drought, 57 months from June 1952 to February 1957. See figures 6 and 7 for Palmer index values in 1976 and 1977.
Drought periods of different lengths and severity occurred in 1952, 1953, and 1954 through 1956. Southwestern Missouri was very dry from May 1952 through 1956, and one person aptly dubbed this period "The Big Dry" because it was worse than the drought of the 1930's.

\section{Precipitation and Runoff}

Statewide, precipitation in Iowa from May through December 1976 was the lowest in 104 years. Iowans claimed that they liked to stand in the fields and listen to the corn grow, but one wag said that in 1976 they listened to it gasp for water! Another said that the rain was so spotty that one barrel of a double-barreled shotgun leaning against a fence filled up with rainwater, but the other barrel stayed dry! From other reports, the latter story is not as much of an exaggeration as it first appears to be. 
The drought in Kansas was at its worst in 1976. The heavy rains in June 1977 ended the drought in eastern Kansas, and by September 1977 enough rain had fallen that it was considered over in central and western Kansas. Similar conditions were reported in Nebraska where soil moisture was inadequate.

The water content of the snowpack in the Rocky Mountains of Colorado on April 1, 1976 was 99 percent of normal, but 1 year later it was only 45 percent of normal for that date. By early May 1977 the remaining snow was only at the higher elevations and represented only 21 percent of the normal water content. Timely rains during the summer of 1977 in eastern Colorado provided enough moisture to maintain crops at least at average production.

In mid-March 1977 the flow of the Nishnabotna River above Hamburg, Iowa, about 45 mi south of Omaha, Nebr., was down to 20 percent of the median flow for March. The monthly mean flow for April of the Grand River at Gallatin, Mo., $65 \mathrm{mi}$ north of Kansas City, was 13 percent of the median flow. Flow for the first half of June was down to less than 1 percent of normal.

April 1977 was the eighth consecutive month that streamflow was in the below normal range in Kansas. Significant precipitation, 4 to 6 in., over the western third of Kansas late in April improved the soil moisture conditions and did increase streamflow in north-central Kansas. Soaking rains in early May over most of the region caused very little increase in runoff, and storage in reservoirs remained below normal. The rains did reduce the demand for irrigation water, however.

By mid-May, Kanapolis and Tuttle Creek Reservoirs in central Kansas were at or very near their conservation pool levels, but four reservoirs to the west were still well below conservation pool levels. These four were still about $20 \mathrm{ft}$ below in July.

In June 1977, two streams in the Nebraska panhandle reached new minimum flows in 33 and 39 years of record.

The effect of the low snowpack in the Rocky Mountains is reflected in the flow of St. Vrain Creek north of Denver, Colo. Monthly flows from January through July and again in September 1977 were among the lowest 25 percent of 86 years of record. The most significant aspect of this statistic is the length of time, 8 of 9 months, that the flow remained so low.

\section{Ground-water Conditions}

The water table in western Kansas dropped an average of $3.5 \mathrm{ft}$ in 1976 which is greater than the average decline during the previous 10 years. By June 1977, water levels at many sites were at or near record low levels.

Nebraska registered about 60 new irrigation wells per week in May 1977, and the total reached 2,600 by July 1 . Water levels in the Platte River Valley of Nebraska in May 1977 were 1 to $4 \mathrm{ft}$ lower than the year before, but by the end of June water levels were near or slightly above long-term average levels in the central and west-central parts of the State. In eastern Nebraska, water levels remained $1 \mathrm{ft}$ or more below 1976 and $2 \mathrm{ft}$ or more below the long-term average levels.

There are only a few areas in Iowa where ground water can be pumped in quantities sufficient for crops. During May in Iowa, ground-water levels declined more rapidly than usual, enough to make people concerned, and by mid-June had reached levels that usually occur in the fall.

The heavy withdrawals in western Kansas accelerated the mining of the ground-water resource. Temperatures exceeding $100^{\circ} \mathrm{F}$ and strong winds made irrigation imperative and increased the demand on a stressed resource. Similar weather conditions in Nebraska brought the same result.

\section{Water Quality}

Early in May 1977 concentrations of dissolved solids and of chloride in the Smoky Hill River at Enterprise in east-central Kansas exceeded $1,300 \mathrm{mg} / \mathrm{L}$ and $400 \mathrm{mg} / \mathrm{L}$, respectively. The maximum chloride concentration recommended for drinking water, $250 \mathrm{mg} / \mathrm{L}$, was almost reached in the Kansas River, but timely rains and increased releases from storage reduced the concentrations to acceptable levels.

The first significant runoff in streams that had been dry or virtually dry carried heavy concentrations of dissolved solids and organic materials. This effect was localized, and the overall effect on water quality was minimal. 


\section{Activities Resulting from the Drought}

Dry soil conditions in May 1977 in the Niobrara River basin in northwestern Nebraska triggered an early start by irrigators. Irrigation water distribution in the North Platte River system in Nebraska was changed to an allocation basis in an attempt to extend the available supplies over a longer period. The State restricted diversions from streams in western and southeastern parts of the State.

Ordinarily low flow in lowa occurs in September, but under drought conditions low flow occurred in July. Therefore, the Geological Survey made many low-flow measurements to help define the drought-related hydrology of the State.

Water restrictions were started in June 1977 by Thornton, Colo., a Denver suburb. By mid-June, Corning, in southwestern Iowa had less than a 90-day supply in its reservoirs and started water rationing. Serious water shortages developed in other small cities in western Iowa.

Missouri was plagued by a grasshopper invasion, probably increased by the drought conditions which one agency stated were the worst since the 1930's.

Comparative figures of corn production in Iowa are interesting. In the drought years 1934 and 1936 average corn yields were 28 and 20 bushels per acre, respectively. The average was 52 bushels per acre for 4 years during the drought of 1952-56, and the first 100-bushel year was in 1971. The drought in 1976 cut production to 90 bushels per acre, still a respectable figure. The relatively high production during a severe drought is an excellent testimonial for today's improved seed corn and farming methods.

A new word was coined to describe the winter conditions during the drought. Winds not only blew snow into drifts as is common in the winter, but the dry soil was blown along with the snow. The resulting mixture was called SNIRT, a very descriptive word.

The drought was severe enough in five States to justify disaster designations for 85 counties. Task forces or committees were appointed by the governors of several States to coordinate drought related activities.

\section{Arkansas-White-Red-WRC Region 11}

The Arkansas-White-Red Region (fig. 15) includes the southeast quarter of Colorado, the southern half of Kansas, the northeast corner of New Mexico, the Texas panhandle and a strip of Texas south of the Red River, all of Oklahoma, southwestern and south-central Missouri, most of the west half and northcentral Arkansas, and the nor thwest corner of Louisiana. The drought affected Colorado, Kansas, and Missouri, and the rest of the region was on the fringe with some relatively minor effects locally at times.

A synopsis of the 1976-77 drought is presented first. Precipitation was less than 50 percent of normal in parts of the region at various times, but the number of consecutive months that this condition occurred was less than in some of the other regions. The abnormally low snowpack in the Rocky Mountains was the reason extended periods of deficient runoff occurred on the Arkansas River. Storage in reservoirs was reduced or even depleted. The high withdrawals of water for irrigation brought about declines in groundwater levels and the continued mining of ground water in western Kansas. Groundwater quality was not affected, and water quality problems in streams were localized and shortlived.

Weather modification was tried in western Kansas, a few towns had to haul water or install emergency pipelines from another source, and a moratorium was imposed on new wells near the Arkansas River west of Garden City, Kans.

Previous droughts have been described by Hoyt $(1936,1938)$ and by Nace and Pluhowski (1965). Brief descriptions presented in this report in the section for the Missouri BasinWRC Region 10 (lower part) are generally typical of Region 11. See page 36.

\section{Precipitation and Runoff}

Precipitation in the region during 1975 ranged from 75 to 125 percent of normal, and only small areas were at either extreme.

The deficient precipitation trend started in December 1975 , and precipitation was less than 50 percent of normal over most of the region in January 1976. The percentages of normal improved in February and March, but 


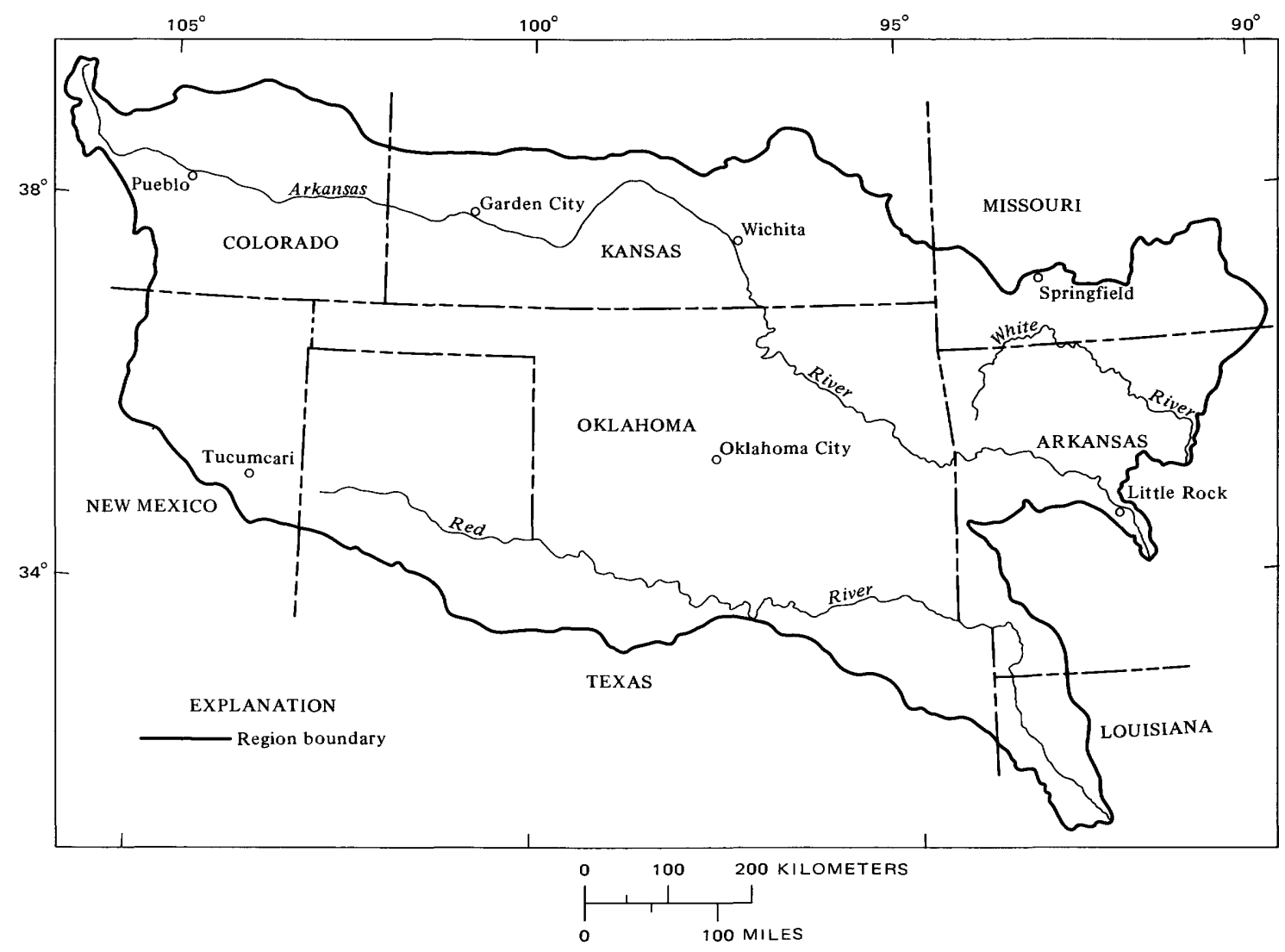

Figure 15. Arkansas-White-Red-WRC Region 11.

total monthly amounts of precipitation in Kansas and Missouri were small, less than 3 in. April precipitation was well above normal over most of the region, but May, June, and July rainfall was less than 50 percent of normal near the Colorado-Kansas State line and in the Oklahoma and Texas panhandles. The less than 50 percent of normal area centered around the Kansas-Oklahoma State line in August 1976 and shifted to Missouri in September. Precipitation in October was quite varied, but that in November and December was less than 25 percent of normal over major parts of the region and less than 50 percent of normal over almost all of it.

Deficiencies of precipitation in the Rocky Mountains of Colorado and in and adjacent to southwestern Kansas continued through March 1977. Large parts of the region had above normal rainfall April through July, but small areas below 50 percent of normal precipitation persisted in Oklahoma, Colorado, near the Oklahoma panhandle, and in Missouri. August precipitation was above normal everywhere except in New Mexico and Arkansas. The August precipitation in Missouri was sufficient to provide adequate soil moisture and lessen the threat of a severe drought during the late summer and fall. Rains in eastern Kansas during the same period diminished the severity of the drought there. September and October were generally dry and a wet period returned in November 1977.

Monthly flows in the Arkansas River at Canon City, about $35 \mathrm{mi}$ west of Pueblo, Colo., dropped into the lowest 25 percent of the monthly flows in December 1976 and stayed that low for 17 months. The first half of this recession was caused by the low runoff from the much below normal snowpack in the Rocky Mountains, and the rest by that plus the increased diversions for irrigation. All time monthly low flows since records started 89 years ago occurred in May and August 1977.

At Dodge City, $50 \mathrm{mi}$ east of Garden City, Kans., the Arkansas River was dry for 212 days from September 21, 1976 to April 20, 1977, the longest period of no flow on record. Intermit- 
tent flow occurred on a few days a month from May through September 1977. Previous periods of no flow were a few days in 1954,1956 , and 1974,44 days in 1946, 61 days in 1903, and 86 days in 1975 .

Intermittent streams in Missouri went dry earlier than usual, some in May 1977. Flows in other Missouri streams were generally below normal.

Lake McKinney is an of fstream reservoir west of Garden City, Kans., that receives water from the Arkansas River. It had been dry for short periods before 1977, but it dried up early in May 1977 and stayed dry for about 1 year.

\section{Ground-water Conditions}

The most serious problems related to ground water occurred in southwestern Kansas. Because the winter of 1976-77 was dry, soil moisture was low; and farmers began irrigating early in March 1977. This drain on the aquifers followed an average water-level decline of $5 \mathrm{ft}$ in 1976. Water levels continued to decline until May 1977 when rains reduced the need to pump ground water. Steady conditions lasted about 1 month when renewed pumping started another decline so that by July 1 new record low water levels were established. High temperatures and strong winds made irrigation imperative, and the downward trend continued into the fall of 1977. The average decline in 1977 was $3.7 \mathrm{ft}$. The downward trend indicates that the mining of ground water in southwestern Kansas continues. Summer rains in eastern Kansas brought water levels up slightly.

\section{Water Quality}

Some pumps east of Lake McKinney in south-western Kansas were damaged by electrolysis. One explanation is that highly mineralized water from the Arkansas River that had been stored in Lake McKinney leaked into the underlying aquifer and affected the quality of the ground water.

Fairly heavy rains in May 1977 at several locations in Kansas caused the first rise in several months on streams. High concentrations of dissolved solids and organics were present for short intervals, and eroding stream banks were factors locally. The overall effect of the drought on stream water quality was minimal.

Though there was a large overdraft of ground water in western Kansas, no widespread effect on ground-water quality was reported.

\section{Activities Resulting from the Drought}

The severity of the drought in Missouri varied continuously, both in time and from place to place, but several towns started investigations of possible nearby water sources to supplement their diminishing supplies.

The dwindling ground-water supply in western Kansas was the reason that the Kansas State Board of Agriculture imposed a moratorium on new wells near the Arkansas River in two counties west of Garden City. A better definition of the stream-aquifer system is proposed before the moratorium is rescinded.

Natural gas is the energy source used for many irrigation pumps in Kansas. The combination of higher prices for natural gas, the increased pumping required because of the drought, and declining farm prices caused economic hardships.

A few towns in eastern Kansas had to haul water or install pipelines from other sources of water as short-term emergency measures.

Cloud seeding was done in western Kansas in July and August 1977. Seeding was done three times during a week in August, but results were uncertain as rain fell that week over most of the State.

Disaster designations were obtained by 82 counties in 5 States.

\section{Upper Colorado-WRC Region 14}

The Upper Colorado Region (fig. 16) consists of western Colorado, eastern Utah, the Green River basin in Wyoming, and small parts of Arizona and New Mexico near the Four Corners area. The division point between the upper and lower Colorado River basins is 1.0 mi downstream from the Paria River near Lees Ferry, Ariz.

A digest of the description of the drought of 1976-77 in the Upper Colorado Region follows.

The deficiency of precipitation did not become widespread until September 1976. Precipitation continued to be deficient most of the time during the next 9 months. The water 


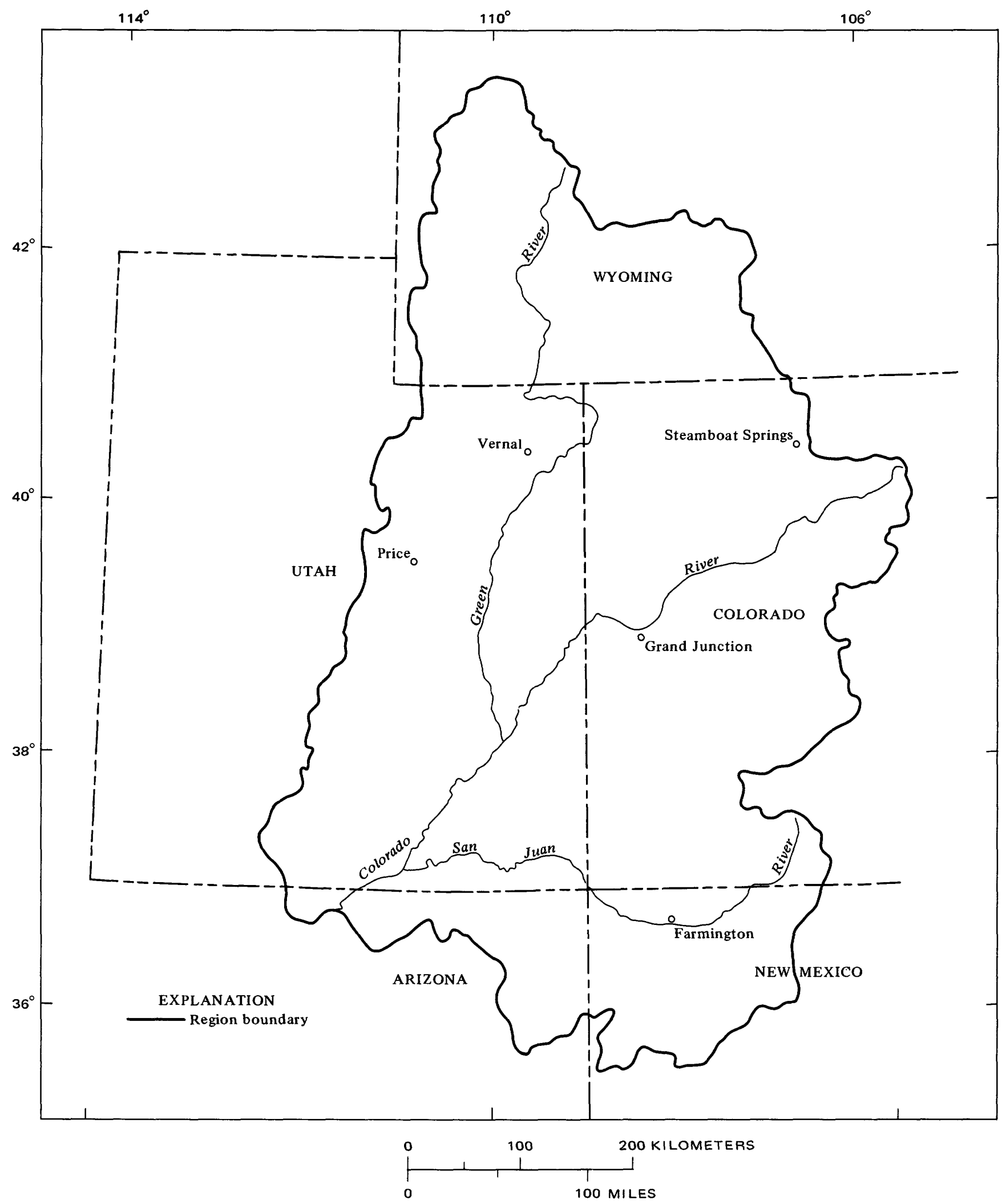

Figure 16. Upper Colorado-WRC Region 14. 
content of the poor snowpack in 1977 ranged from 20 to 45 percent of normal in March, April and May.

Below normal runoff occurred in all but one or two months in periods as long as 18 months, and flows were generally less than those in 1934. New low records were set for daily, monthly, and annual flows. Storage in reservoirs was severely reduced.

Withdrawals of ground water increased by as much as 60 percent, many new wells were drilled, and water levels declined in several areas. Changes in water quality of either ground water or surface water were not significant. Water use was restricted in several communities.

The Upper Colorado Region was affected by drought from 1931-35. The effect was more pronounced in the lower part of the Colorado Plateau and in the Gunnison River valley in Colorado southeast of Grand Junction than in the San Juan River basin (Thomas and others, 1963d).

The average precipitation in Colorado and in Utah for the 5-year drought was 85 percent of normal. That for 1934 was 66 percent of normal in Colorado and 74 percent in Utah. The year 1933 was the warmest in 32 years in Colorado, but 1934 was even warmer with an unusual departure of plus $4.5^{\circ} \mathrm{F}$. A similar departure was observed in Utah.

\section{Precipitation and Runoff}

Precipitation during 1975 was slightly below normal in the lower part of the region and normal to about 115 percent of normal in the upper part of the region. Monthly precipitation in 1976 exhibited a continually changing pattern ranging from less than 50 percent to more than 150 percent of normal for one month or another over most of the region. The lower values started to be typical of larger parts of the region in September 1976 and were representative of most of the region by December 1976 .

The below normal pattern of precipitation that started in the latter months of 1976 continued over most of the region through February 1977. Some slight relief occurred in March 1977 when precipitation was above normal in the upper Green River basin, but the total precipitation for the month was small, less than about 3 in. The drought conditions became more severe in April when precipitation ranged from about 40 to 75 percent of normal. Additional precipitation in May improved the situation, but it deteriorated again in June. During the rest of the year precipitation vacillated above and below normal over most of the region.

The snowpack was poor in the eastern third of Utah where the water content on March 1 , 1977 was 20 percent or less of normal except in the Fremont River drainage, south of Price, where the water content was about 50 percent of normal. By March 1, the snow water content should be about 87 percent of the total for the season.

Of the 82 snow courses in Colorado, 8 were bare and 15 had less than 5 in. of water on May 1, 1976. Comparable figures for 1977 are 38 bare and 23 with less than 5 in. of water. Based on 76 snow courses, the water content of the snowpack on April 1, 1976 was 99 percent of average and that in 1977 was 45 percent of average. The remains of the light snowpack in Colorado in 1977 were only at the higher elevations by early May and had only 21 percent of the normal water content. What snow had melted sustained streamflow at only about 50 percent of normal.

The difference in the areal extent of the snowpack in part of the Upper Colorado River and the Upper Missouri River basin between 1976 and 1977 is depicted in figure 17. The snow cover in April 1976 is shown in figure 17a, and that in April 1977 is shown in figure 17b. The photographs were obtained from Landsat satellite imagery and cover an area approximately $115 \mathrm{mi}$ on a side.

Steamboat Springs and Rabbit Ears Pass, Colo., are near the center, the White River basin is near the lower left corner, the Yampa River is in the left center, the North Platte River valley is between the north-south trending ranges of the continental divide and the Medicine Bow Mountains in the upper right quadrant, and the headwaters of the Laramie River in Wyoming are near the upper right corner.

Monthly flows at two index stations in western Colorado, the Animas River at Durango, south of Grand Junction, and the Yampa River at Steamboat Springs, indicate the severity of the drought. Monthly flows of the Animas River dropped below normal in November 1976, and except for August and Septem- 


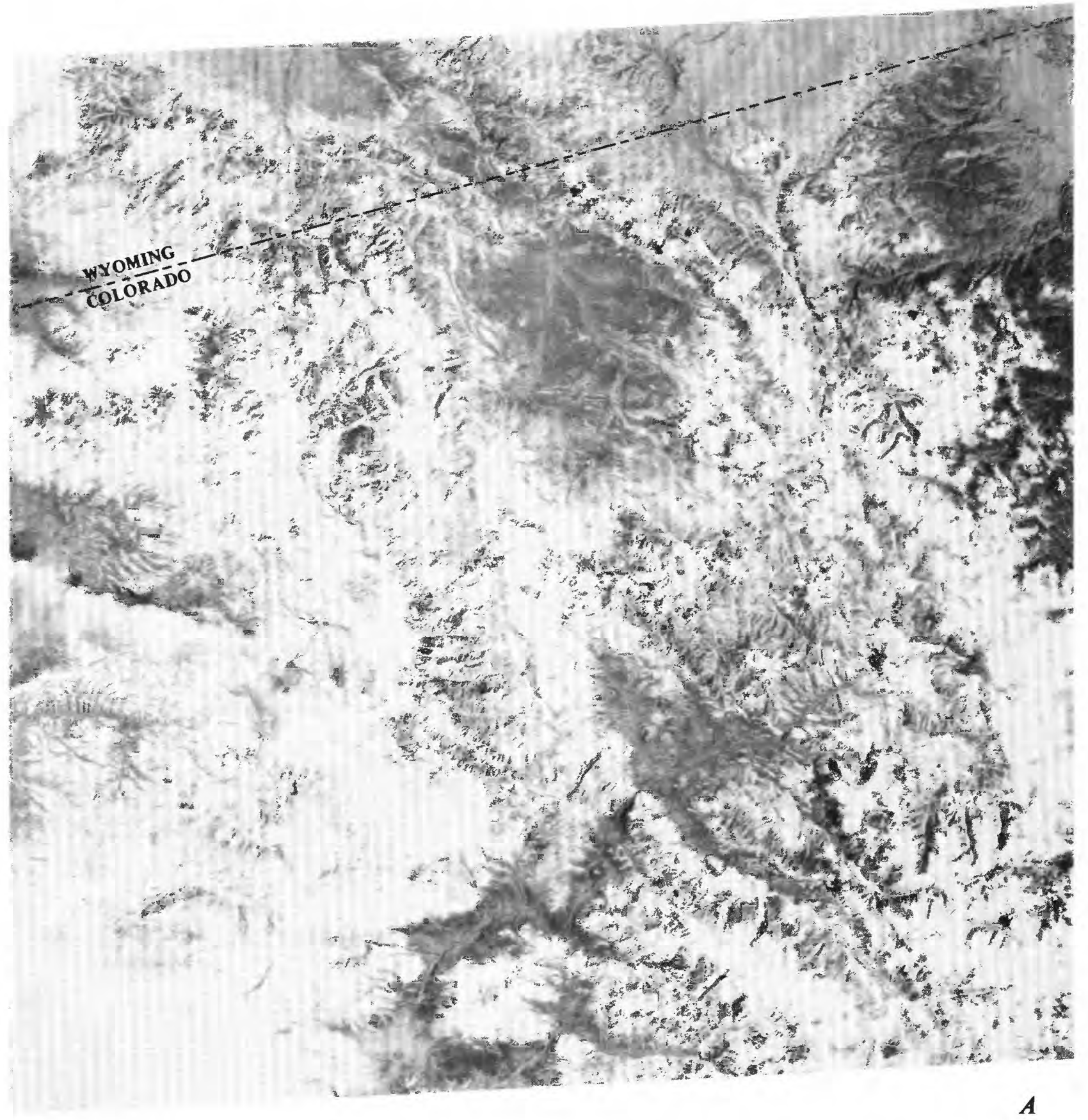

Figure 17. Snow cover in

ber 1977, they were below normal for 15 months of the 17 months through March 1978 . At Steamboat Springs, flows were below normal for 17 of the 18 months from October 1976 through March 1978, the exception being February 1978.

The flow of the Colorado River near Cisco, Utah, near the Colorado-Utah State line, when adjusted for changes in upstream storage, set record low monthly means for March through July 1977. Records began in 1911. Record low unadjusted daily discharges for the month occurred in March, April, and June.

The average flows of several streams in Colorado during May 1977 were well below the previous record lows for May which were set in 




Colorado Rockies.

1931 or 1934. The 1977 flow of the Animas River at Durango was 51 percent of the previous low and that of the Yampa River at Steamboat Springs was 99 percent. Monthly flows were in the lowest quartile during June and July 1977 at Steamboat Springs and during May and June at Durango. The annual runoff at Steamboat Springs was 97 percent and that at Durango was 88 percent of the previous minimum annual runoff which occurred in 1934.

The average flow of the White River near Meeker in northwestern Colorado during the first 13 days of July 1977 was $70 \mathrm{ft} 3 / \mathrm{s}$ which is 63 percent of the previous minimum daily flow that occurred on July 17, 1934. The San Juan 
River near Bluff, Utah, 50 mi west of the Four Corners, would have been dry in July 1977 if releases from Navajo Reservoir had not been made.

Numerous thunderstorms during the latter part of July in Colorado increased the flows significantly, some enough to reach the normal range for a few days during the last week in July.

The annual runoff for the 1977 water year at four index gaging stations in Colorado was the lowest of record for periods ranging from 31 to 69 years. Frequency relations of annual flows for these four sites indicate that the drought in 1977 was the most severe since the area was settled.

Though the annual runoff of the Yampa River at Streamboat Springs, Colo., for the water year 1977 was only 4 percent less than that in 1934, the timing of the runoff was different. The October to March runoff in 1977 was 66 percent of that in 1934, a difference of 13,550 acre- $\mathrm{ft}$, because the carry-over effect from 1933, an above normal year sustained the flow in 1934; whereas, the flow in 1977 was less because 1976 was a below normal year. The opposite occurred during the months April to September when runoff in 1977 was 8,920 acre-ft more than during the same months in 1934.

Storage was reduced to record low amounts in many reservoirs. By the end of June 1977 storage was down to 25 percent of capacity in a reservoir from which Cortez, in southwestern Colorado, obtains its water supply. Another reservoir in the area had only 15 percent of capacity and a third was dry-all at a time of year when they are normally nearly full. At the same time, the primary water supply for Price, Utah was exhausted, and the city had to depend upon Schofield Reservoir which was only half full. By September 30, 1977, storage in Flaming Gorge Reservoir on the Green River at the Wyoming-Utah State line was only 76 percent of average. The decrease in storage since September 30, 1975 in Flaming Gorge Reservoir and in Lake Powell on the Colorado River at the Utah-Arizona State line was 5.63 million acre-ft, and 86 percent of this occurred in 1977 .

The storage reservoirs for the Colorado-Big Thompson Project are near the headwaters of the Colorado River. Runoff into them in 1977 was only 124,000 acre-ft or 52 percent of average, but the transmountain diversions to the South Platte River basin on the eastern side of the Rocky Mountains amounted to 309,000 acre-ft or about 140 percent of the average annual diversion. Contents of Shadow Mountain Lake were held within a narrow range during the 1976 and 1977 water years, but storage in Lake Granby was reduced 269,100 acre-ft in the 2-year period.

\section{Ground-water Conditions}

The direct effect of the drought on groundwater levels with respect to reduced recharge was masked by the effects from increased pumping.

There are only five areas in the Upper Colorado Region in Utah where ground-water use is significant, and major development has occurred only in the one near Loa in southcentral Utah. The average withdrawal of ground water is 23,000 acre-ft and during the drought years this was increased to 35,000 acre-ft in 1976 and 37,000 acre-ft in 1977. During 1977, about 300 wells were drilled, and of these 50 were large withdrawal wells. The maximum decline in water levels from limited data in Utah was $8.6 \mathrm{ft}$ near Loa.

In Colorado, changes in ground-water levels in 1976 and 1977 were within the range experienced in other years. The discharges of springs were noticeably low, but the overall effect of the drought on ground water was minimal.

\section{Water Quality}

Minor changes in dissolved-solids concentrations were observed in many streams, but these were similar to the changes that occur in nondrought periods. The reduced flows in some streams were not sufficient to flush and dilute contaminants or the return flows from irrigation.

The lower peak flows and annual runoff were accompanied by reduced sediment discharge on many streams.

\section{Activities Resulting from the Drought}

A large proportion of the water supply for the Denver metropolitan area comes from the upper Colorado River basin via transmountain, inter-basin transfers. Because of the drought 
situation in the mountains in March 1977, the Denver Water Board requested residents to voluntarily stop watering lawns. Later, the deteriorating water supply forced the Denver Water Board to abandon their program for voluntary reductions of water use and to restrict lawn watering to 3 hours every third day. In Grand Junction, Colo., and Price, Utah lawn watering was restricted to 2 days per week, and in Cortez, Colo., lawns could be watered only 3 days per month. In July 1977 the city of Rangely north of Grand Junction had to discontinue supplying water to an oil company.

A flow of $76 \mathrm{ft} 3 / \mathrm{s}$ for irrigation was released in March 1977 from Taylor Park Reservoir in the Gunnison River basin east of Grand Junction, Colo.,-a very unusual occurrence for that time of year.

Monticello, near the southeast corner of Utah, imposed a strict water use limit of $\mathbf{5 0}$ gal per person per day for about 2 months. When rationing ended on July 1,1977 , after four new shallow wells were put into production, the rates were increased so that residential usage over 15,000 gal per month would be very expensive. Also, plans were made to drill a deep well to provide a firmer supply in the future.

Vernal, Utah set up a water rationing program on April 1, 1977 on an honor system. Outside water use was to be limited to twice a week between the hours of 6 and 12 p.m. A brochure, "The Water Hole is Drying Up," was prepared to educate the public on the need for and how to practice conservation; and it was used by the media and the schools.

The Governors of Colorado and Utah appointed special committees to coordinate activities related to the drought. In Utah, the committee approved $\$ 500,000$ of special funds mainly to drill and equip wells for domestic supplies at 19 locations in eight counties. The committee also approved loans totaling $\$ 204,000$ to provide emergency water for livestock from new wells and pipelines.

Disaster designation was approved for 41 counties in Colorado, New Mexico, Utah, and Wyoming.

\section{The Great Basin-WRC Region 16}

The Great Basin (fig. 18) includes most of Nevada, western Utah, and parts of California, Idaho, Oregon and Wyoming. The drainage consists of numerous closed basins with the headwaters of many streams in mountains where snow is the predominant form of precipitation. The streams traverse valleys down to lakes, sinks, or playas where there are no natural surface outlets.

A summary of the 1976-77 drought is presented in the next few paragraphs.

Below normal precipitation, particularly as snow in the mountains, produced a severe drought. Frequency analyses show that on the basis of streamflow, the drought had an average recurrence interval greater than 100 years. The low runoff had to be augmented by substantial reductions of storage in reservoirs, and the level of Lake Tahoe was below the level of its outlet for 3 months.

Ground-water levels in many basins did not change much, but locally declines ranged up to $24 \mathrm{ft}$. Water quality of both ground and surface water was not seriously affected.

Water use was restricted in some communities, many new wells were drilled, and emergency actions had to be taken to provide water for towns and for livestock.

\section{Previous Droughts}

Drought in the Great Basin is nothing new. In 1934 when snow surveying was a relatively new technique for forecasting runoff from the snowpack, the water content of the snow cover on March 29 in the Weber River basin north of Salt Lake City, Utah was only 27 percent of that in 1933. The winter was warmer than average; therefore, some water users started irrigating as early as the latter part of March and most of them were irrigating by April 15 . Releases of water in storage started on April 18 about 2 to 2.5 months earlier than usual. There was not enough water to meet everyones' needs, but most of those holding older water rights temporarily gave up part of their water to those with junior rights so that all would be able to start irrigating. The snowmelt runoff was short-lived and peaked early, about May 8.

To augment the water supply, Federal funds were used to pay for the lowering of the outlets of four lakes. About 200 acre-ft was obtained in this manner. Between late June and early August 1934 several canal companies turned off their diversions so that water could be used by other canal companies to save hay 


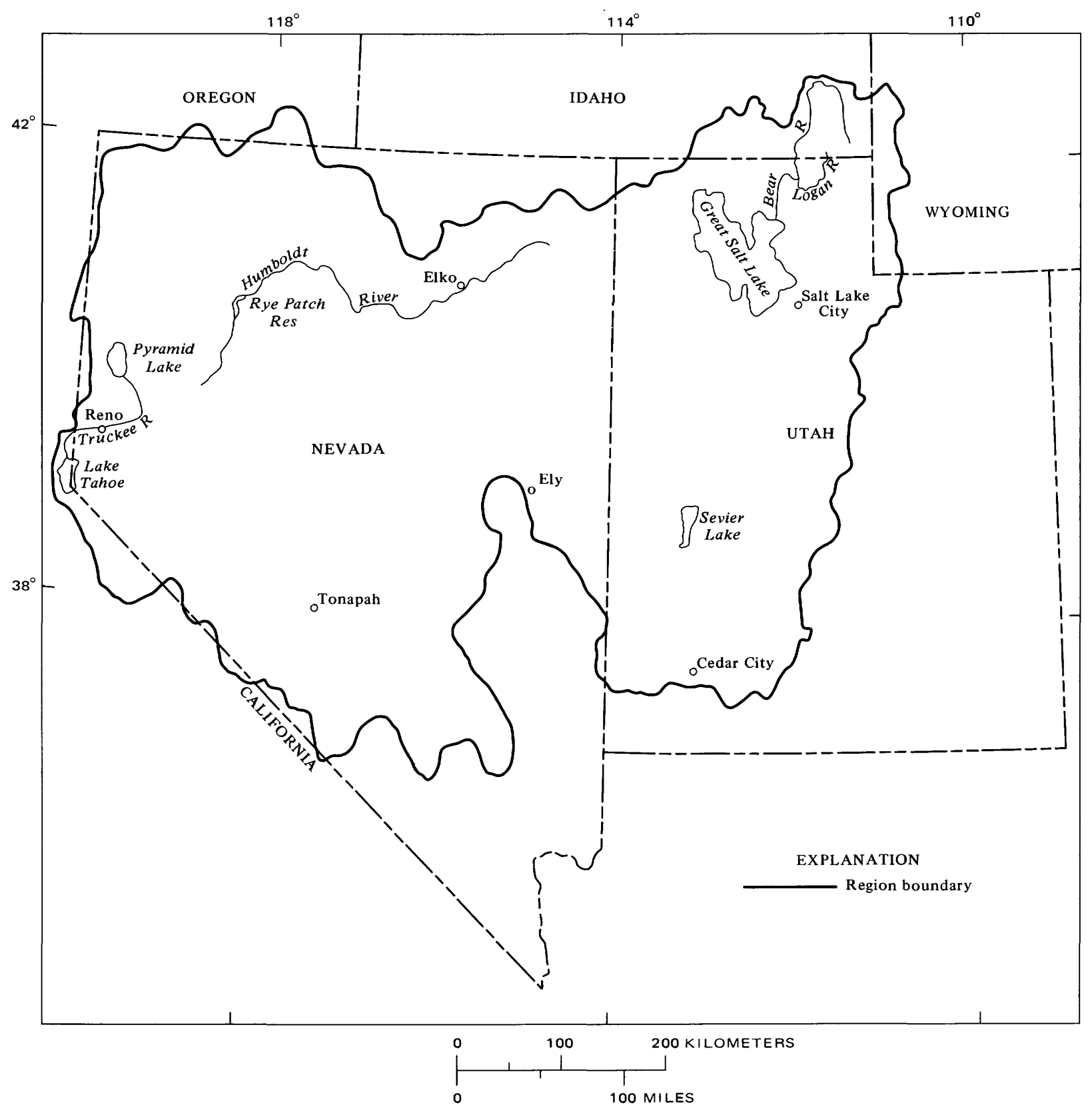

Figure 18. The Great Basin-WRC Region 16.

and grain. By September 1934 the Weber River near Oakley, Utah was flowing at 28 $\mathrm{ft} 3 / \mathrm{s}$, a new minimum in a record which started in 1904.

The next most severe drought in Utah occurred in 1961. The effects of the 1961 drought were felt more in some areas than in 1934 because more acreage was being irrigated. Widespread irrigation started early in the spring, distribution of water was made under low-water agreements after June 9, a time of year when high flows are prevalent, and those with rights subsequent to 1936 received no water unless they could purchase it. Sewage effluent from the treatment plant at Ogden was used in one district.

Storage in reservoirs was reduced drastically, and some reservoirs held less than in 1934. Many wells went dry in August. Nesting areas in the Ogden Bay Bird Refuge dried up 
during the summer, and the waterfowl population was reduced.

The Great Salt Lake is a good barometer of overall wet and dry conditions. During the wet period from 1861 to 1873 the lake rose $10.8 \mathrm{ft}$ to a high level of $4,210.5 \mathrm{ft}$. Since then the lake has fallen to low levels in 1905, 1940 and 1963 with intervening high levels in 1923 and 1952. The development of irrigation and other consumptive uses in the Great Salt Lake basin is one of the reasons causing the general decline from the 1870 's to the low of $4,191.4 \mathrm{ft}$ in 1963.

However, no major changes in irrigation use have occurred in about 15 years; therefore, the rise and fall of the Great Salt Lake is in direct response to wet and dry conditions. From 1963 to 1976 the trend was wet, and the lake rose $9 \mathrm{ft}$ to $4,200.4 \mathrm{ft}$ in 1976 -a level 0.8 $\mathrm{ft}$ higher than that in 1952. But in the 1977 water year the lake dropped $1.5 \mathrm{ft}$ which is comparable to the $2.0 \mathrm{ft}$ drop during the drought of 1933-34 and the $1.7 \mathrm{ft}$ drop in 1961 . The latter two values were at elevations 2.0 to $7.0 \mathrm{ft}$ lower than in 1977; therefore, the volume of water lost was less. The water level continued to fall another $0.3 \mathrm{ft}$ until December 1,1977 when one of the latest seasonal minimums occurred. The recession from the high level in 1976 to the lower level of December 1,1977 represents an evaporation loss of about 3.41 million acre- $\mathrm{ft}$ which is a reduction of 20 percent in volume.

\section{Precipitation and Runof $f$}

Precipitation during 1975 in the Great Basin was generally near normal-within a range between about 10 percent below to 20 percent above normal. Deficiencies developed in 1976 as precipitation dropped to the 70 to 85 percent of normal range in many places. Though precipitation recorded at some valley floor locations was near normal, the snowpack in the mountains was below normal. See figure 24 for conditions in the Sierra Nevada which is the western boundary of the Great Basin.

Many valley floor locations had near normal precipitation again in 1977 , though the heavy rains in May, at Salt Lake City, Utah and Ely, Nev., for example, accounted for about 30 percent of the total. At Alton in southern Utah, the total precipitation for the season from October through April was only
2.20 in. which is 20 percent of average and less than half the previous minimum. The snowpacks in the Sierras and in the Wasatch Range were much below normal, and their record low water content was the major cause of the drought. By May 1, 1977 most of the snow had melted. Another associated factor was the unseasonably warm temperatures in April. Large amounts of precipitation, 5 to 10 in., between May 1 and June 15, 1977 at high elevations in Nevada improved the seasonal runoff over that forecast for the Humboldt River.

Runoff in the 1975 water year was above normal on the Truckee and Humboldt Rivers in Nevada and the Logan River in Utah. At Palisade on the Humboldt River about $25 \mathrm{mi}$ southwest of Elko, Nev., 1975 was the seventh consecutive year of above normal runoff, but on the Truckee River east of Reno only five of those seven years were above normal, and just four of those seven years were above normal on the Logan River north of Salt Lake City. Overall, streamflow prior to the 1976-77 drought reflected good water supplies.

During the 1976 water year, the runoff picture was mixed. The adjusted flow of the Truckee River dropped to 24 percent of normal though the actual flow was 77 percent of average. This was accomplished by depleting the water in storage in Lake Tahoe and five reservoirs in the Truckee River basin by 365,000 acre- $\mathrm{ft}$. This is the second largest reduction in storage since 1900 when records began and is only 5,000 acre-ft less than that in 1924. At Palisade, Nev. the Humboldt River runoff decreased to 76 percent of normal, but the Logan River runoff was 96 percent of normal.

The runoff during the 1977 water year indicates the effect of the continuing drought and its spread. Once again, a large release, 355,000 acre-ft, of stored water in the Truckee River basin, maintained flow in the Truckee River. The actual flow at the mouth was only 14 percent of average. Without the releases from storage, the Truckee River would have had very little flow at its mouth, probably just some return flow from local irrigation.

The Carson and Walker Rivers, draining the eastern slopes of the Sierras south of the Truckee River, had record low annual flows in 1977, about 23 percent of average. The 
average flow of the Humboldt River at Palisade in 1977 dropped to $130 \mathrm{ft} 3 / \mathrm{s}$ or 35 percent of normal. However, the average annual flow has been less in nine other years. The minimum annual flow was $34.8 \mathrm{ft} 3 / \mathrm{s}$ in 1934 , and three consecutive years, 1959-61, were less than 1977 and averaged $100 \mathrm{ft} 3 / \mathrm{s}$.

A new record low annual runoff occurred on the Logan River above State Dam, near Logan, Utah during the 1977 water year. The very low snowpack in the Wasatch Range was the primary cause. Though a new low in 81 years of record, the runoff was less than 10 percent below the runoff in 1931, 1934, 1941, and 1961.

A low-flow frequency analysis for the Beaver River near Beaver, Utah which is about $48 \mathrm{mi}$ northeast of Cedar City shows that flows in 1977 for all periods from 1 to 365 days were new minimums of record in 63 years of record. The flows have probabilities ranging from 0.01 to 0.0033 which are equivalent to recurrence intervals of 100 to 300 years. In 1976, low flows of the Beaver River were in the 5- to 13-year recurrence-interval bracket.

The large reduction of storage in the Truckee River basin is mentioned above; however, there is other information of interest. The bulk of the releases from storage came from Lake Tahoe which dropped below the level of the lip at its outlet on September 22, 1977 and remained below until December 27, 1977. This was the first time that this has happened since 1962. Plans were made to pump water from Lake Tahoe into the Truckee River, but the legal implications and the cost could not be resolved; therefore the Truckee River flow below Lake Tahoe was only local inflow.

The Truckee River flows into Pyramid Lake northeast of Reno, Nev., and the drought reduced the inflow to the lake so that the water level of Pyramid Lake dropped $0.8 \mathrm{ft}$ in 1976 and $2.9 \mathrm{ft}$ more in 1977. The 2-year decrease in storage was 400,000 acre-ft, but this was less than half the 960,000 acre-ft decrease that occurred in 1930-31.

Storage in Rye Patch Reservoir on the Humboldt River decreased 92,250 acre-ft during the 2-year drought. This is equivalent to the average inflow from the Humboldt River for about 8 months. Usable storage in Topaz Lake in the Walker River basin, Nevada was depleted to zero by August 1977, a reduction of 22,500 acre-ft. Thereafter, only the current runoff was available for irrigation.

Reservoir storage in Utah was near 50 percent of average by October 1977 even though Bear Lake and Utah Lake, the two largest reservoirs, were at 76 percent of average. All usable storage was released from several small reservoirs.

\section{Ground-water Conditions}

The aquifers in many parts of the Great Basin are large with respect to the demand for ground water; therefore, with only a few exceptions, increased pumping from existing wells and the added withdrawals from new wells had no major or long-lasting effect on ground-water levels. There were recharge areas around the margins of some closed valleys where moderate declines of a few feet occurred, but there was little or no change in water levels in the central parts of the valleys.

Where ground-water development exists in closed basins, the declining trend in water levels caused by pumping greatly exceeds the changes that can be attributed to the drought. Ground water is the sole source of water other than small amounts of precipitation in many areas; therefore, the amount of water pumped during a drought is not much more than that pumped in a normal year. In Diamond Valley south of Elko, Nev., the water-level declines in 1977 were close to the rate of decline in previous years.

Ground-water levels in valleys along the principal rivers in Nevada were directly affected by the drought. There was less recharge from the streams and from deep percolation of irrigation water, and water levels were lowered by heavier pumping of ground water to supplement deficient surface supplies. For example: Reno and Sparks, Nev., normally obtain about 30,000 acre-ft per year from the Truckee River and pump 6,000 to 7,000 acre-ft per year of ground water for municipal uses. During 1976, releases from storage provided sufficient flow; but in 1977, streamflow was not sufficient, and nearly 20,000 acre-ft was pumped to offset the deficiency. However, the water level decline was not excessive anywhere in Truckee Meadows.

In the Smith and Mason Valleys along the Walker River, ground-water pumpage in 1977 
was about three times normal. The annual net water-level decline was several feet, but a wet year or two will probably replenish the groundwater reservoir. Similar responses to the drought also occurred along parts of the Humboldt and Carson Rivers.

The average number of new welis drilled each year in Nevada is about 600. During 1977 , about 1,200 wells were drilled, most of them because of the drought.

In Utah, the drought brought on a flurry of well drilling. About 1,100 new wells were drilled in 1977 and 180 of them were capable of large withdrawals. The number of new wells in the Great Basin was more than twice the average number of wells drilled per year statewide. The average annual withdrawal from wells is 570,000 acre-ft. In 1976 the pumpage rose to about 660,000 acre-ft, and in 1977 it increased to about 740,000 acre-ft, 30 percent above average. Close to 70 percent of the water pumped was used for irrigation, half the remainder was used for public supplies, and the other half was split between industrial use and domestic and stock use.

Declines in ground-water levels in 1976 and 1977 were general, and maximum declines ranged up to $24 \mathrm{ft}$ in localized areas. In other localized areas, water levels rose as much as 6 $\mathrm{ft}$. The irregular pattern is indicated by the changes in water levels in the Pavant Valley, about half way between Salt Lake City and Cedar City, where the $24 \mathrm{ft}$ decline was observed, yet only $12 \mathrm{mi}$ away a rise of $3.1 \mathrm{ft}$ occurred. See figure 19. The month end water levels in 11 selected observation wells were new record lows for one or more months in 1976 or 1977 . Some of the 1976 records lasted only to 1977 when new lows were reached. The low-level trend extended through March 1978 in four of the wells.

Because the drought reduced the flow in the streams that provided most of the water to the Salt Lake County Conservancy District, the amount of water pumped from the District's wells in 1977 was double the usual amount. On the other hand, the conservation program at Sandy, Utah about 8 miles south of Salt Lake City was so successful that water use from wells was reduced 19 percent.

In southeastern Idaho, aquifers in the Bear River area had declines ranging from 1 to $11 \mathrm{ft}$ that were caused by severely reduced recharge and increased withdrawals.
Water Quality

Water quality of streams, lakes, and aquifers was virtually unaffected by the drought. The majority of the streams in the Great Basin are ephemeral; therefore, when a drought occurs, some streams may not flow at all and others will go dry earlier than usual. Though the timing of the runoff pattern is changed, the pattern is similar to normal conditions; and any change in water quality is not necessarily related to the drought.

Lakes and reservoirs are low in the fall in normal years because the water is released to meet the demands for irrigation, the fishery, compacts, etc. Reservoir levels were lower than usual in the fall of 1977 , but no serious water quality problems developed.

The additional stresses on the aquifers were small over the 1- or 2-year duration of the drought, and water quality did not deteriorate significantly. Some of the water pumped for irrigation in Pavant Valley, Utah returns to the aquifers as recharge and is withdrawn again for irrigation. This recirculation does affect the chemical quality of the water. At the five sites shown in figure 19 where water quality is monitored, the general trend since 1957 has been an increase in the concentration of dissolved solids. The trend was not changed by the drought in four of the wells; but in the well in section 8 of township 23S, range $6 \mathrm{~W}$, the trend was reversed, the concentration decreased more between 1976 and 1977 than in any other year. A longer drought period might have brought some changes in a few areas.

\section{Forests}

The effect of the drought on forests in the Great Basin was not significant with respect to the number of fires or the acreage burned. The heavy precipitation in May and June in the forested areas and summer thunder storms apparently provided enough moisture to the tinder to inhibit the start of an abnormal number of fires.

The trees in an area south of Reno, Nev., and on the east slope of the Sierras near Washoe Lake had a high rate of die off. An inspection showed that the continued drought in this area was the prime cause and not insects or disease. 


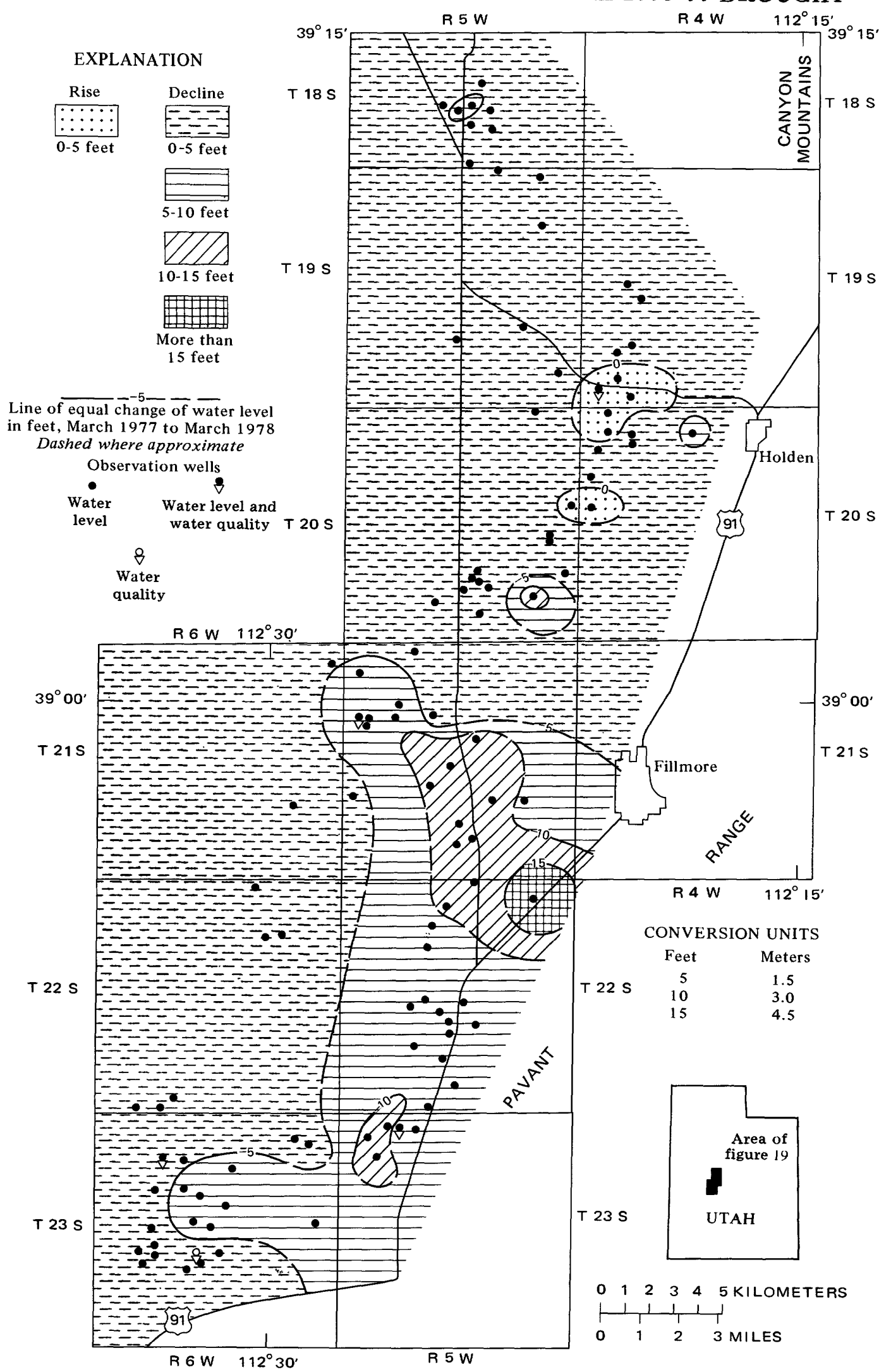

Figure 19. Map of Pavant Valley, Utah, showing change of water levels from March 1977 to March 1978. 


\section{Activities Resulting from the Drought}

Water restrictions were imposed by a number of cities or water distribution companies. In Utah, most of the restrictions were in effect only for 2 or 3 months starting in May 1977. Residential water use for lawn watering, car washing, and so forth was banned during most of the daylight hours and was allowed only every other day. Most of the quotas per residence ranged from 17,000 gal to 33,000 gal per month. These were quite liberal, but the fines for exceeding the quota were steep, $\$ 10$ per 1,000 gal. In Provo, south of Salt Lake City, Utah, violators were guilty of a misdemeanor and subject to a maximum fine of $\$ 299$ and 30 days in jail. Customers in Salt Lake County who did not pay fines faced disconnection and a $\$ 50$ charge to reconnect. Water rates were raised in some areas. The conservation measures were effective, and residential water use was reduced 20 to 35 percent. Rations for businesses were usually set at 75 percent of the use in 1976 , and at 50 percent for irrigation.

The Governor of Utah appointed a State Drought Relief Committee that approved $\$ 300,000$ of special funds mainly to drill and equip wells at 14 locations in nine counties. The committee also approved loans totaling $\$ 240,000$ to provide emergency water for livestock. The loans were for wells, pumps, and pipelines. Irrigation water use was reduced because some farmers kept part of their land out of production.

Recreational activities were restricted at some reservoirs because of low water levels, but most of the problems were mainly a matter of some inconvenience or a nuisance.

Disaster designation was approved for 33 counties in the region.

\section{Pacific Northwest-WRC Region 17}

The Pacific Northwest Region (fig. 20) is that part of the Columbia River basin in the United States plus the coastal streams of Oregon and Washington, and the closed basins in southeastern Oregon. The water supply of the entire region is highly dependent upon the precipitation, mainly as snow, in the mountain ranges from the Olympics of Washington and the Cascades of Oregon and Washington to the
Rocky Mountains of Idaho, Montana, and Wyoming. Therefore, a subnormal snowpack, such as that which occurred in the winter of 197677 , introduces a severe stress on all activities requiring water.

A brief description of the 1976-77 drought follows:

The drought in the Pacific Northwest did not develop until the winter of 1976-77 when precipitation was well below normal. The record low water content of the snowpack was the main factor that caused the runoff in 1977 of the Columbia River at The Dalles, Ore., adjusted for storage, to be the lowest since 1879. Annual flows were record low at other long-term gaging stations.

Most declines of ground-water levels were less than $10 \mathrm{ft}$, but as much as $25 \mathrm{ft}$ occurred in Idaho. Adverse water-quality effects were minimal and temporary. Higher water temperatures caused fish kills in Idaho and Washington.

A special effort was planned and carried out to help preserve the juvenile fish, electric power deliveries to selected users were reduced, and water rationing was necessary in only a few towns, though some water tanks were installed to help small communities over the water shortage.

\section{Previous Droughts}

Evidence indicates that a prolonged drought occurred in part of the region during some undetermined period in the past. Freeman (1929) found yellow pine stumps in Granite Lake, Williams Lake, and several other lakes southwest of Spokane, Wash., when the lake levels receded in 1926 to the lowest levels known in at least 60 years. The stumps had over 100 tree rings, and yellow pine needs a well-drained soil in which to grow. Therefore, Freeman concluded that at least the Columbia Plateau was affected by a drought period lasting more than a century.

Also, Goose, Malheur, and Harney Lakes in southeastern Oregon were at very low levels in 1926, and well-defined wagon ruts were found in the dried bed of Goose Lake. Presumably the ruts were made by pioneer wagons in the 1840 's as they followed the Applegate Trail which crossed the dry lake bed south of the small lake that existed at that time. This information implies that drought conditions 


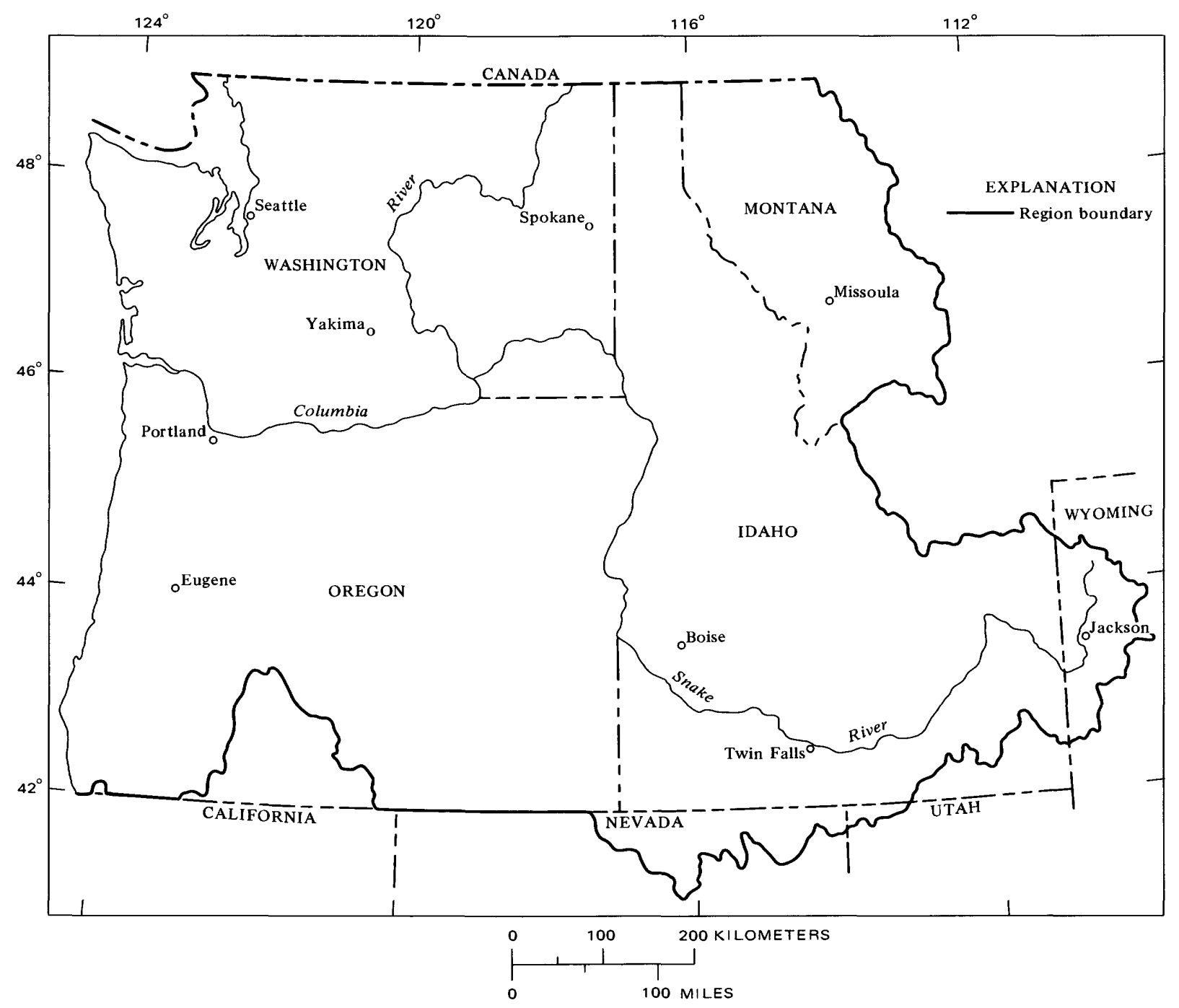

Figure 20. Pacific Northwest-WRC Region 17.

existed in the vicinity of Goose Lake for a number of years. Lake levels have been high enough since the late 1850 's to submerge the ruts.

\section{Precipitation and Runoff}

From 1972 to 1975, precipitation and runoff had been normal to much above normal except in 1973. Runoff for the 1973 water year was among the lowest 25 percent of record, but that year was between two years of runoff well above normal. Precipitation during the 1975-76 season was near normal or above normal, and runoff was above the median value, near 125 percent of normal. Reservoir storage was about average on
October 1, 1976. Therefore, the Pacific Northwest Region was not experiencing a drought in 1976.

But 1977 was quite another story. Winter precipitation in western Montana was about 50 percent of normal, ranged from 10 to 40 percent in Idaho, and from 40 to 60 percent of normal in most of Oregon and Washington. Because temperatures were above normal during the late fall of 1976 and the winter months, precipitation, which was below normal, occurred as rain and contributed to the runoff rather than occurring as snow and augmenting the snowpack. One example: The storm of January 16-18, 1977 was warm enough to produce rain at high elevations and actually reduced the below normal snowpack in the 
southern ranges. In Washington during the January storm, the water content of the snowpack remained about constant, which meant that the subnormal snowpack was farther below normal after the storm than it was before. The ensuing precipitaiton was not sufficient to replenish the snowpack up to normal; therefore, the spring and summer runoff from snowmelt was deficient.

The abnormally low winter precipitation caused poor soil moisture conditions though normal or greater precipitation in March in western Washington, in May in Idaho, Oregon and Washington, and in August and September in most of the region improved conditions. See figure 7 for an index of the drought severity.

The water content of the snowpack in the Columbia River basin was less than the previous record low amounts from January to May 1977 (fig. 21) and ranged from 30 percent of normal on January 1 to 50 percent of normal on April 1. Bare snow courses were prevalent by May 1. Snowmelt started earlier than usual-in the latter part of April in the Flathead River basin. This abnormal timing brought storage in many Montana reservoirs above 100 percent of average for May $1-a$ deceptive statistic because the remaining snowpack had very little water left to contribute to the seasonal runoff that usually occurs in May and June. The maximum discharge for the year occurred in May on many streams; and later, some smaller streams went dry for the first time since observations have been recorded.

The difference in the areal extent of the snowpack in part of the Columbia River basin between 1976 and 1977 is depicted in figure 22. The snowcover in April 1976 is shown in figure 22a, and that in April 1977 is shown in figure $22 \mathrm{~b}$. The photographs were obtained from Landsat satellite imagery and cover an area approximately $115 \mathrm{mi}$ on a side. Lake Washington at Seattle and part of Puget Sound near Tacoma are near the left edge, Mt. Rainier is near the bottom edge, Lake Chelan is the dark eel-like image in the upper right, and the Columbia River is the dark line from the upper right corner down to the lower right edge past Wenatchee in the right center. Some cloud cover obscures the ground in parts of figure $22 \mathrm{a}$.

Streamflow in western Montana dropped into the below normal range (less than 75 per-

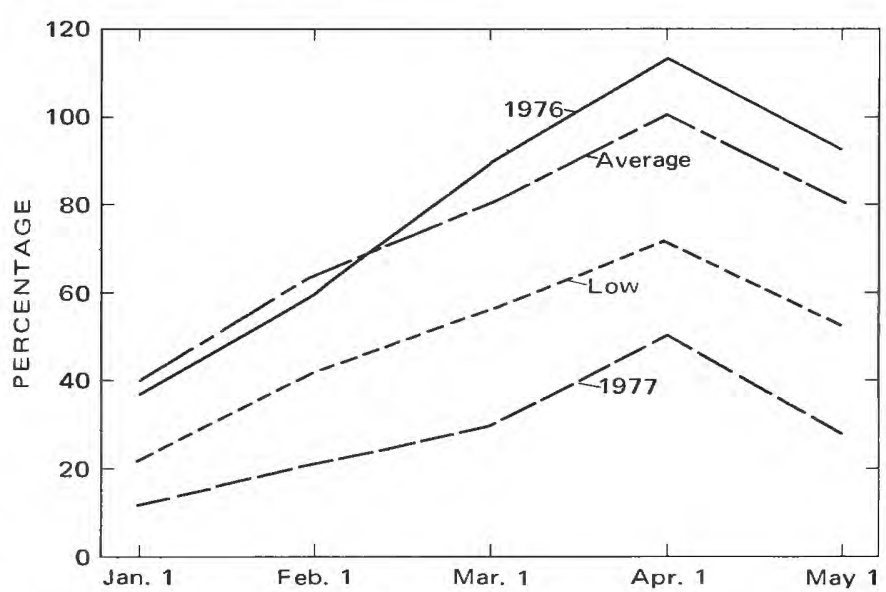

Figure 21. Water content of Columbia River basin snowpack as a percentage of the April 1 average.

cent of normal) by March 20, 1977. Normal, though declining, runoff occurred in May in those basins that included some high elevations where remnants of the snowpack still existed; otherwise, flow was below normal. Many streams were nearing record low flows for the month of June. The Middle Fork Flathead River near West Glacier had not been so low since 1941, and the Clark Fork at St. Regis was lower only in 1926 and 1931. The low runoff continued for the remainder of the water year, and the annual runoff near West Glacier was the third lowest in 38 years of record and that at St. Regis was the second lowest since records began in 1911.

During the spring of 1977 streamflow in Idaho fluctuated between normal and deficient, depending upon the range of elevation in a basin, the water content of the small snowpack, and the precipitation during the spring. Many irrigators received only 60 to 80 percent of their usual supply, but with prudent use of the supply and fortuitous timing of some rain during the growing season, irrigated crops fared very well. The usual irrigation season was shortened about 30 days so that water could be stored for future use.

By May 1, 1977, flow in the Snake River at Weiser was the lowest it had been since 1924, and the mean flow for June was the lowest monthly mean in 67 years of record. Drought conditions continued through September 30, the end of the water year; therefore, the mean annual runoff was the minimum of record at 


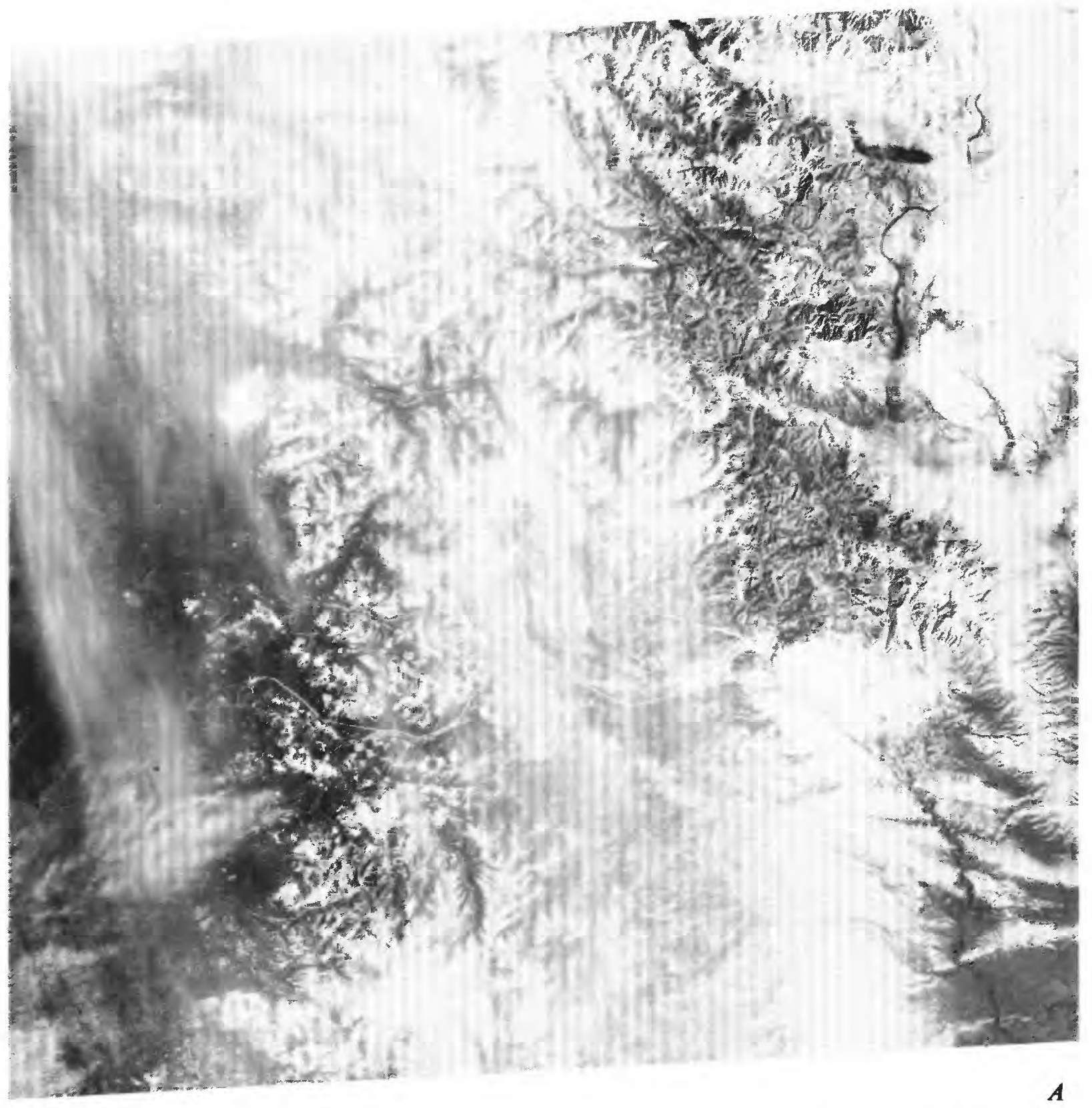

Figure 22. Snow cover in

many gaging stations including the Boise River near Boise with 83 years of record, the Coeur d'Alene River at Enaville, the Clearwater River at Orofino, the Weiser River near Weiser and the upper Snake River near Heise with records between 58 and 67 years long.

Spokane Falls, near the center of Spokane, Wash., went dry in mid-August 1977. The
Washington Water Power Co. received a waiver from the Federal Energy Regulatory Commission so that it did not have to maintain flow over the falls for the duration of the drought.

The discharge during the 1977 water year of the Columbia River at The Dalles, Ore., 


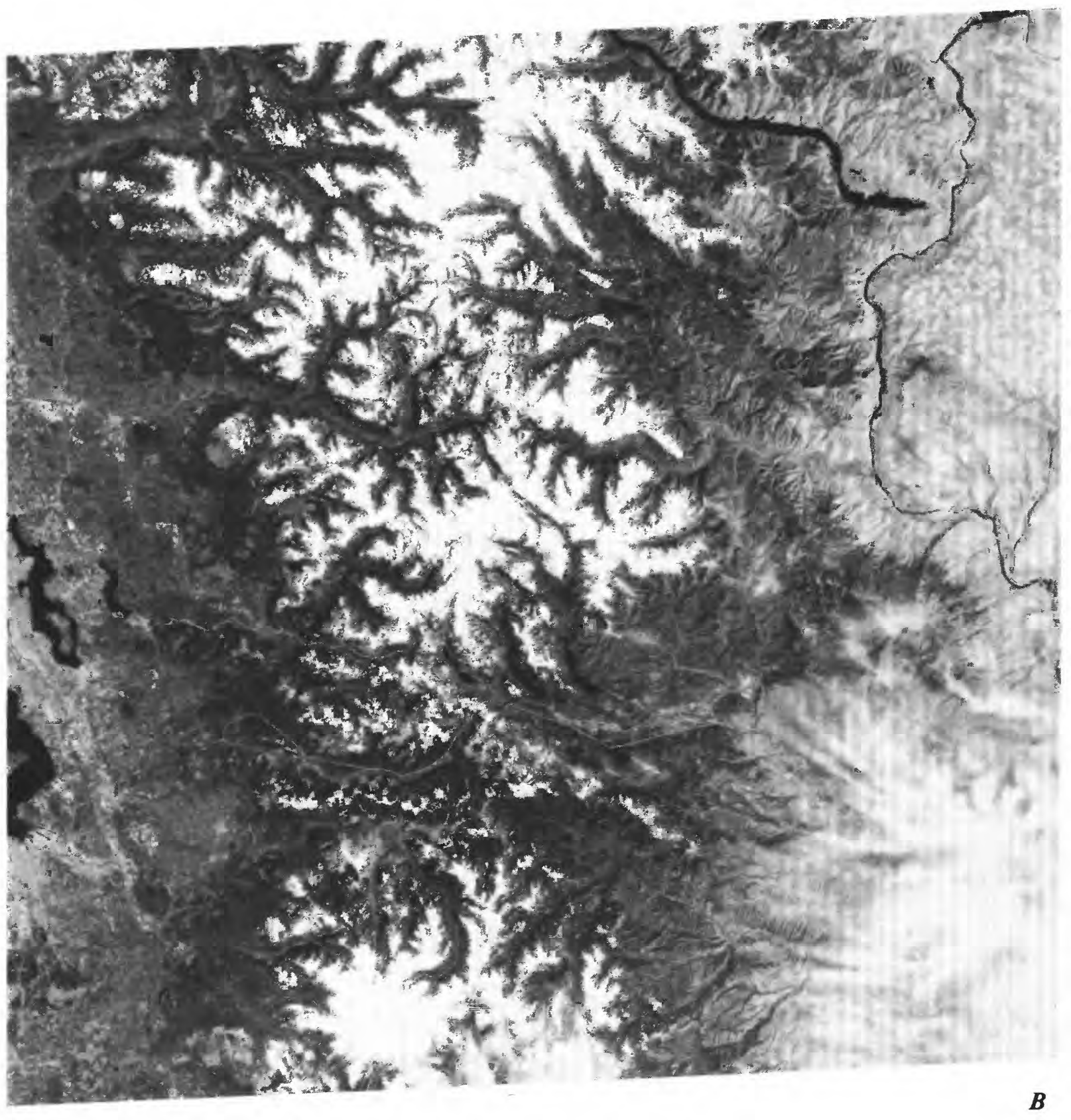

the Cascades, Wash.

adjusted for controlled storage, was the lowest of record in 99 years.

An interesting statistic that emphasizes drought conditions is the fact that most of the runoff in the Yakima River basin in Washington for the 6 months ending in mid-March 1977 was stored in reservoirs and amounted to 295,000 acre-ft. This is about the same amount as that stored in 3 days during a flood in December 1975.

Streamflow in 1977 was the lowest recorded for most of the streams in Oregon, particularly those in western Oregon. One of the significant aspects of the runoff pattern is the extremely low magnitude of the annual peak discharges in western Oregon. For exam- 
ple: There are 61 years of record for the Umpqua River near Elkton where the lowest annual peak discharge prior to 1977 was 33,100 $\mathrm{ft}^{3} / \mathrm{s}$, recorded in 1915 . But in 1977 the peak discharge was just $13,000 \mathrm{ft} 3 / \mathrm{s}$ or 39 percent of that in 1915. On the other hand, record low minimum or daily flows were the exception rather than the rule throughout Oregon. Another anomaly related to the drought was the timing of the annual peak discharge. On the Applegate River near Copper in southwestern Oregon, the maximum discharge, 860 $\mathrm{ft} 3 / \mathrm{s}$, during the 1977 water year occurred on September 28,1977 only 16 days after the minimum discharge, $19 \mathrm{ft} 3 / \mathrm{s}$, occurred. Generally about 90 percent of the annual peak discharges occur between November 1 and March 31 near Copper and most of the others occur in October, April, or May.

Reservoir storage in October 1976 was about average, but the heavy drafts needed to supplement the low runoff in 1977 reduced the storage in a rather mixed pattern. In Idaho, reservoir levels were lower in 1977 than any time since the reservoirs were first filled. Some reservoirs supplying irrigation water in eastern Oregon went dry as early as August 1, though 25 of the major reservoirs used for irrigation in Oregon contained 773,000 acre-ft on October 1,1977 , which is 58 percent of the average for that date. In Washington, the rains in August and September prevented the irrigation reservoirs from being depleted as much as expected. In fact, they generally stored more water than they contained in 1973, the previous year with low runoff. Reservoirs used primarily for power generation were below normal.

\section{Ground-water Conditions}

Ground-water levels in western Montana were not affected by the drought except locally in shallow wells in the Bitterroot Valley south of Missoula.

Domestic wells in Idaho near Carey and in the Wood River basin went dry early in April 1977. See figure 4 for the effect of reduced recharge in a well east of Carey. Many shallow wells in six counties in western Idaho went dry in June.

Water levels in 400 wells in Idaho were monitored either on a bimonthly or semiannual schedule. Another 220 wells were measured in
March and September 1977 and again in the spring of 1978. Declines ranged from 0.2 to 25 $\mathrm{ft}$ between the fall of 1976 and the fall of 1977. The larger declines occurred in the valleys of tributaries to the Snake River from the south between the Raft River and Salmon Falls Creek in south-central Idaho. The declines are attributed to one or a combination of the following factors: Below normal precipitation caused reduced recharge, increased withdrawals of ground water to supplement diminished surface-water supplies, and more efficient use of irrigation water because supplies were restricted or irrigators tried to keep the additional costs to a minimum. Water levels in wells respond to irrigation practices whether the water applied is surface water or ground water.

The yield of wells in eastern Washington did not decline, but by early March 1977 water levels fell 3 to $10 \mathrm{ft}$ below the levels of the spring of 1976 to about the levels expected in the fall.

Water levels in two wells in the Kitsap Peninsula in western Washington were still declining on June 28, 1977, whereas in June 1976 they were approaching their seasonal high levels. Though ground-water levels were low, few of them reached record low levels. The few new record lows were not very significant because the short records do not include the drought of 1944. Near Tacoma, 3 of 29 wells in a water district went dry, but supplies were ample.

Ground-water supplies in Oregon were not generally deficient; however, the combination of less than normal recharge and greater than normal pumping produced abnormal waterlevel declines. In some areas record low levels were reached. In the dune area near Coos Bay, Ore., the additional pumping and low precipitation caused several sand-dune lakes to go dry. A drop in water level was not always bad news. The good news in some areas of the Willamette Valley in Oregon was that the lowered water table allowed good crops to be raised on fields that are too wet in normal years.

Water levels in parts of the Willamette and Tualatin Valleys of Oregon dropped to all-time lows or nearly so by February 1977 because the usual recovery from November through January did not take place. The water level in a well north of Eugene, Ore., was $9 \mathrm{ft}$ below 
average for February and only $0.8 \mathrm{ft}$ higher than the minimum of record which occurred in October 1966. Also, the water was at a record low level for each of eight consecutive months from November 1976 through June 1977.

\section{Water Quality}

A beneficial aspect of the drought was brought about by the additional water diverted from the Columbia River to Moses Lake and Potholes Reservoir, Wash., where algae growth was reduced. The additional water caused a significant drop in the nutrient concentration which is attributed to nutrients in the runoff from agricultural lands.

Water temperatures in streams rose because of the low flows. In a few streams the rise was sufficient to cause fish kills in Idaho and Washington.

Intensive monitoring of water quality was done by the Environmental Protection Agency to assess the impact of the drought at Lower Granite Reservoir, along the Lower Columbia River and the Yakima River, and at Grays Harbor. No emergency actions were needed to counteract the effects of the drought.

Salt-water intrusion into estuaries was not a problem in the Pacific Northwest. No serious deterioration of the quality of ground water was noted. The Blue Lakes Spring near Twin Falls, Idaho had dissolved-solids concentrations and nitrite plus nitrate concentrations in the normal range.

\section{Forests}

Forests and range lands in the Pacific Northwest were exceptionally dry in 1977. Lightning started fires in Idaho in April which is unusually early, and more than 100 fires occurred in both Idaho and Washington in April. During the entire fire season in 1977, there were 2,400 forest fires which burned 12,500 acres. In an average season there are 2,000 fires that burn 8,300 acres; therefore, the losses from fires were not as serious as expected considering the extra dry conditions. However, incidence of fires in Washington was about twice normal. The number of lightning caused fires in 1977 was the fourth highest since 1900 .
The drought did cause the loss of young, newly planted trees, and reduced the grazing in National Forests.

\section{The Fishery}

The low flows in 1977 that were near or below the minimum of record in many streams of the Columbia River basin, and the lower main stream discharges caused by the reduction in hydroelectric power generation placed an additional strain on the fishery resources. Therefore, an interagency Committee on Fishery Operations was formed to determine the amount of water needed to preserve the fishery and to resolve the conflicts between those competing for water for numerous important uses (Committee on Fishery Operation, 1977).

Three plans were developed and carried out: (1) Releases from Libby, Hungry Horse, and Dworshak Reservoirs were made to augment the low flows so that the juvenile fish would reach the ocean more rapidly; (2) Spills were made at nine main stem structures to help the young fish to pass the structures more easily and with fewer losses; (3) About 2.8 million juvenile salmonids were transported by barge and (or) truck from the lower Snake River to the Columbia River below Bonneville Dam.

The water actually used in May and June 1977 for the first two plans was 1.4 million acre-ft, most of which also was used to generate electricity. Surplus electrical energy was delivered to utilities in British Columbia, Oregon, and California to be returned by February 28, 1978. The return of the electrical energy was intended to reduce the demand for hydroelectric generation in the Columbia River basin and to allow storage of additional water to offset that used for the fishery. All the energy was returned and the net use of water was about 230,000 acre-ft and the net cost was about $\$ 2.2$ million. When the fish return in future years, the value of the increased fishery is estimated at $\$ 8.8$ to $\$ 10$ million. The truck-barge operation cost almost $\$ 1$ million, and the estimated value of the additional fish returning is $\$ 4$ to $\$ 6.5$ million.

The implementation of the three plans was accomplished at a lesser cost and with less 
impact on other resources in the basin than originally expected.

Pumping from the Walla Walla River in May 1977 reduced the flow enough to cause higher water temperatures and low dissolved oxygen which in turn caused a large fish kill. Also, warm water increases the incidence of disease in fish and a higher mortality rate in fish eggs which means the drought will have a long-term effect on fish.

\section{Activities Resulting from the Drought}

By February 1977 electric utilities requested the public to reduce the use of hot water and activities that required electrical energy so that water could be stored for future power generation. The response was disappointing; consequently, surcharges were imposed in May 1977. The combination of the public's voluntary reductions, above normal precipitation in May, and less than expected use of water for the fish migration (see p. 59), increased storage available in reservoirs by June 30 . These conditions were sufficient to negate plans for mandatory curtailment of electrical energy. The Bonneville Power Administration reduced power deliveries by 50 percent to consumers with interruptible service, and the aluminum industry, which uses 25 percent of the electrical energy in the Pacific Northwest, laid off 500 workers.

To conserve water and other energy sources used to generate electric power, the Governor of Idaho asked citizens to leave their air conditioners off during the summer. Many food processing plants in the State were faced with possible interruptions of power which would cause millions of dollars of spoilage to potatoes and fresh vegetables. Luckily no interruptions occurred.

Short-term feasibility studies were made by the Geological Survey of proposals to supplement irrigation supplies in the Yakima Valley of Washington. One proposal was to pump water from abandoned mines near Cle Elum, one was to divert water from the Donney Creek basin to the headwaters of the Yakima River, another was to pump ground water from the Ellensberg basin into the Yakima River, and the other was to develop additional ground water in the Ahtanum-Moxee area near the city of Yakima.
About 21,000 acre-ft could be obtained from the abandoned mines near Cle Elum during the irrigation season, but the cost was prohibitive. Use of a computer model of the Ahtanum-Moxee area showed that $450 \mathrm{ft} 3 / \mathrm{s}$ could be pumped during the summer months when demand would be the greatest. Waterlevel declines would be large, but the aquifer would recover quickly to near present levels once the heavy stress was ended.

Pumps could not be obtained in time to implement the proposed plans, but pumps are now available locally in case drought conditions return. Also, the private wells drilled in the spring of 1977 furnished additional water, especially to orchards, which fared fairly well, and the demand for water was less because some field crops were not planted. However, dry land grain production in Washington dropped to 60 percent of that in 1976 .

Low-flow discharge measurements were made in 1977 by the Geological Survey at 1,220 sites throughout the Pacific Northwest to document flows during the unusual drought. Measurements were made at active gaging stations, at discontinued gaging stations, at points where an agency has a specific interest, and at miscellaneous sites chosen to define the hydrology of the region. More than one measurement was obtained during the drought at most sites. The results of these measurements will be analyzed in relation to the longterm records, and reports will be prepared on low-flow characteristics of the streams. Water temperatures and specific conductance were also obtained.

Public utilities operating reservoirs on the Snake River in Idaho in 1977 were unable to maintain the minimum flows required by their licenses below Hells Canyon Dam and at Lime Point, upstreain from the Grande Ronde River. Because the low runoff was unusual, the Federal Energy Regulatory Commission modified the minimum flow requirements but only for the duration of the drought.

The State of Idaho received $\$ 305,000$ of federal funds for drought relief. About $\$ 196,000$ of the amount received was used to drill new wells, deepen existing wells, and to haul water-all in connection with water supplies for livestock. To provide firm domestic supplies in small communities, a few 500gallon fiberglass tanks were installed. No communities had to haul water, but newspaper 
articles contained statements that some individuals hauled water.

Municipal supplies obtained from streams in Idaho were affected by the low flows-some as early as May. By early July about 25 towns anticipated problems, and some of them had developed contingency plans. Seven towns still needed technical assistance to plan for new sources of water.

Specific hours for watering were established to reduce water used for lawns and gardens in a number of towns. Stock ponds, water holes, and some springs went dry early in the summer forcing ranchers to haul water for livestock and to reduce herds to numbers that were compatible with the water and feed available. Nyssa, on the eastern border of Oregon, began a mandatory water-rationing program on May 2, 1977.

Well-drilling activities increased significantly, particularly east of the Cascades. Ground-water withdrawals increased near Odessa, Wash., from the fall of 1976 to January 1977. Squilchuck State Park near Wenatchee, Wash., was closed in July 1977 when its spring-fed water supply was depleted.

The State of Washington started a cloud seeding project on February 28, 1977. Early results were inconclusive and by late April the results could not be readily determined though some success was claimed for increasing the snowpack in the Cascades.

The National Weather Service forecasts the times and elevations of the two high and two low stages in the Columbia River downstream from Bonneville Dam and in the Willamette River downstream from Oregon City when the stages are affected by the tides. Normally, the industries dependent upon water navigation need the forecasts only during the low-flow season each year, but in 1977 the forecasts had to be made almost all year long.

Crop sales in 1977 in Oregon topped $\$ 1$ billion for the fourth year in a row and were 5 percent higher than in 1976 despite the drought. However, sales dropped in six counties along the Columbia River primarily because of poor dryland wheat and pea production.

The governors of Idaho, Oregon, and Washington convened special task forces to coordinate activities related to the drought and to keep the public informed. Disaster designation was obtained by 49 counties in the region so that financial aid could be obtained.

\section{California-WRC Region 18}

The California Region (fig. 23) is all of California except the eastern slopes of the Sierra Nevada and the strip that drains into the lower Colorado River, and includes that part of the Klamath River basin that is in Oregon, and a small part of southern Nevada.

The more important features of the 197677 drought are presented ahead of the detailed information.

The drought in 1977 was more severe and more widespread than in either 1924 or 1976; and in much of the State, the drought in 1976 was worse than that in 1924 , based on precipitation records. The Sierra snowpack in 1976 was the lowest on record at one-third of the snow courses, but it was even lower in 1977.

The 2-year accumulated deficiencies in runoff were equivalent to the normal runoff for periods ranging from 1.1 to 2.0 years.

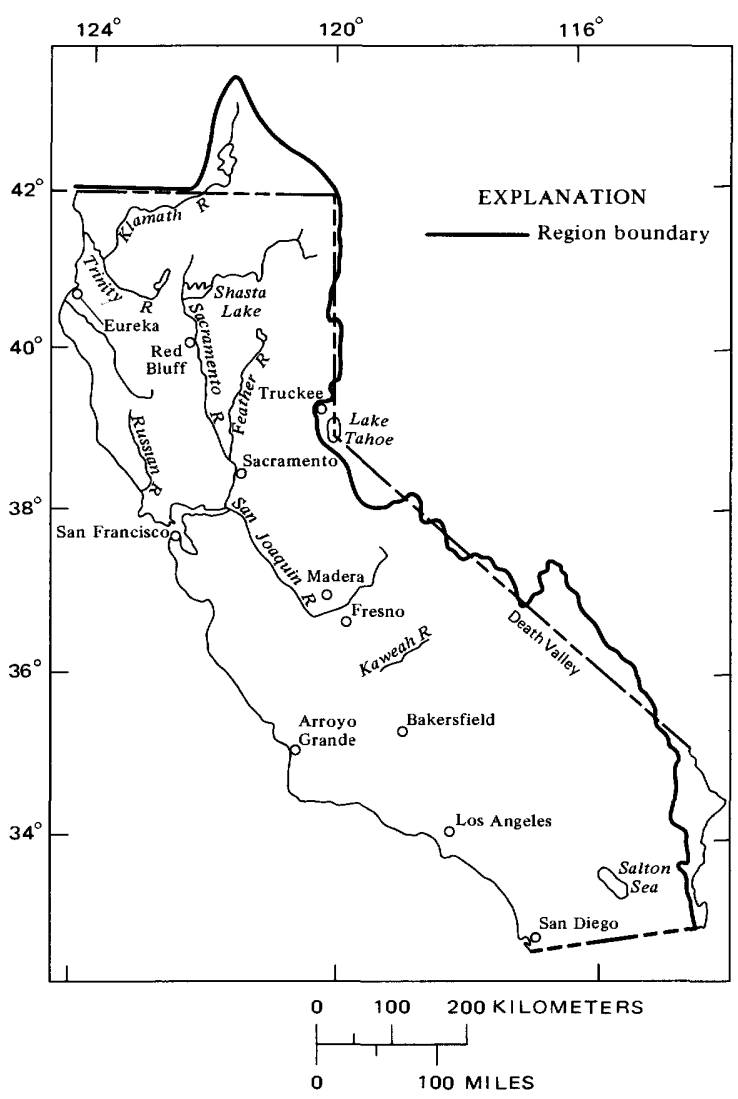

Figure 23. California-WRC Region 18. 
Heavy releases of stored water in 1976 masked the effects of the drought, and the low runoff in 1977 resulted in all-time low levels in most reservoirs in the fall of 1977 . This condition reduced hydroelectric power generation in 1977 to 30 to 40 percent of average.

Ground-water levels declined as much as 30 feet, about 40,000 wells were drilled, and the increased withdrawals of ground water caused the resumption of land subsidence in the San Joaquin Valley.

Saltwater encroached farther upstream in the Sacramento-San Joaquin Delta, chloride concentrations increased in wells near the Pajaro River, and restrictions were imposed on the discharge of wastes to maintain water quality.

Water rationing was widespread in northern California, and temporary exchanges of water were arranged to provide additional water where it was needed.

Early newspapers have accounts of droughts in 1827-29, 1856-57, and 1863-64. The latter was probably the driest of all recorded in Southern California and reduced the beef cattle industry from a major one to a minor one (California Department of Water Resources, 1976). The single driest year since records began in the early 1890 's was 1924 , and the 6- or 7-year drought ending in 1934 was the driest period recorded. The probability of occurrence of such a drought has been estimated as between 0.01 and 0.003 or on the average about once in 200 years (California Department of Water Resources, 1976).

\section{Precipitation and Runoff}

The precipitation in California for the 9year period between the 1958-66 dry period and the 1976-77 drought averaged roughly 105 percent of normal. Only 1971-72 was very dry, being less than 75 percent of average, and two dry years did not occur in succession.

The rainy season in California is between October 1 and April 30. During that period in 1975-76, precipitation ranged from 30 percent to 90 percent of normal over most of the State. Only relatively small areas had more than 100 percent, and these are desert areas where local precipitation is a minor factor in the water supply. The largest area with precipitation less than 50 percent of normal encompasses the coast from Arroyo Grande north to the mouth of the Russian River north of San Francisco, the San Joaquin Valley north of Madera, most of the Sacramento Valley south of Red Bluff, and the western slope of the Sierra Nevada. Seasonal precipitation at several locations ranked within the lowest four years of record.

The significance of the areal distribution of the much below normal precipitation is that most of the rich agricultural land in the Central Valley was affected; therefore, the demands for irrigation water increased. Also, much of the higher elevations of the Sierra Nevada was in the deficient precipitation area, and the snowpack that would normally furnish water for irrigation later in the season was well below average.

Shelton (1977) selected the precipitation records at seven cities throughout the State to provide a representative index of statewide precipitation in 1976 and 1977. The cumulative precipitation for the seven locations in 1976 was 58 percent of the cumulative averages at the same sites and that in 1977 was 54 percent. The precipitation in 1924 at these locations was 52 percent of average. At four of the seven cities, precipitation in either 1976 or 1977 was less than that in 1924; and at two cities, precipitation was less during both 1976 and 1977 than it was in 1924. Shelton concluded that the drought in 1976 was more severe and more widespread than the drought in 1924 in northern California and that the 1977 drought was more severe and more widespread than either the 1924 or 1976 drought.

Based on information published by the California Department of Water Resources (1976), the water content of the snowpack in the Sierra Nevada on April 1, 1976 was the lowest on record at one-third of the snow courses. By May 1, 1976, 68 of the 222 snow courses visited then were bare, and the water content was only 30 percent of normal in the Sacramento Valley watershed and 25 percent of normal in the San Joaquin Valley watershed. Satellite imagery showed that the snow cover in the San Joaquin River basin and the basins to the south was $2,000 \mathrm{mi}^{2}$ on May 1,1976 compared to $3,650 \mathrm{mi}^{2}$ on the same date in 1975.

The water content of the snowpack, expressed as a percentage of the April 1 average, for the Sacramento Valley and San Joaquin Valley areas is plotted in figure 24. The data 

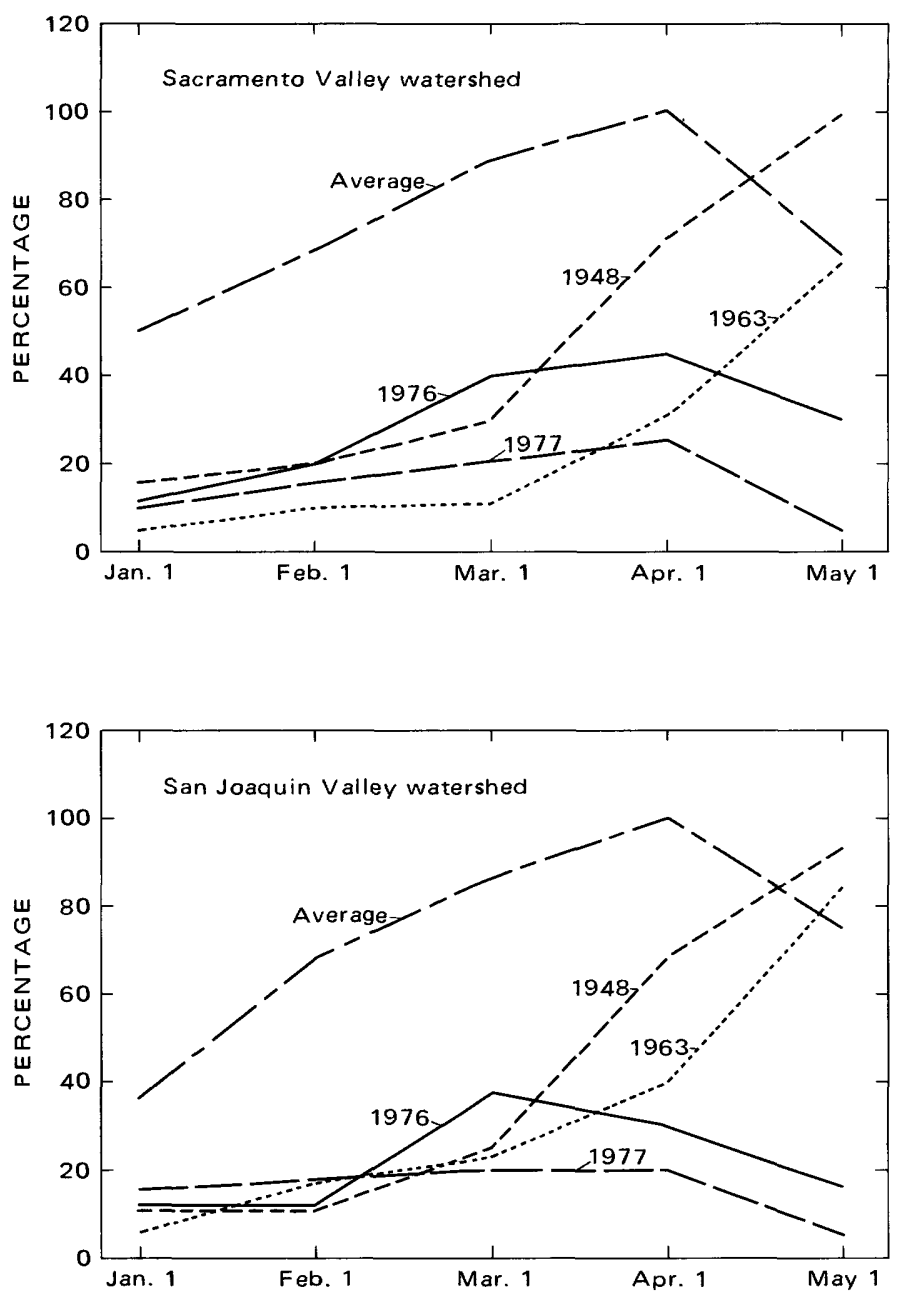

Figure 24. Water content of the snowpack in California as a percentage of the April 1 average.

for 1976 are compared with the average and with data for 1948 and 1963 , two other years with below average water content. In both 1948 and 1963, above normal increases in water content occurred in March and April to relieve the potentially severe water shortage. This did not happen in 1976; in fact, the water content of the snow in the San Joaquin Valley area decreased in March, and the increase in the Sacramento Valley area was less than normal.

Precipitation over the State during April 1977 was only 10 percent of average, and April was the seventh consecutive month of below average precipitation. The precipitation for the 7-month period, October through April, was 30 percent of average statewide. The most severe deficiencies occurred in a band across the center of the State where many new minimum records were set for seasonal precipitation.

The water content of the 1977 snowpack is also shown in figure 24 . It is less than that in 1976 after January 1 in the Sacramento Valley watershed and after February 1 in the San Joaquin Valley watershed. The water content was also less than the previous minimum for the date in both watersheds on March 1 and April 1. About 75 percent of all snow courses visited on May 1, 1977 were bare.

Not only was runoff in 1976 below normal, but the usual distribution in time of the runoff from the Sierra Nevada was distorted. According to the California Department of Water Resources, (1977b), the snowmelt started about mid-March and was virtually over in many basins by May 15; whereas, snowmelt often extends through much of July. Runoff in the Central Valley ranged from 43 percent of normal for the Feather River to 16 percent of normal for the Cosumnes River. The headwaters of the latter stream do not extend to the higher elevations of the Sierra Nevada. Most coastal streams in the central part of the State had about 10 percent of normal runoff though the Russian River did have 15 percent of normal runoff.

In 1977, the record low snowpack in the Sierra Nevada was almost gone by mid-April, but the above normal precipitation in May which added some snow, and thunderstorms in June extended the runoff period into early June. The April-July runoff for all major river basins in the Central Valley between the Feather River and the Kaweah River was at record low levels, less than 24 percent of the normal runoff. Though new low records were not set on the Tule and Kern Rivers, the 1977 runoff barely exceeded the record lows. The runoff of the Sacramento River at Shasta Dam exceeded the previous low, which occurred in 1924 , by only 72,000 acre-ft or 10 percent. The annual unimpaired runoff to the Delta from the Sacramento and San Joaquin Rivers was only 28 percent of normal.

Figure 25 is a plot of the monthly mean discharges of the North Fork American River at North Fork Dam, Calif., for the 1976 and 1977 water years plus those for two previous drought years. The distributions of flows in 1931 and 1976 are generally similar; all four years had abnormally low flows during the 


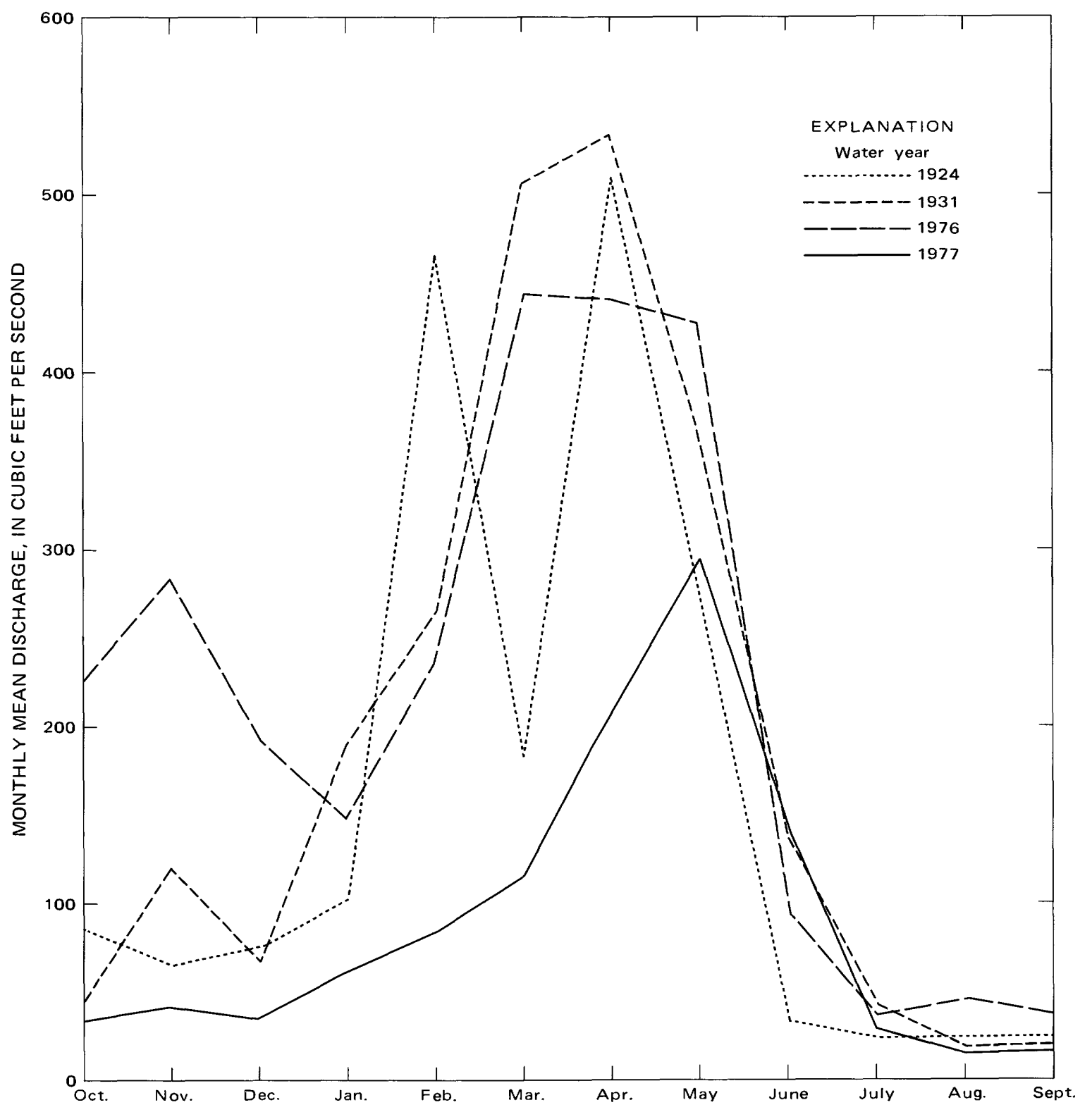

Figure 25. Monthly mean discharges for four selected drought years, North Fork American River at North Fork Dam, Calif.

winter, and the snowmelt runoff in the spring was not only much lower than normal but did not last as long; and 1977 had the most skewed distribution of flow. Except for October, November, May, June and July, the monthly mean discharges in the 1977 water year were new record minimums for the month, and those for October and May exceeded the minimum of record by less than 4 percent. The October and November minimums occurred in 1949 and 1959 , respectively. The year 1924 with 20 percent of normal runoff occurred between two years of near normal runoff, but 1931 with 26 percent of normal runoff followed two years that had 42 and 68 percent of normal runoff and was followed by a year of near normal runoff. In comparison, the runoff in 1975 was 107 percent of normal and that in 1976 and 1977 was 29 and 12 percent, respectively.

The trends in streamflow for six selected streams with natural flow in California are shown in figure 26 . The plots are of the ac- 

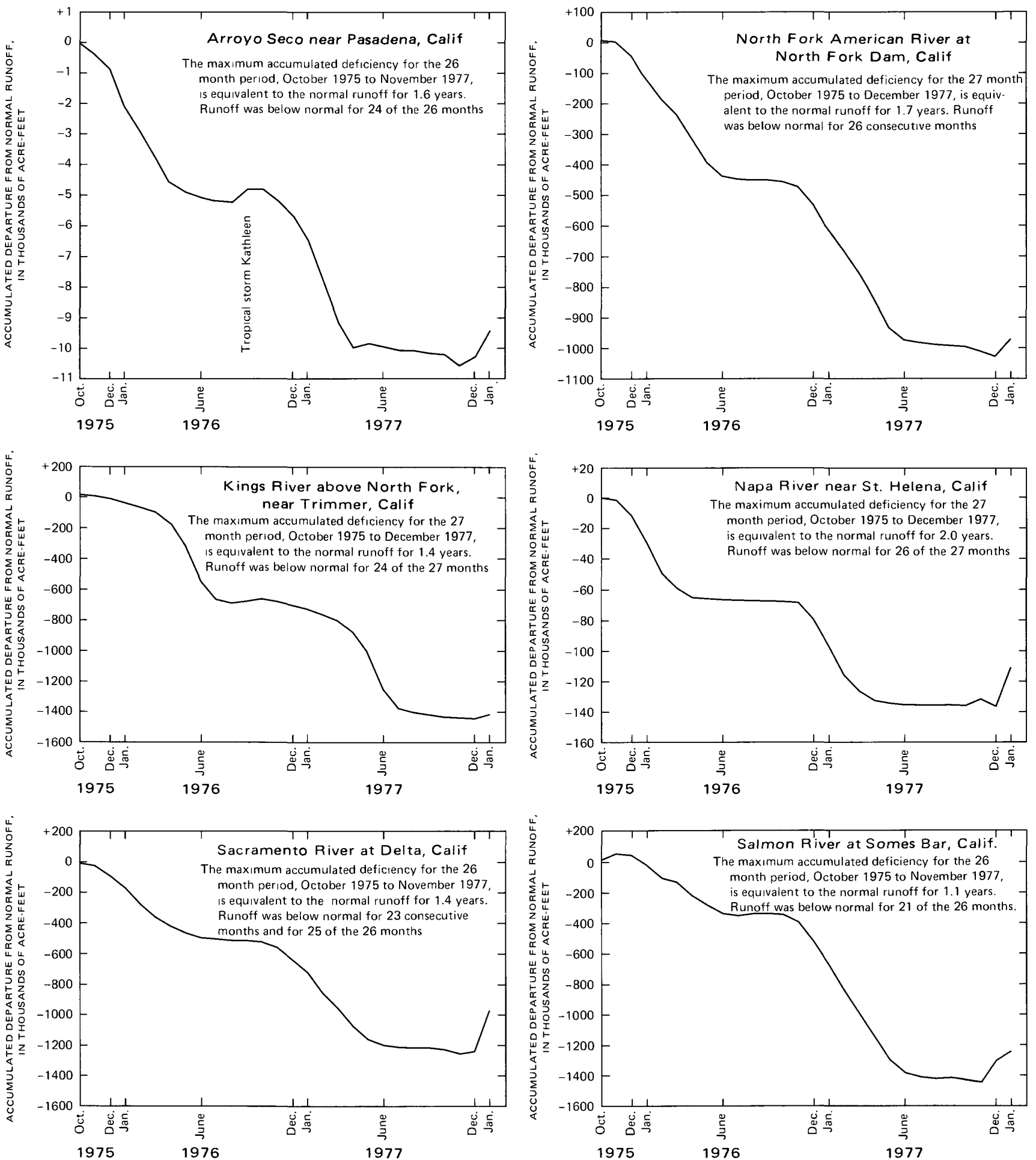

Figure 26. Trends in streamflow at selected sites in California, October 1975 to January 1978.

cumulated departure from normal runoff, in thousands of acre-feet, by months. A downward slope of the line for any period indicates deficient flow in that period. The 26- or 27- month period was based upon the month, November or December 1977, when the maximum deficiency occurred. This is the lowest point on each graph. 
The largest accumulated deficiencies were equivalent to the normal runoff for periods ranging from 1.1 to 2.0 years. The shortest period is for the Salmon River at Somes Bar, a tributary of the Klamath River on the north coast, and reflects a smaller effect in 1976. This is compatible with the nondrought conditions in the Pacific Northwest in 1976. The longest period is for the Napa River near St. Helena, a northern tributary to San Francisco Bay, where the Palmer index indicated the most severe drought conditions in the State. See figures 6 and 7. Except for the Salmon River where the accumulated deficiency in 1976 was 24 percent of that for the 2-year period, the accumulated deficiencies at the other five sites were almost equally divided between the two years. This relation does not hold for regulated streams where releases from storage were used to augment the flow, and the graphs in figure 26 should not be interpreted to indicate that the graph must rise to zero deficiency before the basin is back to normal.

The very poor snowpack in 1977 was bad enough by itself, but its damaging effects were compounded because it was the seond year in a row with a snowpack having a water content much below normal. This sequence was the reason that the water withdrawn from reservoirs in 1975 and 1976 to meet agricultural and other demands was not replaced in 1976 or 1977; therefore, reservoir levels reached alltime lows in the fall of 1977.

The April-July 1976 runoff into major reservoirs between the American and San Joaquin Rivers was either the lowest of record or nearly so. Storage in six reservoirs in the Central Valley was depleted to dead storage levels by September 30,1976 . The total capacity of 79 reservoirs in the Central Valley is 27.0 million acre-ft, but on September 30, 1976 there was only 9.8 million acre-ft in storage or 58 percent of average. Comparable figures for 74 other reservoirs in California are $7.4 \mathrm{mil}-$ lion acre-ft total capacity, 3.8 million in storage or 84 percent of average.

The depleted condition of water in storage in two reservoirs is illustrated in figure 27. Figure 27a shows the intake tower at Pardee Reservoir near Valley Springs, on the Mokelumne River southeast of Sacramento, when it was out of water on March 26, 1977. The contents was 47,300 acre-ft, only 23 percent of capacity, and the water level was $112.3 \mathrm{ft}$ below the spillway elevation which is just below the walkway to the tower.

The old U.S. Highway 99 bridge across the Sacramento River is shown in figure $27 \mathrm{~b}$. The bridge was submerged during the filling of Shasta Lake three decades ago, and it reappeared for the first time since then in 1977 . The picture was taken on September 5, 1977 when the contents was 572,900 acre-ft or 13 percent of capacity and when the water surface was $229 \mathrm{ft}$ below the top of the gates on the spillway of Shasta Dam.

Several good storms brought precipitation to northern California in September and November 1977; but even so, on December 1, 1977 the Central Valley reservoirs contained only 5.8 million acre-ft which is just 22 percent of the total capacity and 38 percent of the average for that date.

Storage in the other major reservoirs in the State dropped to 1.8 million acre-ft which is 24 percent of the total capacity and 43 percent of average for December 1.

\section{Ground-water Conditions}

Ground-water levels in a large part of California were lower in the spring of 1976 than they were in the spring of 1975 , and, in some places, they were even lower than those in the fall of 1975. A few wells located where water levels remained nearly the same had lower yields in 1976 than in 1975, and a few wells less than 50 feet deep went dry.

Declines in water levels from the spring of 1975 to the spring of 1976 were mainly in the 1- to 6-foot range; but wells in Yolo County west of Sacramento averaged about $7 \mathrm{ft}$ lower, the Madera, Tulare, and lower Kaweah and Tule River areas of the San Joaquin Valley reported declines of 7 to 8 feet, and there were declines of $23 \mathrm{ft}$ in the Shafter-Wasco area northwest of Bakersfield, and $25 \mathrm{ft}$ near Chowchilla northwest of Madera. The average decline in Santa Clara County at the south end of San Francisco Bay was $15 \mathrm{ft}$, but wells in the southern part of the county dropped as much as $30 \mathrm{ft}$ (California Department of Water Resources, 1976).

Water levels declined an additional $15 \mathrm{ft}$ by August 1976 in the northern Sacramento Valley, but they recovered about $6 \mathrm{ft}$ when rain fell in the late summer and pumping was 


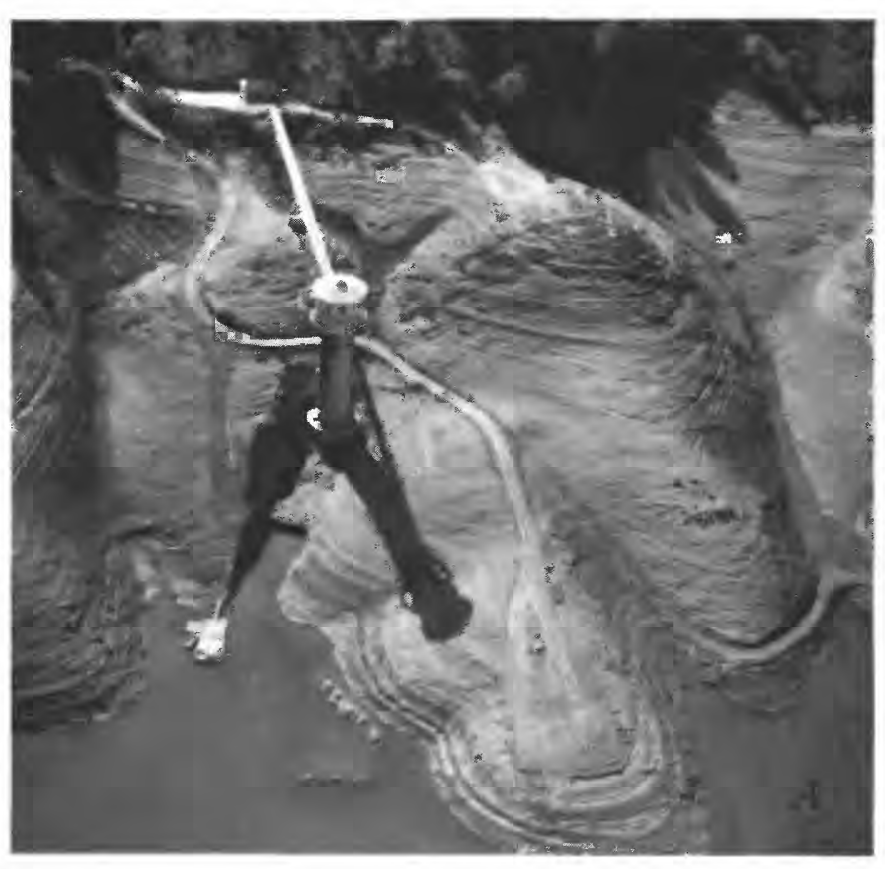

reduced. All time record low levels were reached in the lower Sacramento Valley where wells are the major source of water. In Yolo County, declines were in the $10-$ to $20-\mathrm{ft}$ range. Outside the Sacramento Valley, water levels in northern California were near normal.

The depletion of ground-water storage in the San Joaquin Valley during 1976 has been estimated as between 3 and 3.5 million acre$\mathrm{ft}$. This is about two to three times the normal annual extraction of 1.2 million acre$\mathrm{ft}$.

The additional pumping in California during 1977 increased the overdraft to 6.5 million acre-ft and caused an average lowering of ground-water levels of 13 to $20 \mathrm{ft}$. One consequence of the heavier pumping was that land subsidence resumed in the San Joaquin Valley after a 2- to 3-year cessation. Figure 28 shows the ground-water level changes from 1975 to 1977. Because diversions of Sacramento River water were restricted in the summer of 1977, irrigators drilled new wells; and some of these were close enough to the river that they probably drew water from the river. The relative amounts drawn from the river and from the ground-water body have not been determined (California Department of Water Resources, 1978).

The drought affected runoff in the Owens Valley area in the eastern Sierras where the



Figure 27. Depleted conditions of water in storage in two reservoirs.

intake to the Owens Valley aqueduct of the city of Los Angeles is located. Los Angeles sought permission to about double its pumping from the Owens Valley ground-water basin, but pumping was limited by a court injunction until the effectiveness of the water rationing program was demonstrated. This was done, and increased pumping from deep wells started on August 1, 1977 and provided an additional 10,000 acre-ft per month for 8 months.

The decreased use of surface water was partly offset by increased use of ground water. The cooperative way that water managers operated ground-water basins throughout southern California was beneficial to all of southern California as well as the entire State. However, the managers are now concerned over significantly lower water levels, many of them being at all-time lows. The 2-year overdraft is estimated as 500,000 acre-ft (E. L. Griffith, 1978).

The number of reports received by the State of wells put into operation was 8,300 in $1975,11,200$ in 1976 , and 20,000 in 1977 . Because all wells drilled are not reported, the total for 1977 has been estimated as 28,000 wells.

$$
\text { Water Quality }
$$

The reduced inflow into the SacramentoSan Joaquin River Delta allowed the saltwater 


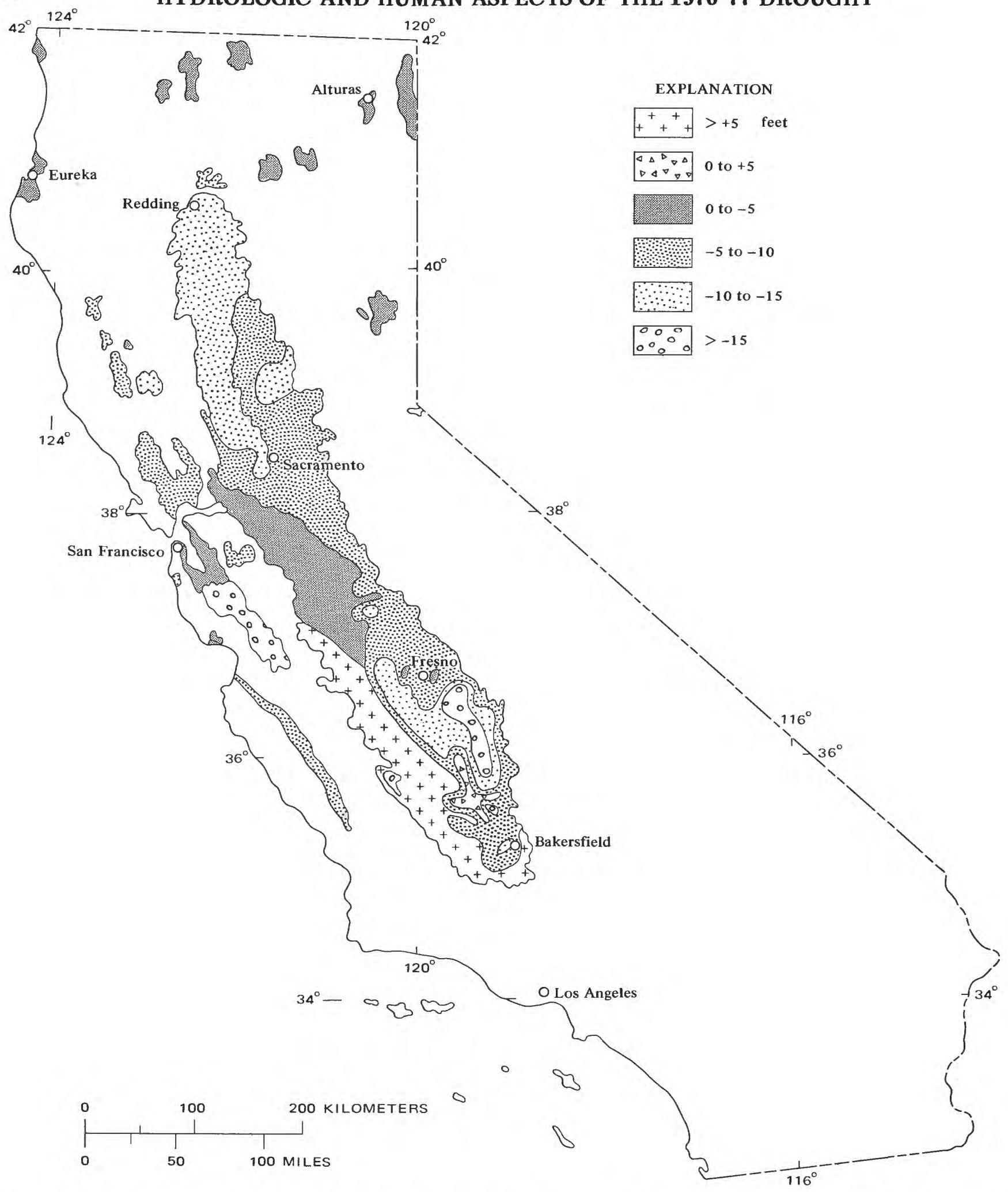

Figure 28. Ground-water level changes, 1975-77, in feet. Adapted from California Department of Water Resources (1977c). 
of the San Francisco Bay system to encroach farther upstream than usual. The point of maximum encroachment is defined as the point farthest upstream where the chloride concentration reaches $1,000 \mathrm{mg} / \mathrm{L}$ (milligrams per liter). Water of this salinity, when used for irrigation over a considerable period of time, will severely inhibit the yield of most crops. Comparative chloride concentrations are $19,000 \mathrm{mg} / \mathrm{L}$ for sea water and near $7 \mathrm{mg} / \mathrm{L}$ for Sacramento River water.

Figure 29 is a map of the Delta showing the maximum intrusion of salinity for selected years, including 1976 and 1977. The encroachment shown for 1931 and 1939 , two dry years, occurred prior to the completion of Shasta Dam in 1944. Since then, fresh water has been released from Shasta Lake to repel the salinity. In 1952 and 1958, heavy flood runoff occurred, and 1966 was a dry year, 75 percent of average runoff, before the completion of Oroville Dam in 1968. Runoff in 1975 was 113 percent of average.

Runoff into the Delta dropped to 60 percent of average in 1976 and to 28 percent of average in 1977 . The salinity intrusion advanced about $7 \mathrm{mi}$ in 1976 from the position in 1975 and about $4 \mathrm{mi}$ more in 1977 . To halt the saltwater encroachment in parts of the Delta, temporary earthfill barriers were erected in 1977 across several channels in the Delta. A pumping plant was built to provide higher quality water to the Contra Costa Canal, and several diversions were changed on an interim basis to points upstream to tap better quality water for use within the Delta.

Operations of the upstream reservoirs of the State Water Project and the Federal Central Valley Project are coordinated to provide water in the Delta for local consumptive use, for exports by the State and Federal projects, and to maintain water-quality standards set by the State Water Resources Control Board. Twice during 1977 , once on February 8 and again on June 2, the water-quality standards were modified so that less water was required for Delta outflow, thus conserving the short supplies upstream so that they would be available later in the season to protect the water quality in the Delta.

Seawater intrusion raised the chloride concentrations in wells near the mouth of the Pajaro River near Watsonville, Calif., about 70 $\mathrm{mi}$ south of San Francisco. The lack of recharge and the increased pumping during the drought caused water levels to decline an average of $10 \mathrm{ft}$ between November 1975 and November 1977. Under normal conditions, the water levels rise during the winter months to elevations above sea level; but throughout the drought, the water levels in most wells remained below sea level.

This adverse gradient was not sufficient to cause the intrusion to advance any farther inland than approximately $1 \mathrm{mi}$ which was also observed in 1974, but the increases in chloride concentrations were dramatic. In a well perforated in the $100-$ to $200-\mathrm{ft}$ interval, the chloride concentration rose from $114 \mathrm{mg} / \mathrm{L}$ in November 1975 to $571 \mathrm{mg} / \mathrm{L}$ in November 1977. The maximum increase in a well tapping the aquifer at the $300-$ to $600-\mathrm{ft}$ level was 100 $\mathrm{mg} / \mathrm{L}$ to a high of $229 \mathrm{mg} / \mathrm{L}$.

The use in gardens, etc., of "grey water" from bathing, dishwashing, and laundering was approved in some localities and banned in others as detrimental to public health. The State Water Quality Control Board imposed restrictions in April 1977 on several communities discharging sewage effluent into the Russian River because most of the fresh water released from storage near the headwaters was diverted and the waste discharged into the river exceeded the controlled flow in the downstream reaches. In southern California, reclaimed water has been used for irrigation and for recharge to aquifers, but the use of less fresh water increased the salinity of effluents enough to make it less desirable or even unusuable for recycling.

High water temperatures associated with low flows in September 1977 caused a fish kill in the Trinity River below Clair Engle Lake. The water temperature rose almost $9^{\circ}$ to $70^{\circ} \mathrm{F}$ which is warm for trout.

\section{Land Subsidence}

Subsidence is a problem in the San Joaquin and Santa Clara Valleys. It is directly related to hydraulic stresses induced by ground-water pumping and the resulting compaction of water-bearing deposits. After three decades of pumping overdraft and water-level declines, the widespread subsidence in the San Joaquin Valley was halted or significantly reduced after 1968 when imported canal water replaced ground-water pumpage. The drought of 


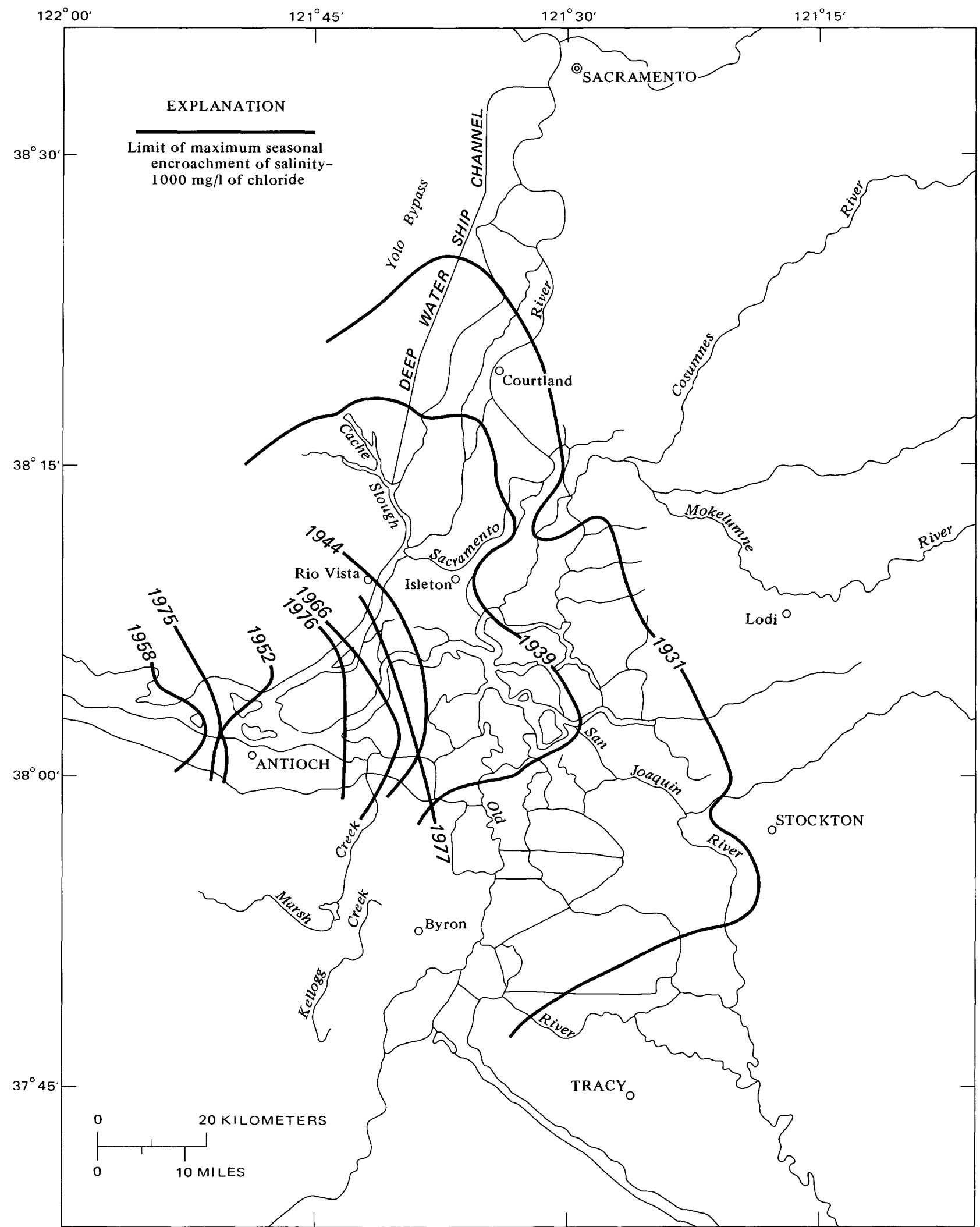

Figure 29. Map of Sacramento-San Joaquin Delta showing annual maximum intrusion of salinity for selected years. Adapted from Bureau of Reclamation. 
1976-77 reversed the trend because the increased use of ground water to meet the demands for water initiated another period of pumping overdraft and the resumption of subsidence (Lofgren, 1977).

Subsidence causes significant changes in storage characteristics of an aquifer system during the first cycle of water-level decline. Pore water is squeezed from the water-bearing deposits, and permanent compaction occurs in the fine-grained beds. Therefore, the pore space available for storage is reduced, and pumping rates that occurred in 1977 will lower the water levels much faster, possibly 10 to 20 times faster, than the same rate of pumping would have caused during the first cycle that ended in the late 1960 's.

\section{Hydroelectric Power Generation}

Hydroelectric power generated in northern and central California is an integrated operation of 105 hydroelectric plants. Virtually every plant was adversely affected by the drought of 1976-77. Only a few plants were actually shut down for lack of water, but at other plants the hours of operation were reduced and the capability of the generators at variable head plants decreased because of low heads. The significant result was that hydroelectric generation in 1977 was 10 billion kilowatt-hours; whereas, the average output is 24 billion kilowatt-hours. The deficit of 14 billion kilowatt-hours was directly related to the drought, and the replacement of most of the deficit by purchases from other electric utilities and additional use of steam generating plants increased production costs to one utility by $\$ 326$ million (E. F. Kaprielian, written commun., 1978).

The major hydroelectric development in the southern Central Valley is in the upper San Joaquin River basin. Hydroelectric power generation by this project averages 3.5 billion kilowatt-hours; but in the 1976 water year, output was only 2.5 billion kilowatt-hours and in 1977 it dropped to 1.1 billion kilowatt-hours. The snow and rain that fell on the watersheds in 1976 was not enough to produce the 2.5 billion kilowatt-hours; therefore, heavy demands were made on water in storage which was not replaced during the winter of 1976-77 when precipitation was very low. The system still met peak demands for short periods only because special operating schedules were developed by careful planning. The cost to replace the 2-year deficit of 3.4 billion kilowatt-hours was $\$ 85$ million.

Hydroelectric power generation at several small plants on streams without storage is usually reduced when the snowmelt runoff ceases. In both 1976 and 1977 power generation had to be curtailed earlier than usual.

\section{Forests}

The drought conditions caused the fire season to start early. The larger fires of the 13,300 fires that occurred in California in 1976 were in June and July. Forest fires usually burn about 25 percent of the amount burned annually by July 15 ; but 85 percent of the 194,000 acres burned in 1976 had been burned by then. In September 1977, the California Departinent of Forestry estimated damage to timber and watersheds by recent fires at $\$ 250$ million. About 1,850 fires occurred in California in August 1977, burning in excess of 410,000 acres, and the 11,900 fires in 1977 burned 449,000 acres.

The loss of trees because of the two-year drought was tremendous. About six million trees that could be used for commercial timber died from drought-induced afflictions. This loss has been estimated to be between 2.5 and 3.8 billion board feet of marketable lumber.

The fire that started in the hills near Santa Barbara, Calif. spread into areas with expensive homes and caused millions of dollars of damage.

\section{Activities Resulting from the Drought}

The Director of the California Department of Water Resources (Robie, 1978) reported that more than 100 communities in California adopted some form of mandatory rationing during 1977. Allowances were as low as 50 gal/d per person. Statewide urban consumption was 20 percent less than that in 1976 , but communities on the Monterey Peninsula and in the Marin Municipal Water District reduced water use by 49 and 53 percent, respectively, during the first 9 months of 1977 compared to the same period in 1976 . The reduction in water use in 1977 was slightly more than 400,000 acre-ft which exceeds the projected 
annual yield of the Auburn Dam project, a major water development in the Sierras east of Sacramento.

Water exchanges were arranged by the Department of Water Resources to distribute the available water supplies more equitably. The Metropolitan Water District of southern California reduced its demands on the State Water Project by 400,000 acre-ft and used additional water from the Colorado River. The water that would have gone to southern California was delivered to agricultural users in the San Joaquin Valley and to urban users in the San Francisco Bay area. This exchange made it possible for farmers served by the State Water Project to receive 91 percent of their 1977 entitlement instead of about the 40 percent they would have received without the exchange.

The Metropolitan Water District normally supplies about 6 percent of Los Angeles' needs but supplied about 25 percent in 1977. The District offered an incentive rebate to member agencies of $\$ 20$ for each acre-foot of water conserved in 1977 below 90 percent of their 1976 use of surface supplies. None of the 27 agencies failed to meet its new allotment. Actually, an additional saving of 180,000 acre$\mathrm{ft}$ was accomplished at a cost to the district of over $\$ 3$ million.

Farmers pumped ground water into the California Aqueduct where its quality was compatible with the canal water. The pumping took place during periods of low water use by the farmers, and the water was stored in the canal until it was needed.

The Department of Water Resources, the Department of Fish and Game, and the owners of several duck clubs in the Suisun Marsh, between San Francisco Bay and the Delta, shared the cost of bringing higher quality water into a local wildlife management area. Soil salinity was reduced; therefore, the production of waterfowl food was improved.

The State Water Resources Control Board directed large water suppliers to maintain reserves in upstream storage facilities to protect against another dry year in 1978 .

Forty-seven of California's 58 counties and 4 counties in Oregon were declared disaster areas, and anyone who suffered losses because of the drought was eligible for financial assistance. Also, Governor Edmund G. Brown, Jr. created the Governor's Drought Emergency
Task Force on March 4, 1977. The task force was responsible for the direction and coordination of State efforts to combat the drought and for the education of citizens regarding the nature and extent of the drought.

The activities mentioned herein are only a few of the many activities that occurred in California, but they are types that illustrate that when a crisis develops, agencies and individuals can cooperate to alleviate adverse conditions to everyone's mutual benefit.

\section{Hawaii-WRC Region 20}

There are eight islands in the state of Hawaii, but information in this report is related to the five major islands, Kauai, Oahu, Molokai, Maui, and Hawaii (fig. 30). The topography of the islands causes an extreme range in precipitation from about 13.5 in. annually near sea level on Maui to 486 in. at Mount Waialeale in the center of Kauai, one of the world's wettest spots. With this wide a range, the departure from average at some locations can be more than the total annual precipitation at other sites. Also, the average precipitation is markedly different over short distances as the greatest distance from the coast to the center of an island is only $42 \mathrm{mi}$ on the island of Hawaii. Under these conditions, the existence of a drought is difficult to determine.

\section{Previous Droughts}

A drought started to develop in the winter of 1951-52 when only one soaking rain occur-

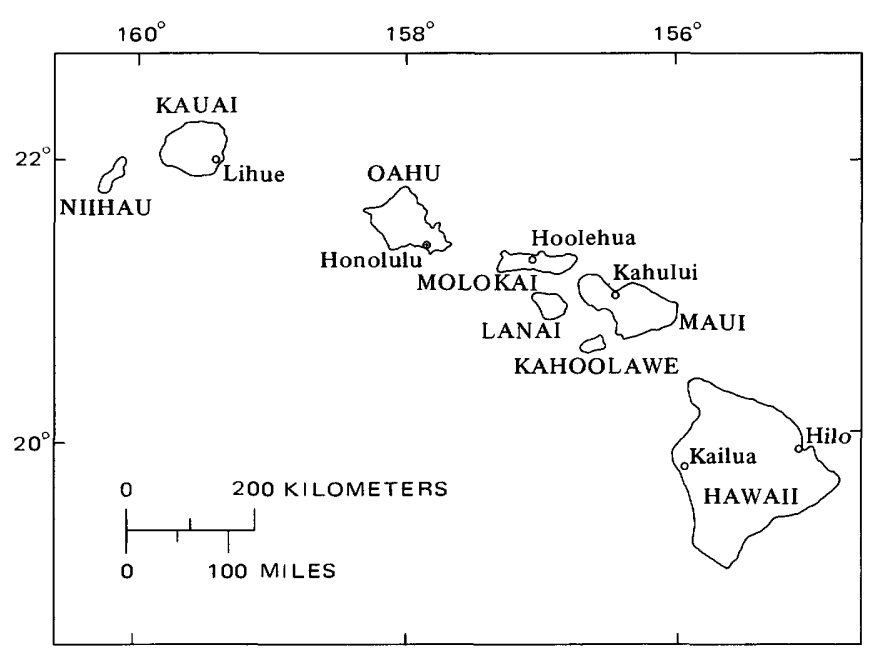

Figure 30. Hawaii-WRC Region 20. 
red. Rains carried by the trade winds provided adequate water between February and June 1952 except on Molokai where precipitation was less than half of average. The late summer was dry and so was the early winter. Pastures on Molokai and Maui were brown, and truck crops wilted. Some wells ran dry or became brackish, and drinking water was being trucked from higher elevations to the Kona area, on the west coast of Hawaii. January 1953 was very dry with Maui receiving only 10 percent of normal rainfall. Ground water was pumped into the elaborate ditch system on Maui to provide flows near a quarter of its capacity. Thunderstorms in mid-February brought some relief, but the drought continued throughout the summer of 1953.

At Waipahu, Oahu, near Pearl Harbor west of Honolulu, monthly rainfall was well below normal for 18 of the 21 months from January 1952 through September 1953. This record indicates the lack of the usual number of or substantial Kona storms which are the widespread storms that usually occur during the winter. The deficient rainfall from the trade winds during the rest of the year is indicated by the record at Luakaha in the mountains back of Honolulu where rainfall was below normal in 12 of the same 21 months and in 6 of the last 7 months. Rains in October and November 1953 ended the drought. Previous record low rainfall had been in 1921 on Kauai, in 1933 on Oahu, and in 1917 on Maui and Hawaii.

What was called a dry spell by some and a drought by others occurred in the summer of 1971. Maui was particularly hit hard, and less severe conditions existed on Hawaii, Molokai, Oahu, and Kauai. The major cause was the absence of normal rainfall from the trade winds that bring moisture to the higher elevations on the windward sides of the islands.

There are no ground-water sources on East Maui to supplement a shortage in the streams; therefore, when the number of rainy days and the amount of rainfall were reduced significantly, drought conditions existed. Irrigation and domestic uses were sharply curtailed on Maui and Hawaii, water was trucked to families on Molokai and to irrigate macadamia nuts on Hawaii, temporary pumps were installed to raise water from a low elevation reservoir into a higher level ditch system on Maui, and planting of sugar cane was delayed until sig- nificant rains occurred. Rains ended the drought in September 1971.

The May through August 1971 precipitation at Waikamoi Dam on East Maui was the lowest since records began in 1911 and was 30 percent of normal as compared to 40 percent in 1953 . The 4-month rainfalls at other Maui sites were in the range of 19 to 52 percent of normal.

\section{Precipitation and Runoff}

Precipitation for 1975 at the four index stations on the four larger islands ranged from 75 to 107 percent of normal. The below normal trend started about March 1975 with the bulk of the deficiency occurring during the summer and fall. Even the 107 percent of normal at Honolulu was caused primarily by almost four times the normal rainfall in November whereas 10 of 12 months in 1975 were below normal.

Rainfall was below normal during 11 of the 12 months in 1976 at Honolulu, Oahu and Kahului, Maui. Only February was above normal. Precipitation was deficient for 9 of the 12 months at Hilo, Hawaii and for 8 of them at Lihue, Kauai. At Honolulu, only 15 percent of the normal rainfall occurred during the period September through December 1976, and December with only 0.06 in. was the driest December in the 100-year period of record.

Below normal precipitation continued into March 1977, then above normal precipitation in April on all the islands and in May and June on Kauai and Oahu relieved the drought conditions to some extent. But the pattern of below normal rainfall was reestablished in July and continued through December.

Runoff during the last 8 months of 1975 was below normal on the islands of Hawaii and Kauai and was normal for most of that time on Maui and Oahu. Deficient runoff conditions continued into 1976 and became serious enough by August 1976 to be considered a drought which persisted to March 1977. Runoff increased in April and in May on Kauai and Oahu in response to the above normal precipitation, and was again generally deficient from July through December 1977.

\section{Ground-water Conditions}

Water levels in five observation wells declined to record low levels. Three of the mini- 
mum levels were reached in March 1977 on Maui and two in late August or early September 1977 on Oahu. Both basal water tables and a high elevation aquifer are represented in this sample. The record on the latter started in 1936. Though water levels were very low, no significant reductions in water yield occurred.

There was no significant increase in the number of wells drilled in 1976 or 1977.

\section{Water Quality}

The chemical quality of surface waters did not change significantly during the drought. Dissolved-solids concentration increased slightly, but sediment concentrations and discharges decreased. The sediment discharge during the 1977 water year of Waikele Stream into Pearl Harbor was one-ninth that of the previous year.

Though flows were less, stream water temperatures were near seasonal normals.

\section{Activities Resulting from the Drought}

The below normal runoff produced the most serious problems in the areas that have no development of ground-water resources such as East Maui. The areas that rely on surfacewater supplies and limited water storage facilities were hard pressed to meet the demand. The Kona area on the island of Hawaii was declared in a state of drought emergency in January 1977. Water was hauled to families in the area, lawn watering and car washing were prohibited, macadamia nut growers were asked to reduce the amount of water used for irrigation, and cattle ranchers had less water for their livestock. Similar constraints were imposed on most of Maui where residents were asked to reduce their water consumption by 30 percent, and the truck farmers were limited to two irrigations per week.

The least effect was on Kauai. No state of emergency was declared, but sugar cane growers hoped for rain to supplement the diminished flows in the irrigation systems.

On Oahu, requests were made to cut water use by 10 percent for residential use, by 15 percent for commercial and agricultural uses, and by 50 percent on parks and golf courses. Though no drought emergency was declared in 1977 , the Honolulu Board of Water Supply proposed rules and regulations to initiate manda- tory water conservation measures in the summer of 1978 , if necessary.

\section{The Eleven Other WRC Regions}

Seven of the other eleven WRC regions stretch from Maine to California, along the Atlantic and Gulf coasts, and along the Mexican border. Two are interior regions, the Ohio and the Tennessee regions, and the other two regions are Alaska and Puerto Rico.

There was no or virtually no drought in three regions; New England, Region 01; Lower Mississippi, Region 08; and Alaska, Region 19. In six regions, Ohio, Tennessee, Texas-Gulf, Rio Grande, Lower Colorado, and Caribbean, respectively Regions $05,06,12,13,15$, and 21 , the effects of the drought were relatively minor-either in localized areas or for short durations similar to other dry years. The MidAtlantic, Region 02 and the South AtlanticGulf, Region 03, had more serious drought problems in small parts of the regions. Brief descriptions of the conditions in Regions 02 and 03 and a few highlights from the other Regions are presented in this section.

Previous droughts have been described by many writers, among them Barksdale and others (1966), Benson and Gardner (1974), Gatewood and others (1964), Hoyt (1936, 1938), Nace and Pluhowski (1965), Thomas and others (1963a-d), and Water Resources Council (1966). Palmer and Denny (1971) have compiled a bibliography of other drought reports.

\section{Precipitation and Runoff}

Four months of deficient rainfall from April to July 1977 was the primary cause of drought conditions in South Carolina. Runoff during the previous winter was near normal, but the dry period started about 2 months earlier than usual, thus causing adverse impacts on agriculture. Rain in early August prevented a severe drought from developing.

Deficient rainfall in Georgia and the longer than usual intervals between rains, some as long as 8 weeks, caused farmers to delay their planting of crops because moisture is needed to activate the chemicals in pesticides and weed control agents. Monthly rainfall in April and May in southwest Georgia usually exceeds 4 in.; but rainfall in April 1977 was only 1.29 in., and during the first 19 days of May it was only 0.33 in. 
Streamflows in Maryland and Delaware were below normal during the summer of 1977 and generally were the lowest since 1970 , but they were well above the minimums of record, many of which occurred during the summer of 1966. The exception was the Choptank River near Greensboro, Md., $65 \mathrm{mi}$ east of Washington, D.C. where new monthly minimum flows occurred in May, June, and July 1977, and the flows were in the deficient range for 7 months from February to August 1977.

There was much publicity and concern in the Washington, D.C. area when the flow of the Potomac River near there dropped to 40 percent of normal during May and June 1977. However, enough rain fell in the basin during the summer to maintain the flow at more than three times the diversion rate for municipal supplies.

The drought in Virginia was the most severe in the north, central and eastern parts of the State in 1977. The September runoff of the Rapidan River near Culpeper, about $65 \mathrm{mi}$ southwest of Washington, D.C., was the sixth lowest flow for September since records began in 1930. The lowest September flow occurred in 1954 when it was a fourth of that in 1977.

In North Carolina the drought was not continuous, but the eastern half of the State was affected in both 1976 and 1977. Streamflow was below normal from March through September 1976 and was near the minimum of the last 50 years. Deficient streamflow occurred again from April through mid-August 1977.

Flows of some streams in South Carolina in July 1977 receded to the level where the 7-day average flow reached recurrence intervals of 2 to 6 years.

Runoff and precipitation in New Mexico are not very high in normal times, but the below normal precipitation and runoff reduced the storage in major reservoirs that provide water for irrigation to less than 50 percent of average in December 1977.

\section{Ground-water Conditions}

In several States, some wells went dry or did not yield enough water, but the main problems were related to the wells rather than the ground-water supply. Wells were not deep enough, or not in a very good location, or had not been developed correctly after they were drilled.
Water levels in North Carolina were generally below normal from June through September 1976 and about the same period in 1977 . However, no serious ground-water deficiencies developed.

The use of ground water for irrigation in Georgia is a "whole new use" of that resource according to the State Geologist. Some shallow wells in southern Georgia went dry when overpumped. Therefore, the Governor ordered a survey of ground-water consumption as an early step toward the development of a coordinated water and land use policy. There was also concern that the large number of new wells drilled and the increased withdrawals might overtax the ground-water resource.

\section{Water Quality}

The severe winter of 1976-77 in the eastern United States coupled with below normal runoff caused an increase in the ice cover on streams and lakes-both in thickness and areal extent. Fish kills occurred in some ice covered streams and stock ponds.

These factors also affected the flow of the lower Mississippi River and the position of the freshwater-saltwater interface which is where the chloride concentration reaches 5,000 $\mathrm{mg} / \mathrm{L}$. At Baton Rouge, La., the discharge dropped to $175,000 \mathrm{ft} 3 / \mathrm{s}$ in October 1976 , but this was $100,000 \mathrm{ft}^{3} / \mathrm{s}$ more than the minimum flow of record in 1939 . On October 6, 1976, the leading edge of saltwater had intruded 57 mi up the Mississippi River to Myrtle Grove, but increased flows pushed the leading edge downstream $24.5 \mathrm{mi}$ by October 20 and $46 \mathrm{mi}$ by November 12 . With flows under 200,000 $\mathrm{ft} 3 / \mathrm{s}$ starting on November 20,1976 , the leading edge moved back upstream $14 \mathrm{mi}$ by midDecember and reached a point $47 \mathrm{mi}$ above Head of Passes by mid-August 1977. It receded to river mile 11 again by September 28, 1977. The penetration of saltwater as far as Myrtle Grove has a mean recurrence interval between 5 and 10 years.

Communities along the lower reach of the Mississippi River that use river water for their supply had to import freshwater to dilute their supply to acceptable levels.

\section{Activities Resulting from the Drought}

Crop damage in Virginia was high, and municipal water supplies were dangerously 
low. Restrictions on water use were in effect during the late summer of 1977 mainly in northern Virginia.

In the summer of 1977 , the drought severely stressed the water-storage facilities of a few municipalities in eastern North Carolina where the facilities were known to be marginal, before the drought. Restrictions on water use were imposed and the water shortage at Chapel Hill in north-central North Carolina was severe. The city of Raleigh completed a 3.4 billion gallon auxiliary reservoir late in 1976 which filled during the winter and prevented a recurrence of the water shortages of 1976. Orange County which includes Chapel Hill formed a water and sewer authority to plan long-term solutions to their water supply problems. In the meantime, they planned on auxiliary supplies from new wells and possibly a pipeline from the Haw River. The North Carolina Department of Natural Resources and Community Development evaluated the adequacy of water supplies statewide.

Farmers in Georgia who raised soybeans, peanuts, and other crops became interested in irrigation for the first time in more than 20 years because rainfall was deficient and there were intervals between rains extending to 8 weeks. The farmers who suffered financial setbacks in 1977 because of the drought planned significant capital outlays for irrigation systems to prevent a similar setback in the future. Pecan, corn, peanut, and soybean production was affected by the drought more than the tobacco and cotton crops. Hay was cut early in 1977, but none later in the season because the pastures burned up for lack of rain. Army worms infested corn in Georgia and Alabama.

Some water for irrigation was obtained by draining farm fish ponds, but this impaired the raising of fish for food. One farmer attended so many fish fries that he lost his appetite for fish!

The drought in Puerto Rico started in March 1977 and ended in October 1977, but it was not much different than the drought in 1974. Water rationing began on April 14 on a voluntary basis, became mandatory on June 17 , ended in some areas in August and the rest in October. Rationing was accomplished in a different manner; namely, by the public utility shutting off all supplies between 9 p.m. and 6 a.m. except to vital service units. The local people adjusted to drought conditions since they have had to in the past, but the tourists had problems. Cattlemen's costs rose when they had to buy feed for their cattle because the pastures dried up.

The Virgin Island's main water supply is desalinized water; therefore, the impact of the drought was felt mostly in the rural areas. Pastures dried out, and cattlemen had to buy feed for their stock.

Farmers in the Middle Rio Grande Valley in New Mexico received water from the Colorado River basin through the San Juan-Chama Project, thus averting serious effects from the deficient precipitation. Several municipalities instituted mandatory water conservation practices and limited water use.

Many counties in most of the States were declared disaster areas.

\section{Epilogue}

The drought of 1976-77 may be over or it may be only interrupted. Precipitation between September 1977 and January 1978 was above normal in most of the western United States. A few ski resorts had operational problems caused by snow depths up to 150 percent of normal for January, and very stormy conditions closed mountain highways and airports.

However, the wet period that began in September 1977 ended about mid-January 1978 along most of the west coast when the high pressure system moved northward and just off the coast forcing the storm paths to bypass the area to the north. The more northerly storm path brought cold arctic air into the Midwest causing blizzards and very cold weather-a partial repeat of the severe winter of 1976-77. Since January 1978 precipitation has been generally above normal, and drought conditions have almost disappeared.

The fall and winter rains of $1977-78$ were welcome events. The persistence and, at times, the intensity of the precipitation were sufficient to increase streanflows into the normal or above normal regimes. The runoff replenished nearly depleted supplies in reservoirs. For example: Storage in 10 of the larger reservoirs in California increased by 3.3 million acre-ft in January 1978. The water content of the heavy snowpack was enough to make releases of recently stored water neces- 
sary to preserve enough space for flood control if needed later in 1978 at a few sites in California, Oregon, and Washington.

Ground-water levels, particularly in California, were still below average; and more than a few months' time is needed for groundwater levels to respond to normal or above normal precipitation and runoff.

Water rationing has been abandoned in most locations, but many water rates are higher than they were before the drought.

Looking back on the drought, its impacts, and the adaptations made, a very brief summary of an important human aspect in relation to the drought is contained in a statement that someone made that did not characterize the drought, per se, but expressed a view of the overall conditions very well. The statement is "The year 1977 can be remembered as the year of cooperation and compromise."

\section{SUMMARY}

Preparation of a summary of the drought of 1976-77 is analogous to picking up mercury with one's fingers. There were so many aspects that changed with time and location, that an adequate summary would be overlong; therefore, this summary will include only the more important aspects of the drought.

The brunt of the drought was felt in both or parts of 1976 and 1977 over large parts of the United States; however, drought effects began to develop in the Midwest in 1974. The record low amounts of precipitation in many localities and the longer than usual intervals between rains seriously affected non-irrigated crops, yet in a number of areas enough rain fell at the right time during the growing season to produce respectable crop yields. The record low snowpacks, particularly in the Sierras in California, and in the Cascades in the Pacific Northwest and the Rocky Mountains caused record low runoff in many western streams. The use of carry-over storage in reservoirs cushioned the impact in 1976, but surfacewater supplies were insufficient to meet all demands in 1977.

The very cold winter of 1976-77 in most of the eastern part of the country compounded the problems. All these factors made the drought of 1976-77 the most severe one in at least 50 years in many parts of the country.
Ground-water level declines greater than those in earlier years occurred in many area as ground water was used to supplement the dwindling surface-water supplies. Wells went dry, yields diminished, and thousands of new wells were drilled. Despite the added stresses on the aquifers, very few serious water-quality problems arose. The increased withdrawals of ground water in the San Joaquin Valley of California brought on a renewal of land subsidence.

Most water-quality problems were localized and of relatively short duration. Some were anticipated and other were not. Though water in storage was in short supply, there was enough flexibility in most water development systems that additional releases from reservoirs were made to dilute or flush stream reaches to reduce or eliminate any degradation in water quality that became serious.

Water rationing was common in all areas except in the Pacific Northwest where only a few towns introduced rationing. Trucking of water to users and trucking of cattle to water occurred in many States. Legal constraints on water use were modified on temporary bases to provide more water where and when it was needed. Emergency funds were made available to truck cattle or for pumps, pipes, and equipment for emergency water supplies. The public was educated by various agencies and the media on the seriousness of the drought and on how to conserve water.

The water systems constructed since the "Dust Bowl Days" of the 1930's, the development of better machinery, better strains of corn, wheat and other crops, better management of irrigation water, and better farming practices contributed to reducing the adverse impacts upon people during the drought of 1976-77 as compared to earlier droughts.

The cooperation of agencies and individuals at all levels of government and in the public sector to alleviate drought related problems was encouraging in spite of some unsucessful efforts. The outlook for coping with a drought in the future is an optimistic one.

\section{A LOOK TO THE FUTURE}

The writer does not claim any abilities to predict droughts in the future, though the National Oceanic and Atmospheric Administration has reported (Upper Mississippi River 
Basin Commission, 1977) that there is a tendency toward a higher risk of drought in the 1990 's than in the 1980 's, but a drought may come in the 1980 's. A number of facts, ideas, plans, programs, and intentions for the future have been accumulated, discussed, and proposed because of the drought of 1976-77, and some of these are presented below. Man usually learns something from his experiences, though the transfer of his new knowledge to a workable solution or the mitigation of a problem is easier said than done.

Benjamin Franklin once said, "Some people are weatherwise but most are otherwise." Since his time, more and more people have become weatherwise or at least concerned about the weather because the weather does affect the quality of their lives and their economic well being.

Probably the most generally recognized fact that was reemphasized by the drought is that water is both a limited and a renewable resource. This apparent dichotomy is mainly a matter of degree, but it is also related to changes in other factors in both time and space. Water may be limited by the short supply as evidenced by the small amounts of storage left in many reservoirs by the fall of 1977. Water in a few reservoirs was near the normal amount, and water in aquifers was still ample for the current needs, but it was limited because the means to deliver the water did not exist, or the cost to pump water from greater depths was excessive, or as in California enough baseload power needed to pump ground water or water in canals, was not available during the seasons of high demand. The rains and snow that came late in 1977 did renew the supply in reservoirs and brought some groundwater levels up. However, the aquifers where subsidence occurred will never be able to contain as much water as they did before the subsidence because the compaction of the materials in the aquifer has eliminated a significant amount of the pore space. In several areas the withdrawal of ground water exceeds the recharge; therefore, the water replenished just prolongs the time until other serious problems may develop.

Any plans for the future will not be very sound unless they are founded on a good data base and competent analyses and interpretations of the information. The quantity and quality of surface and ground waters as they occur from day to day must be determined in sufficient detail so that probabilities of occurrence of rare events and the risk involved may be estimated with more reliability. Also, because water data are collected only at selected sites, regional relations need improvement so that the data base can be extrapolated to any point of interest more reliably than at present. This is particularly true of low streamflows. Discharge measurements of low flows are made by the Geological Survey at gaging stations and numerous miscellaneous sites where a project is proposed to improve regional low-flow relations. There are many areas of the United States where little is known about ground-water conditions or where only reconnaissance level studies have been made. The growing population in arid and semi-arid areas has increased the demands for water in parts of the nation where development was not foreseen a few years ago and consequently increased the need for more water data.

Another important need for future planning is a better determination of water use. This is especially true in time of drought, and it is also important in long-term planning for future droughts. Efforts along this line have been made in the past (MacKichan, 1951; Murray and Reeves, 1977), and a new program has been started by the Geological Survey in cooperation with the States to obtain current data on water use. The National Research Council has proposed a study on planning, preparedness, and management in relation to droughts, and the role of water use data is a prominent part of the study. The quantification of water use will be the basis for analyses of trends and changing patterns in water use that in turn will improve plans for development of water resources.

Johnston (1978) presented another viewpoint on water use when he stated:

If per capita water usage in an area can be permanently cut by one-third through conservation and reclamation, then developers would have a powerful argument to justify more growth. More development, however, would cause other problems such as traffic congestion, smog, less open space and increased demands for tax-financed services such as schools, police and fire 
protection and welfare. And if Westerners learn to get by on less water by eliminating waste, the next time a drought comes the margin by which water consumption can be reduced without imposing real hardships may be dramatically lessened. If the water saved by conservation is put to use by others, the next drought could mean hardships that the reservoirs, the new wells and the water reclamation equipment will not be able to overcome.

Also, he could have pointed out that solutions to the problems he mentions would require more water.

Agencies at all levels of government found that they could cooperate during the drought to alleviate or solve drought induced problems within their mission and the legal and other constraints imposed upon them. In the instances when cooperation could not be accomplished, some reevaluation of policies, priorities, operating agreements, and legal aspects seems in order so that reaction to a drought crisis can be replaced by planned actions before a drought occurs. For example: Irrigators in Wisconsin claimed that though emergency drought relief programs were in effect, the delays in providing relief reduced the usefulness of the assistance. Also, they were concerned that a 30-day state-of-emergency period was too short a time considering the duration of the drought in 1976. The promised extension was for another 30 days, but it came after an interval of a month. Also, the U.S. General Accounting Office (1977) questioned whether existing water resource plans and programs adequately meet the competing demands for water uses.

Companies and municipalities supplying domestic water raised their rates to maintain their level of income while water sales were down because of rationing during the drought. At the end of the drought, part of the raise was commonly rescinded, but the increased rates may be the initial step toward the end of "cheap" water. One benefit of the water shortage is that people who looked upon water as an inexpensive resource, a "freebie" as one person expressed it, and one readily obtained are now concerned about the adequacy of the water supply and its worth in today's market. Usually the consumer who used more water paid a lower rate, but proponents of water conservation argue that the more water used, the higher the rate should be. A small step toward water conservation has occurred in Wisconsin where legislation has been introduced to amend the plumbing code to restrict flow rates to $3 \mathrm{gal} / \mathrm{min}$ regardless of pressure. The water situation has been compared to the circumstances relating to the change in the cost of energy in 1973. More changes in the pricing policies for water will probably occur in the future.

The recycling of water used by industry and by a few households seems to be here to stay. The degree to which recycling is developed depends, among other things, upon the attitude of the public toward the uses of recycled water, the elimination of health hazards, the costs of recycling equipment, the cost of fresh water, and the availability of fresh water. Currently, the prevailing view in relation to recycling in homes is that treatment at the source will be less expensive and safer than if it is done by nonprofessionals in the home.

There are those who contend that people who move into desert areas where the water supply is insufficient for their needs should not receive water from systems subsidized by the nation's taxpayers. One alternative for these people is to rely on desalinated water which is relatively expensive, but many people in the United States and in other countries do so now. The drought refocused attention on desalinization of seawater; however, its cost is about three to nine times the cost of present supplies. Furthermore massive growth in desalinization would require major expenditures of energy-another commodity increasingly in short supply.

A drought is a catalyst that makes the "have-nots" look toward the "haves" for supplies of additional water. The distinction between the two groups is usually relative and often nebulous, but nevertheless interest in interbasin transfers of water is renewed. Whether or not the United States can afford to build very large storage and distribution systems is a question to be settled in the future probably under different social and economic conditions than exist in 1978. The costs of even intrabasin transfers or exchanges of water are high, and many complex factors must be considered and integrated into a plan 
before a decision is made to proceed with or reject a project.

One approach to better management of the water resource is the conjunctive use of surface and ground water. Basically this technique involves the recharge of groundwater aquifers using surplus surface water in wet periods and the withdrawal of ground water to supplement surface supplies during dry periods. The natural recharge is augmented by artificial means which include injection wells where water is pumped into the aquifers, spreading basins that allow increased percolation into the aquifers, and dams that store flood waters so that the water can be released over an extended period of time to increase percolation through the streambed. The elimination of evaporation when water is stored underground is a big advantage over surface storage, but the energy needed to recover the water is becoming a more important factor in overall planning. Where the surface-water resources are highly developed to increase the basin yield in normal years, the flexibility of management and the amount of water in reserve are restricted during a drought, particularly a multiyear drought.

The legal complications of conjunctive use often prevent its implementation. Decisions, frequently by the courts, must be made regarding ownership of the water when underground, how the older surface-water rights relate to the surface water that has become ground water, and other questions that are peculiar to a given area. Times have changed; but someone claimed that up to not so long ago, more people had been killed in disputes over water or water rights than had been killed in lover's quarrels!

The United States Department of the Interior (1951) issued a report on the drought in the southwestern United States as of October 1951. The first recommendation made was that

... all state and local agencies be urged to initiate immediately the necessary action to establish effective controls over ground-water development and withdrawals in order to insure a stable agricultural economy in those areas that must depend entirely or in part on ground water as a source of irrigation water supply.
Unfortunately, little action, immediate or otherwise, followed this recommendation made 27 years ago. The drought of 1976-77 should provide new and stronger stimulus to implement this suggestion.

Another promising approach to water problems is recent enabling legislation in a few states that allows the formation of conservancy districts. These have the potential of controlling the use of water to provide more equitable distribution during dry periods and droughts. Because conservancy districts are relatively new and the law in all states is not the same, the effects of actions by the districts during the drought of 1976-77 were mixed-some successes, some defeats.

The dual problems of water as a user of energy and energy as a user of water will become more important in the near future. The transportation of water from a source to a point of use requires a considerable amount of energy. Power is needed to pump water from wells, and those pumps lifting water several hundred feet use large amounts of power. The huge pumps that lift water into the DeltaMendota Canal and the California Aqueduct and over the Tehachapi Mountains in California need large blocks of the less expensive baseload or off-peak power which is not as plentiful as it was. When water is used to generate hydroelectric power that is used to lift the same water into a canal, a loss of energy results, but the process is essential to move the water to where it is needed.

The development of new, but not necessarily different, sources of energy requires water whether the development is of coal in the northern Great Plains States, oil shale in Colorado and Utah, or nuclear plants or stream generating power plants wherever they may be. Water is used to make slurries to transport coal by pipeline, in the oil-shale extraction process, for rehabilitation and replanting of strip-mined areas, and for cooling in nuclear and steam plants. The volumes of water required are large enough to cause conflicts with existing uses and rights, and resolutions of these conflicts will be needed in the future.

The reduction of major or irreversible damage caused by a drought will require many different measures. The main objectives are to increase the water supply or reduce the use of it. A wide array of measures have been used, but not all are feasible or suitable in 
every case. Besides tailoring the measures to a specific area to alleviate drought conditions, the selection of the measures must be based also on the quantity and quality of the water and the importance of the supply locally, regionally and nationally.

Different agencies have different responsibilities relating to water most of which are complimentary, but some are conflicting. Also, different interests among the public such as the commercial, agricultural, environmental, development, and sportsmen's groups support or obstruct various measures according to the impact of the proposed measures upon the activities of the groups. To ease the immediate impacts of the drought of 1976-77, agencies and groups met and made compromises which worked. If cooperation occurs in the future, the outlook for diminshed waterrelated problems will be brighter.

The drought also highlighted the fact that an adequate water supply is no longer solely the concern of arid regions. Humid areas in the Pacific Northwest, the Southeast, and the Midwest had serious prob'ems; therefore, changes in the status quo may be expected that will affect the entire nation.

There have been a few attempts to plan and manage water on an integrated basis for an entire river basin. To do so involves land use planning also because of the close link between land and water. More of this type of an approach is needed in the future. This concept and others being tried may change the perceptions of the governments and the public about water resources. Water is limited as described previously, and it is not something that is part of a person's birthright.

To prepare properly for the future using any of the activities mentioned above, research and development are necessary. Though the data base has increased enormously in recent years and new techniques and instruments have been useful, there are still many unanswered questions. The inability to obtain the types of data required when and where they are needed is another serious problem. To overcome the shortcomings, viable research projects-both basic and applied-are needed.

Many aspects of water quality are not clearly understood, and some long-standing concepts have been challenged. A few examples: How can desalinization be improved, can reductions of oxygen in water be pre- vented or alleviated, what changes in the water resource are caused by urban runoff, is the chlorination of water really harmful to health? Research is needed before these and similar problems can be solved.

Better management plans to make the best use of the available water supply, better conservation practices such as trickle irrigation and no-till or shallow plowing of fields, and better instruments and equipment will depend to a large extent on the research efforts devoted to them.

More research is needed to develop and refine remote sensing to locate recharge areas and springs and to evaluate snowpacks and other sources of water. Satellite imagery has proven to be a highly useful way to obtain synoptic information, and aerial photography is a powerful tool when detailed studies are made.

Research and development are in progress in the fields of weather forecasting and weather modification. The National Oceanic and Atmospheric Administration anticipates that during the next 10 years they will have the capability to project month-by-month and season-to-season weather developments with much more skill than they do now. A National Academy of Science panel of scientists foresees serious climate changes beginning sometime in the next century. If the world increases its dependency on coal for energy, the panel expects more air pollution and a greenhouse effect that will warm the atmosphere, melt ice caps, raise the level of the oceans and flood coastal areas, and alter the patterns of atmospheric circulation. However, there are other scientists who do not believe this will happen. Both governmental agencies and private organizations are researching the physics related to weather modification, and they are conducting field tests and applying their state-of-the-art knowledge in a number of areas primarily in the 17 western States. The proponents claim successful operations in most of the areas. The legal problems relating to the results or even the anticipated results have not been resolved. See page 23 .

The Geological Survey is involved in research related to climate as it affects land and water resources (Smith, 1978). Investigations have been divided into five categories: (1) Present climate-related processes and indices that provide baseline data for climatic inter- 
pretation; (2) geologically short-term changes in climate: (3) geologically longer term climate changes; (4) the areal distribution of past climates; and (5) dating and correlation methods. A few of the projects in the first category involve measurements of streamflow, ground-water levels, glaciers, erosion rates, channel geometry, evaporation, lakes, and animal and plant communities; rainfall-runoff modeling, water chemistry, weathering, and soil formation. The intent of the research is to provide better bases for resource management and for estimating climate-related risks and hazards such as a drought.

Several studies have been made in which the water supplies at some future time have been estimated. The Water Resources Council reported (Nation's Business, 1977) that only the South Atlantic region, the Ohio River basin, and New England would be expected to have adequate water supplies by the year 2000 unless additional reservoirs are built and other steps taken to help nature provide the water that will be needed.

The water resources available to metropolitan areas are limited, and several routinely supply more water than they could during a drought (U.S. General Accounting Office, 1977). By the year 2000, 85 percent of the population may be living in metropolitan areas, an increase of about 10 percent. The drought in the Northeastern States during the 1960's affected several metropolitan areas; yet since then no major water supply projects have been built to serve the three most critical areas; Washingon, D.C., New York City, and the East Massachusetts-Rhode Island metropolitan areas. Water projects take many years to plan, authorize, design, and build; and because metropolitan areas must obtain water from outside the area, any project will infringe upon nearby communities and rural areas thereby raising numerous legal, political, and environmental problems.

Though most of the nation's population is served with safe drinking water by central water-supply systems, about 31 million people must rely on their own domestic supply, mostly from wells. There are also 6 million persons, primarily in remote areas and with low incomes, who have no running water in their dwellings. There are Federal programs to help improve water supply facilities in rural areas, but many small communities are faced with a water supply that is not sufficient in quantity or quality or both to maintain or improve the viability of the community.

The Comptroller General of the United States (1977) reported on the drought in California during 1976-77 and concluded that the State water plan shows that dependable water supplies will not provide for State needs through the year 2000, even if planned Federal, State, and local surface and ground-water projects are completed and if waste water is reclaimed and re-used. The State expects the deficit to be made up through the continued overdraft of ground water. If the overdraft in the eastern San Joaquin Valley is not rectified within the next 20 to 25 years by restricting ground-water use and importing surface water, more than 1 million acres of California's more productive agricultural land could be lost. This situation and others related to the drought imply that a re-examination of the State water plan in conjunction with the Federal government is desirable.

Many water and power projects in the Western States that had been deferred for various reasons are being reevaluated in relation to how they might alleviate drought conditions in the future and projected shortages of water and power.

The above examples briefly indicate some of the complexities associated with water resources and water supply. Part of the picture is not very encouraging. Though individuals, groups, and agencies are working and planning improvements to make more water of better quality available, apathy is apt to dominate the public's views during wet periods. Bond issues for local water developments have been defeated, and tax dollars for some projects acceptable to all parties involved have not been provided. Nace and Pluhowski (1965) stated, "Man is an optimist, and during periods of ample water supply, he tends to forget past adversities and acts as though the adversities cannot recur." It is difficult to think about and plan for drought conditions when it is raining.

The bright side of the picture shows the rapid development of techniques and abilities during the last 10 or 15 years. Large computers can now be used to help in more sophisticated analyses of larger areas so that the interactions of surface and ground waters and changes in quality can be estimated with 
more reliability than was possible just a few years ago. The data base is expanding and more scientists in fields directly related to water are working with professionals in the fields of planning, economics, legislation, etc., to develop better integrated solutions to water problems. The importance of water quality has been recognized as the controlling factor in many cases, and legislation and funds have been provided to improve water quality. These activities indicate that man has entered a renaissance with respect to water resources.

\section{SELECTED REFERENCES}

Barksdale, H. C., O'Bryan, Deric, and Schneider, W. J., 1966, Effect of drought on water resources in the northeast: U.S. Geological Survey Hydrologic Atlas 243.

Bensen, M. A., and Gardner, R. A., 1974, The 1971 drought in south Florida and its effect on the hydrologic system: U.S. Geological Survey Water Resources Investigations 1274,45 p.

Buchanan, T. J., and Gilbert, B. K., 1977, The drought, in Water spectrum, summer 1977: U.S. Department of the Army, p. 6-12.

California Department of Water Resources, 1976, The California drought-1976: California Department of Water Resources, 99 p.

1977a, Water Conditions in California: California Cooperative Snow Surveys Bulletins.

1977b, The California drought -1977 , an update: California Department of Water Resources, 150 p.

1977c, The continuing California drought: California Department of Water Resources, $138 \mathrm{p}$.

1978, The Sacramento Valley water use survey, 1977: California Department of Water Resources.

Columbia River Water Management Group, 1978, Columbia River water management report for water year 1977 , p. 45-55.

Committee on Fishery Operations, 1977, Special drought year operation for downstream fish migrants: Columbia River Water Management Group, 70 p.

Comptroller General of United States, 1977, California drought of 1976 and 1977-Extent, damage, and government response, 92 p.
Environmental Data Service, 1976, Climatological data, national summary, 1975: $\mathrm{Na}-$ tional Oceanic and Atmospheric Administration, v. 26 , no. 13,124 p.

Foehner, O. H., 1977, Weather modification-a major resource tool: in Proceedings Western Snow Conference, Albuquerque, New Mexico, April 18-21, 1977, p. 1-7.

Freeman, O. W., 1929, Evidence of prolonged droughts on the Columbia Plateau prior to white settlement: Monthly Weather Review, v. 57, June 1929, p. 250-251.

Gatewood, J. S., Wilson, Alfonso, Thomas, H. E., and Kister, L. R., 1964, General effects of drought on water resources of the southwest: U.S. Geological Survey Professional Paper 372-B, 53 p.

Griffith, E. L., 1978, Southern California's drought response program: Journal American Water Works Association, v. 70, no. 2, February 1978, p. 74-78.

Hoyt, J. C., 1936, Droughts of 1930-34: U.S. Geological Survey Water-Supply Paper 680, $103 \mathrm{p}$.

1938 , Drought of 1936 with discussion on the significance of drought in relation to climate: U.S. Geological Survey WaterSupply Paper 820, 60 p.

Johnston, David, 1978, Is the drought really over?: Sundancer Magazine, February 1978: Hughes Air West, v. 7, no. 2, p. 107.

Lappala, E. G., 1978, Quantitative hydrogeology of the upper Republican Natural Resources District, southwest Nebraska: U.S. Geological Survey Water Resources Investigations 78-38, $200 \mathrm{p}$.

Lofgren, B. E., 1977, Changes in aquifersystem properties with ground-water depletion: in Proceedings, 11th California Biennial Groundwater Conference, September 15-16, 1977, Fresno, California, p. 4868.

Mackichan, K. A., 1951, Estimated use of water in the United States-1950: U.S. Geological Survey Circular 115, 13 p.

Murray, C. R., and Reeves, E. B., 1977, Estimated use of water in the United States in 1975: U.S. Geological Survey Circular 765, 39 p.

Nace, R. L., and Pluhowski, E. J., 1965, Drought of the 1950 's with special reference to the Midcontinent: U.S. Geological Survey Water-Supply Paper 1804, 88 p. 
Nation's Business, 1977, Water: The next resource crisis?, September 1977 , p. 50-55.

Palmer, W. C., 1965, Meteorological drought: U.S. Weather Bureau Research Paper no. $45,58 \mathrm{p}$.

Palmer, W. C., and Denny, L. M., 1971, Drought bibliography: Environmental Data Service, National Oceanic and Atmospheric Administration, Technical Memorandum EDS 20, 233 p.

Robie, R. B., 197.8, California's program for dealing with the drought: Journal American Works Association, v. 70, no. 2, February 1978 , p. 64-68.

Sellers, W. D., 1960, Precipitation trends in Arizona and western New Mexico in Proceedings, Western Snow Conference, Santa Fe, New Mexico, p. 81-94.

Shelton, M. L., 1977, The 1976 and 1977 drought in California: Extent and severity: Weatherwise, v. 30, no. 4, August 1977, p. 139.

Smith, G. I., 1978, Climate variation and its effects on our land and water: U.S. Geological Survey Circular 776-B, 52 p.

Soil Conservation Service, 1977 a, Water supply outlook for Idaho $1977 \mathrm{~b}$, Water supply outlook for Nevada $1977 \mathrm{c}$, Water supply outlook for Oregon

ington 1977 , Water supply outlook for Wash-

1977 , Water supply outlook for western United States

State of Washington, 1977, Governor's ad hoc executive water emergency committee: Biweekly reports.

Subrahmanyam, V. P., 1967, Incidence and spread of continental drought: World Meterological Organization, International Hydrological Decade, Reports on WMO/IHD Projects, no. 2, Geneva, Switzerland.

Thomas, H. E., and others, 1963a, Effects of drought in central and south Texas: U.S. Geological Survey Professional Paper 372C, 31 p.

$1963 \mathrm{~b}$, Effects of drought in the Rio Grande basin: U.S. Geological Survey Professional Paper 372-D, $58 \mathrm{p}$.

$1963 \mathrm{c}$, Effects of drought in basins of interior drainage: U.S. Geological Survey Professional Paper 372-E, 50 p.

$1963 d$, Effects of drought in the Colorado River basin: U.S. Geological Survey Professional Paper 372-F, 51 p. 1963e, Effects of drought along Pacific Coast in California: U.S. Geological Survey Professional Paper 372-G, 25 p.

$1963 \mathrm{f}$, General summary of effects of the drought in the Southwest: U.S. Geological Survey Professional Paper 372$\mathrm{H}, 22 \mathrm{p}$.

Troxell, H. C., 1957, Water resources of Southern California with special reference to the drought of 1944-51: U.S. Geological Survey Water-Supply Paper 1366, 139 p.

Upper Mississippi River Basin Commission, 1977, Drought, dilemma, decisions: Proceeding of Symposium on drought in midAmerica, $162 \mathrm{p}$.

U.S. Department of Interior, 1951, Drought in southwestern United States as of October $1951,65 \mathrm{p}$.

U.S. Environmental Protection Agency, 1976, Quality criteria for water, Washington, U.S. Government Printing Office, 256 p.

U.S. General Accounting Office, 1977, Water resources planning, management, and development: What are the nation's water supply problems and issues, July 28, 1977.

Water Resources Council, 1966, Drought in northeastern United States, a third appraisal.

Wells, Wade, 1978, Fires producing "waterproof soils": Sediment Management Newsletter no. 3, Spring 1978, California Institute of Technology and Scripps Institute of Oceanography, p. 3.

Whipple, W., Jr., 1966, Regional drought frequency analysis: American Society Civil Engineers, Journal Irrigation and Drainage Division, v. 92 , no. IR2, June 1966 , p. 1131. 